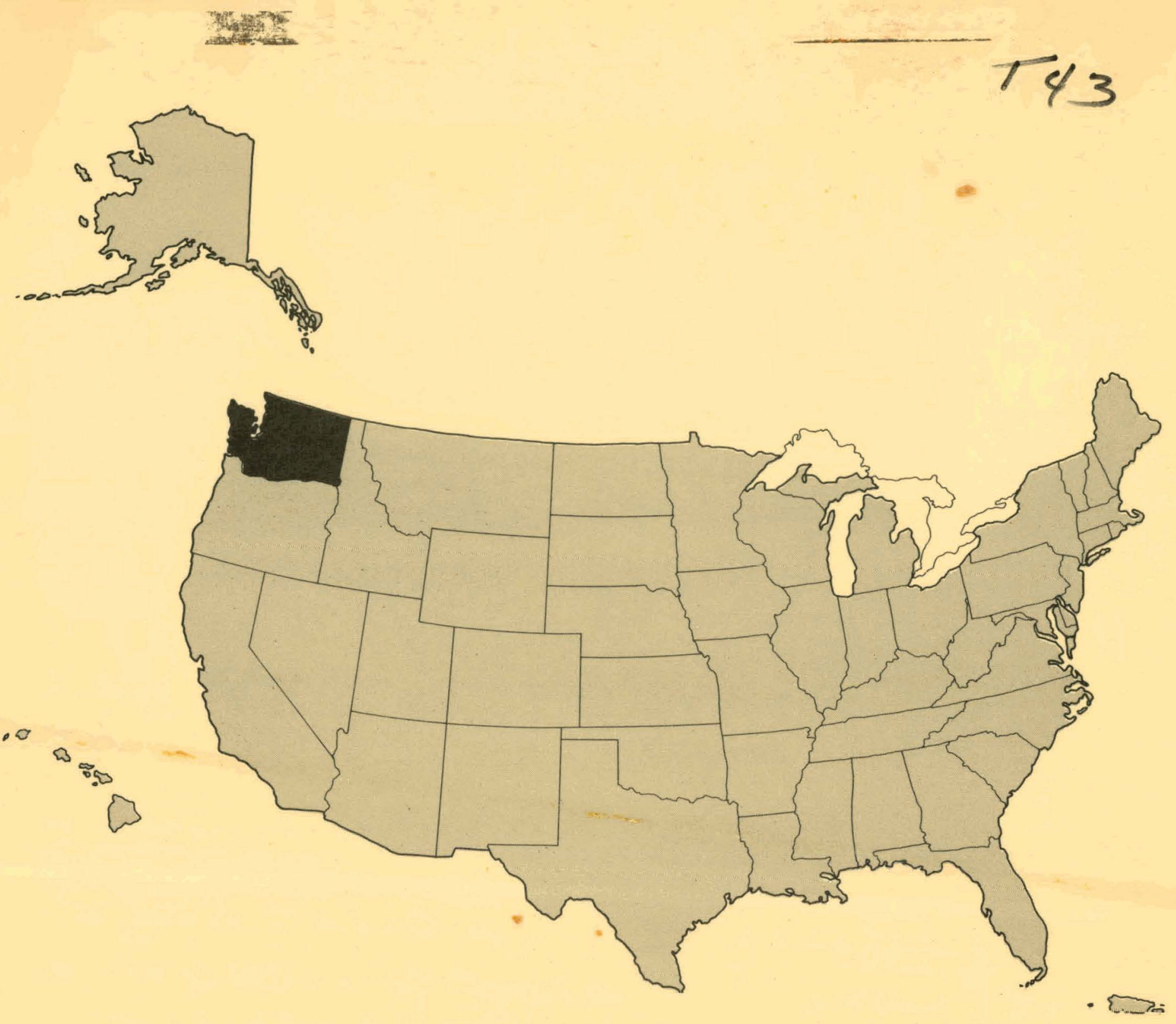

\title{
Washington State Briefing Book for Low-Level Radioactive MASTER Waste Management
}




\section{DISCLAIMER}

This report was prepared as an account of work sponsored by an agency of the United States Government. Neither the United States Government nor any agency Thereof, nor any of their employees, makes any warranty, express or implied, or assumes any legal liability or responsibility for the accuracy, completeness, or usefulness of any information, apparatus, product, or process disclosed, or represents that its use would not infringe privately owned rights. Reference herein to any specific commercial product, process, or service by trade name, trademark, manufacturer, or otherwise does not necessarily constitute or imply its endorsement, recommendation, or favoring by the United States Government or any agency thereof. The views and opinions of authors expressed herein do not necessarily state or reflect those of the United States Government or any agency thereof. 


\section{DISCLAIMER}

Portions of this document may be illegible in electronic image products. Images are produced from the best available original document. 


\title{
DOE/TS/OO1570-.T43
}

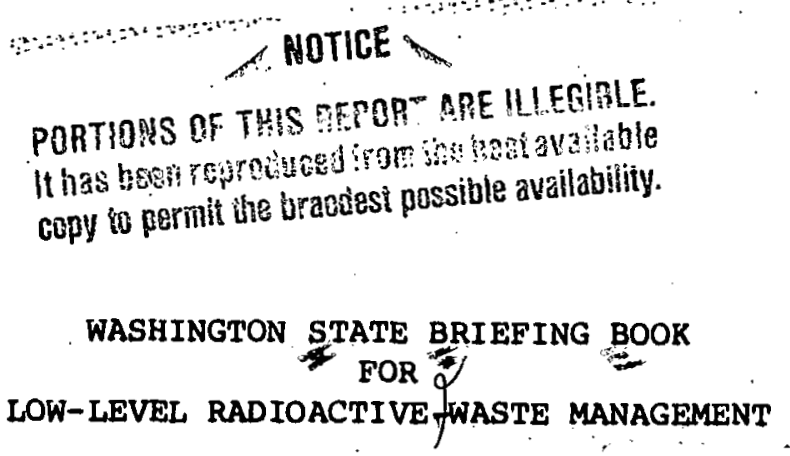

NUS $3635 \mathrm{C}$

DOE/ID/01570--T43

DE82 015271

Prepared for

EG\&G Idaho, Inc. under

subcontract No. $K-5108$

Prepared by

NUS Corporation

4 Research Place

Rockville, Maryland 20850

December 1980

This report was prepared as an account of work sponsored by the United States Government. Neither the United states nor the Department of Energy, nor any of their employees, nor any of their contractors, subcontractors, or their employees, makes any warranty, express or implied, or assumes any legal liability or responsibility for the accuracy, completeness, or usefulness of any information, apparatus, product, or process disclosed, or represents that its use would not infringe privately owned rights.

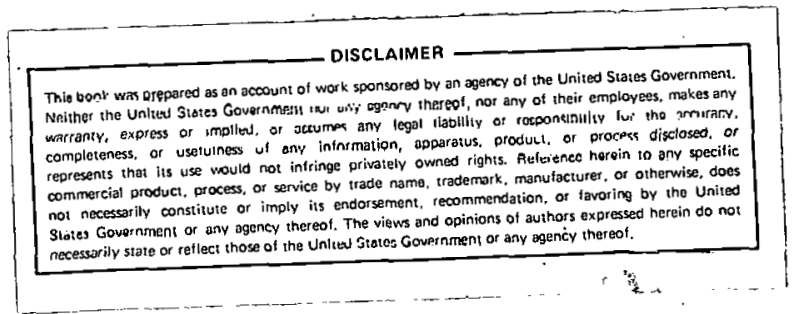

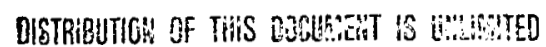


TABLE OF CONTENTS

Page

Title page

Table of Contents

List of Figures

iv

List of Tables

$\mathbf{v}$

\section{Section}

1. Introduction : 1-1

2. Overyiew of Low-Level Radioactive Waste Management 2-1

3. Demography 3-1

3.1 Location 3-1

3.2 Population 3-1

3.3 Economy 3-2

3.3.1 Major Business Sectors 3-2

3.3.2 Employment and Per Capita Income 3-7

3.3.3 Gross State Product. 3-7

3.4 Agrioulture 3- 3.

3.5 Schools, Hospitals, and National Laboratories 3-16

4. Governmental and Public Aspects 4-1

4.1 Major Political Parties 4-1

4.2 Congressional Representatives 4-1

4.3 State Government 4-2

4.3.1 Executive Branch 4-2

4.3.2 Legislative Branch 4-9

4.3.3 Judicial Branch 4-16

4.3.4 Statutory Regulations 4-17 
TABLE OF CONTENTS (concluded)

4.4 Federal Activities in the state of Washington 4-17

4.5 Interest Groups $\quad$ 4-17

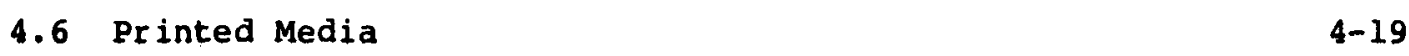

5. Survey Methodology 5-1

6. Use of Commercial Low-level Waste Disposal Facilities 6-1

6.1 Response to survey $6-1$

6.2 Sources of Shipped waste $\quad 6-2$

6.2.1 Distribution by Type of Facilities. $6-2$

Shipping Wastes

6.2.2 Origin of Radioactivity Resulting in . $6-2$ Shipped Waste

6.3 Volume of Shipped Waste $6-2$

6.4 Activity of Shipped waste $\quad$ 6-3

6.5 Physical Characteristics of Shipped Waste 6-3

ÄPPENDICES

A. Radioactive Material Licenses in the State of Washington A-l

B. State Laws and Regulations Apply to Radioactive Waste B-1 Management in Washington

C. Representative Newspaper Articles Related to Radiation C-l Issues and Radioarti ye Wasto Management 
3-1 Counties of the State of Washington 3-3

3-2 Standard Metropolitan Statistical Areas in Washington 3-4

3-3 Population Density by County: Washington, 1975 3-6

3-4 Percent of Gross Product by Industry: United States and 3-14 Washington, 1978

4-1 Washington Congressional Districts 4-7

4-2 List of State Agencies $4-10$

5-1 Survey Form $5-2$

5-2 Transmittal Letter for Survey Form 5-4

5-3 General Instructions 5-5

5-4 Form Used for Tabulation 5-6 


\section{LIST OF TABLES}

Table

Page

1-1 Commercial Shallow Land Burial sites 1-2

1-2 Total U.S. Waste Volumes Buried at Commercial 1-3.

Burial Sites (Cubic Meters)

2-1 Use of Commercial Low-level Waste Facilities 2-6

2-2 Disposal Practices Used for Low-Level Radioactive Wastes 2-7

2-3 Sources of Radioactivity Requiring Disposal 2-8

3-1 Standard Metropolitan Statistical Areas in the 3-5

State of Washington

3-2 Major Economic Activities in Washington by Cunney 3-8

3-3 U.S. and Washington Labor Force, 1976 and 1978 3-9

3-4 Per Capita Income in the U.S. and Washington for 3-9 Selected Years

3-5 Persons Living Below the Poverty Level in the U.S. and 3-9 Washington, 1969, 1975

3-6 Gross National Product, U.S. Employee Compensation 3-10 and Ratio of Product to Compensation, by Industry

3-7 Employee Compensation and Estimated Gross State 3-12 Product, by Industry, for Washington

3-8 Washington's Rank in the Nation's Agliculture 1978 3-15

4-1 Washington Members of the United States Congress 4-3

6-1 Response co Direct Mail'Survey 6-4

6-2 Type of Facilities Shipping Low-Level Waste 6-5

6-3 Origin of Radioactivity Resulting in Shipped Wastes 6-6

6-4 Volume of Shipped Waste 6-7

6-5 Projected Change in Volume of shipped Waste 6-8

6-6 Activity of Shipped wastes 6-9 
LIST OF TABLES (concluded)

\section{Table}

Page

6-7 Radionuclides in Shipped waste

6-10

$6-8$

Onsite Processing of Shipped Waste.

6-11

$6-9$

Shipping Container Used

$6-12$

$6-10$

Physical Form of Shipped Waste

$6-13$ 


\section{INTRODUCTION}

This Washington State Briefing Book for Low-Level Radioactive Waste Management has been prepared to assist in the orderly planning and implementation of providing adequate safe low-level radioactive waste disposal facilities. The Washington State Briefing Book is one of a series of briefing books being prepared that will provide background information of waste management practices in all states.

of six commercial low-level radioactive waste disposal sites that have operated within the United States (see Table 1-1), only three are currently accepting additional wastes. Of these three, two sites have been closed intermittently because of various irregularities in disposal and shipping operations. (1) Table 1-2 presents the total waste volumes that have been disposed of at commercial sites during the period 1962 through 1979. In 1979, approximately 80 percent of the wastes were shipped to the South Carolina site.

Projections of total national low-level radioactive waste generation and capacity of existing commercial disposal facilities indicate that if no change in present practices or trends occur, the current disposal sites could be filled by the mid1990s. However, recent proposed limitations of yearly burial quantities to be accepted by disposal sites located in South Carolina and Washington state will reduce the availability of burial space. South Carolina's limit on waste receipts will be reduced to 100,000 cubic feet per month by October 1981 and a Washington State initiative will restrict use of the Richland commercial disposal site after July 1, 1.981. Therefore, it is possible that by the mid-1980s there would be more waste volume generated per year than cuuld be buried. (1)

Section 2 of this Briefing Book presents an overview of past and present low-level radioactive waste management practices within the state of washington. Section 3 identifies those demographic and economic factors and trends that affect or can be related to the quantity and nature of low-level radioactive wastes within the State 
TABLE 1-1

COMMERCIAL SHALLOW LAND BURIAL SITES ${ }^{(1)}$

\begin{tabular}{|c|c|c|c|c|}
\hline Location & $\begin{array}{c}\text { Year first } \\
\text { licensed }\end{array}$ & $\begin{array}{l}\text { Site } \\
\text { operator } \\
\end{array}$ & $\begin{array}{l}\text { Licensing } \\
\text { authority }\end{array}$ & $\begin{array}{c}\text { Year } \\
\text { closed }\end{array}$ \\
\hline Maxey Flats, ky. & 1962 & $\begin{array}{l}\text { Nuclear } \\
\text { Engineer ing } \\
\text { Company }\end{array}$ & State & 1977 \\
\hline Beatty, Nev. & 1962 & $\begin{array}{l}\text { Nuclear } \\
\text { Company }\end{array}$ & State & Open \\
\hline Sheffield, Ill. & 1967 & $\begin{array}{l}\text { Nuclear } \\
\text { Engineer ing } \\
\text { Company }\end{array}$ & NRC & 1978 \\
\hline Richland, Wash. & 1965 & $\begin{array}{l}\text { Nuclear } \\
\text { Engineering } \\
\text { Company }\end{array}$ & $\begin{array}{c}\text { State } \\
\text { and } \\
\text { NRC }\end{array}$ & Open \\
\hline Barnwell, S.C. & 1971 & $\begin{array}{l}\text { Chem-Nuclear } \\
\text { Systems, Inc. }\end{array}$ & $\begin{array}{l}\text { State } \\
\text { and } \\
\text { NRC }\end{array}$ & Open \\
\hline West Valley, N.Y. & 1963 & $\begin{array}{l}\text { Nuclear Fuel } \\
\text { Services }\end{array}$ & $\begin{array}{c}\text { State } \\
\text { and } \\
\text { NRC }\end{array}$ & 1975 \\
\hline
\end{tabular}


TABLE $1-2$

TOTAL U.S. WASTE VOLUME BURIED AT COMMERCIAL BURIAL SITES (CUBIC METERS)

\begin{tabular}{|c|c|c|c|c|c|c|c|}
\hline \multirow[b]{2}{*}{ Year } & \multicolumn{6}{|c|}{ Burial site } & \multirow{2}{*}{$\begin{array}{c}\text { National } \\
\text { annual } \\
\text { total }\end{array}$} \\
\hline & Kentucky & Nevada & $\begin{array}{c}\text { South } \\
\text { Carolina }\end{array}$ & Illinois & $\begin{array}{l}\text { New } \\
\text { York } \\
\end{array}$ & Washington & \\
\hline 1962 & - & 1,861 . & - & - & - & - & 1,861 \\
\hline 1963 & 2,206 & 3,512 & - & - & 522 & - & 6,240 \\
\hline $196 \dot{4}$ & 3,872 & 2,836 & - & - & 6,388 & - & 13,096 \\
\hline 1965 & 5,751 & 1,988 & - & - & 4,717 & 668 & 13,124 \\
\hline 1966 & 5,556 & 3,533 & - & - & 4,697 & 2,402 & 16,188 \\
\hline 1967 & 7,820 & 3,206 & - & 2,527 & 4,946 & 870 & 19,369 \\
\hline 1968 & 8,177 & 3,576 & - & 2,713 & 4,505 & 669 & 19,640 \\
\hline 1969 & 10,353 & 4,282 & - & 2,012 & 4,274 & 438 & 21,359 \\
\hline 1970 & 12,520 & 4,131 & - & 2,825 & 5,096 & 423 & 24,995 \\
\hline 1971 & 13,171 & 3,584 & 1,171 & 4,430 & 6,362 & 584 & 29,302 \\
\hline 1972 & 15,577 & 4,301 & 3,757 & 5,956 & 7,054 & 654 & 37,299 \\
\hline 1973 & 10.072 & 4,076 & 15,839 & 8,524 & 7,497 & 1,033 & 47,041 \\
\hline 1974 & 8,897 & 4,103 & 18,244 & 12,373 & 8,574 & 1,411 & 53,602 \\
\hline 1975 & 17,109 & 4,943 & 18,072 & 14,116 & $1,889 *$ & 1,500 & 57,629 \\
\hline 1976 & 13,783 & 3,864 & 40,227 & 13,480 & * & 2,867 & 74,221 \\
\hline 1977 & $423 * \star$ & 4,742 & $46,563^{\circ}$ & 17,643 & * & $2,7.18$ & 72,089 \\
\hline 1978 & ** & 8,827 & 61,566 & $102 * * *$ & * & 7,422 & 77,917 \\
\hline $1979^{(2)}$ & $\star *$ & 6,491 & 63,433 & $\star \star \star \star$ & * & 9,980 & 79,914 \\
\hline Total & 135,287 & 73,856 & 268,882 & 86,701 & 66,521 & 33,639 & 664,886 \\
\hline
\end{tabular}

*Receipt and burial of wastes were suspended by Nuclear Fuel Services on 3/11/75.

**Receipt and burial of wastes were suspended on $12 / 27 / 77$.

$\star \star \star$ Receipt and burial of wastes were suspended on $4 / 8 / 78$. 
of Washington. Section 4 presents an overview of Washington's state government and identifies the government institutions and agencies with statutory or other responsibilities affecting the generation, handling, and disposal of radioactive wastes within the state. The identities and attitudes of state officials and other organizations impinging on this issue are presented in the text and, where possible, in available representative print media. Section 5 presents the methodology employed for conducting a direct mail survey of radioactive material licensees within the state to obtain basic information on disposal practices. The results of this survey are presented in Section 6 for that information dealing with wastes shipped to commercial disposal facilities. 


\section{REFERENCE}

1. William F. Holcomb, Inventory (1962-1978) and Projections (to 2000) of Shallow Land Burial of Radioactive Wastes at Commercial Sites: An Update, Nuclear Safety, Vol. 21, No. 3, May-June 1980.

2. NUS Corporation, The 1979 State-by-State Assessment of Low-Level Radioactive Wastes Shipped to Commercial Burial Grounds, NUS 3440, Revision 1, November 1980. 


\section{OVERVIEW OF LOW-LEVEL RADIOACTIVE WASTE MANAGEMENT}

Historically, the generation of low-level radioactive waste and the requisite disposal practices of licensees have received little focus from regulatory agencies, interest groups, and the facilities themselves. These wastes, including their creation and environmental impact, were judged to be less than paramount in light of the waste volumes and activities produced by irradiated reactor fuel and other high-level sources. Although commercial nuclear power reactors contribute a significant portion of low-level radioactive waste, other major catagories of waste generators include medical, educational, and industrial facilities.

The State of Washington is an Agreement State whereby all radioactive material licenses and waste disposal practices are under the conditions and regulations established by the state government. The specific controls and operational criteria follow, at minimum, those instituted by the federal government.

There are presently no operational commercial power reactors located within the State of Washington. The Washington Public Power supply system has five nuclear units scheduled for commercial operation within ten to twelve years. Two additional reactors of joint utility ownership, Skagit 1 and 2 , are scheduled for operation in 1987 and 1989, respectively.

The Hanford Reservation, initiated in 1944, is a major U.S. Government facility encompassing 570 square miles in the southeastern part of washington. The facility is composed of a variety of nuclear installations, including a number of commercially owned power reactors under construction, weapons program related installations, engineerjing and research facilities, and the Richland low-level radioactive waste burial site. $(1,2)$

The Hanford Reservation is divided into five major areas. The 100 area is in the north and includes the plutonium production reactors. The 200 area is in about the center of the reservation and is the location for all fuel and waste processing and most waste storage. The 300 area in the south contains research facilities and a fuel fabrication plant. The 400 area is the site of the fast flux test reactor 
under construction. The 600 area refers to the thousands of acres not included in the other four axeas. $(1,2)$

Wastes generated by the Department of Energy facilities at Hanford can be categorized as high level, intermediate level, and low level. Most of these wastes are stored or disposed of in the 200 area. Two types of low-level radioactive waste are generated in the 200 area at Hanford: liquid wastes, such as cooling water and steam condensates; and solid wastes, such as tools, clothing, and laboratory supplies. The liquid wastes are discharged to 30 surface ponds and ditches, while solid wastes are buried within the 200 area. $(1,2)$

A variety of trench designs, packaging practices, and backfilling alternatives have been employed at Hanford since operations began. The specific parameters used depend on the available technology, waste volumes, and transuranic content of the wastes. As of April 1979, the Hanford site contained 7.16 million cubic feet of buried low-level radioactive waste. $(1,2)$

The Richland low-level radioactive waste burial site is a commercial facility located in an arid area approximately 25 miles north of Richland. The site is operated by the Nuclear Engineering Company on federal land which is leased to the State of Washington and subleased to Nuclear Engineering Company. Lucated on the Department of Energy Hanford Reservation, the site has received approximately 1.2 million cubic feet (to January 1980) of low-level radioactive waste making it one of the smallest (volume) commercial burial sites, $(1,2,3)$

Burial trenches at Richland are approximately 153 meters in length, 6 to 12 meters deep, and 18 meters wide. Nuclear Engineering Company anticipates the lengthening of trenches to 240 meters. $(1,2)$

The trenches are constructed with a bulldozer and a crane equipped with a dragline. No measures are taken at this site to collect trench drainage or to divert surface run-off. One trench is opended at a time to its full length. Waste drums and packages are dumped randomly into the trenches. Bulk liquid wastes are stored in underground tanks, and evaporated and solidifed prior to burial. $(1,2)$ 
Backfilling at the Richland site generally occurs on a daily basis About 1.2 meters of soil is placed on top of the wastes during this backfilling. No further. capping or trench finishing is done at this site due to the low precipitation there (approximately 7.6 inches/year). $(1,2)$

The Puget Sound Naval Shipyard, located in Bremerton, Washington, is a support facility for U.S. Naval nuclear-powered ships. Since no solid radioactive waste materials have been dumped at sea since 1970, the waste generated at this facility (approximately 85 cubic meters in 1979) is disposed of by shipment to burial sites licensed by the U.S. Nuclear Regulatory Commission or a state under agreement with the U.S. Nuclear Regulatory Commission. (4)

Throughout the state, prior to the late 1960s and early 1970s, low-level radioactive waste disposal practices typically consisted of onsite storage. In accordance with existing federal regulations, wastes were generally stored in above-ground buildings or buried in shallow trenches. Present trends in waste disposal include onsite storage and eventual release to sewer systems and combination with common refuse after appropriate decay to exempt concentrations. Exempt concentrations, at minimum, follow parameters outlined in the Code of Federal Regulations, Section. 10, part 20 .

The use of radioisotopes in medical diagnostic and therapeutic applications has increased as a result of relatively recent new applications and techniques in the medical field. Due to the short half-life of nuclides normally used for these purposes, the decay and release disposal method is frequently practiced. Other major facilities often select this mode of low-level radioactive waste disposal, if this option is feasible. As the availability of commercial low-level waste disposal facilities berome limited and economically prohibitive parameters impact the shipment of low-level radioactive waste, onsite decay is practiced with increased incidence.

The economics of waste shipment to distant repositories is dictating an efficient management program with regard to volumes generated by each facility. Trends by generator facilities appear to be channeled towards volume reduction. Evaluations are ongoing by numerous facilities to effectively reduce the volume and subsequently the number of requisite annual shipments of waste. These methods include the 
application of compaction, liquid evaporation, and waste solidification and incineration.

A total of 310 radioactive material licenses are in effect in Washington. Information on disposal practices was solicited from each license holder by a written questionnaire (see section 5.0). Appendix A presents the name and address of each license holder, the degree of response to the questionnaire, the type of facility, and whether they ship waste to a commercial disposal site. The degree of response was classified as follows:

$N$ indicates that no response to the written questionnaire was reseivod.

1 indicates the licensee did respond and provided all appropriate information.

2 indicates the licensee did respond but provided only information on type of facility, disposal method, and quantity of waste.

3 indicates the licensee did respond but provided only information on type of facility and disposal method.

The type of facility was classified as either Medical, Educational, Industrial, Power Reactor, or Governmental according to Part 1 of the survey form shown in Figure 5-4. It should be nnted that the Modical elassifleation includes both medical education facilties and governmental medical facilities, that the Educational classification excludes medical education facilities, and that the Governmental classification excludes both medical and educational facilities. A service unit, such as a la'joratory, was classified according to the type of facility to which it provides the service. In addition to these license holders, two government facilities (Hanford Reservation and Puget Sound Naval Shipyard) are included in the tabulation. Data for these facilities are included in all tabulations; however, these data were obtained from existing published sources rather than from the survey.

of the 312 radioactive material users, contact was made with 169, of which 20 indicated they ship waste to commercial disposal facilities. Table 2-1 presents a 
breakdown of license holders by type of facility, response to questionnaire, and number of facilities using commercial disposal facilities. The "percent of all respondents" was calculated as the number of respondents shipping waste divided by the total number of respondents times 100. The "percent of facility" respondents was calculated as the number of respondents shipping waste divided by the total number of respondents in a facility classification times 100.

Table 2-2 presents the waste disposal practices employed, including disposal. method other than shipment to commercial disposal facilities. In this table, the total of "number using" exceeds the total number of respondents due to use of several disposal practices by some facilities. It is believed that many facilities reported only the major disposal method used rather than all methods used and the data should be viewed with this qualification in mind. The "percent of all respondents" value was calculated as the number of respondents in a "type of facility" classification reporting use of a method divided by the total number of respondents times 100 .

Table 2-3 presents the source of the radioactivity which eventually requires use of some disposal method. 
TABLE 2-1

USÉ OF CCMMERCIA LOW-LEVEL WASTE FACILITIES

\begin{tabular}{|c|c|c|c|c|c|c|}
\hline \multirow[b]{2}{*}{$\begin{array}{c}\text { Type } \\
\text { of } \\
\text { facĩlity }\end{array}$} & \multirow[b]{2}{*}{$\begin{array}{l}\text { Numbez } \\
\text { of } \\
\text { licensees }\end{array}$} & \multirow[b]{2}{*}{$\begin{array}{c}\text { Number } \\
\text { of } \\
\text { respondents }\end{array}$} & \multirow[b]{2}{*}{$\begin{array}{l}\text { Percent } \\
\text { response }\end{array}$} & \multicolumn{3}{|c|}{ Respondents using a commercial facility } \\
\hline & & & & Number & $\begin{array}{l}\text { Percent } \\
\text { of all } \\
\text { respondents }\end{array}$ & $\begin{array}{l}\text { Percent } \\
\text { of facility } \\
\text { respondents }\end{array}$ \\
\hline Medical & 108 & 54 & 50.0 & 6 & 3.6 & 11.1 \\
\hline Educational & 21 & 13 & 61.9 & 5 & 3.0 & 38.5 \\
\hline Industrial & 139 & 73 & 52.5 & 7 & 4.1 & 9.6 \\
\hline Power Reactor & 0 & 0 & - & - & - & - \\
\hline Governmental & 39 & 29 & 74.4 & 2 & 1.2 & 6.9 \\
\hline Unkncwn & 5 & - & - & - & - & - \\
\hline TOTAL & 312 & 169 & 54.2 & 20 & 11.8 & - \\
\hline
\end{tabular}


TABLE 2-2

DISPOSAL PRACTICES USED FOR LOW-LEVEL RADIOACTIVE WASTES

\begin{tabular}{|c|c|c|c|c|c|c|c|c|c|c|c|c|c|c|c|c|c|}
\hline \multirow[b]{2}{*}{$\begin{array}{c}\text { Type } \\
\text { of } \\
\text { Pacility }\end{array}$} & \multirow[b]{2}{*}{$\begin{array}{l}\text { Number } \\
\text { of } \\
\text { re spondenta }\end{array}$} & \multicolumn{2}{|c|}{$\begin{array}{l}\text { Ship tc } \\
\text { Commerci,al } \\
\text { Reposito:y }\end{array}$} & \multicolumn{2}{|c|}{$\begin{array}{l}\text { Release to } \\
\text { Sewer }\end{array}$} & \multicolumn{2}{|c|}{$\begin{array}{l}\text { Combine with } \\
\text { Refuse . }\end{array}$} & \multicolumn{2}{|c|}{$\begin{array}{l}\text { Vent to } \\
\text { Atomsphere }\end{array}$} & \multicolumn{2}{|c|}{$\begin{array}{l}\text { Return to } \\
\text { Vendor }\end{array}$} & \multicolumn{2}{|c|}{$\begin{array}{l}\text { Distribute in } \\
\text { Product Form }\end{array}$} & \multicolumn{2}{|c|}{$\begin{array}{l}\text { No Maste } \\
\text { Generated }\end{array}$} & \multicolumn{2}{|c|}{$\begin{array}{l}\text { Bury } \\
\text { on site }\end{array}$} \\
\hline & & $\underset{\text { Number }}{\text { Uuing }}$ & $\begin{array}{l}\text { Percent } \\
\text { of all } \\
\text { respon- } \\
\text { dents }\end{array}$ & $\begin{array}{c}\text { Number } \\
\text { using }\end{array}$ & $\begin{array}{l}\text { Percent } \\
\text { of all } \\
\text { respon- } \\
\text { dents }\end{array}$ & $\begin{array}{l}\text { Number* } \\
\text { using }\end{array}$ & $\begin{array}{l}\text { Percent } \\
\text { of all } \\
\text { respon- } \\
\text { dents }\end{array}$ & $\begin{array}{c}\text { Number } \\
\text { uaing }\end{array}$ & $\begin{array}{l}\text { Percent } \\
\text { of all } \\
\text { respon- } \\
\text { dents }\end{array}$ & $\begin{array}{c}\text { Number* } \\
\text { using }\end{array}$ & $\begin{array}{l}\text { Percent } \\
\text { of all } \\
\text { respon- } \\
\text { dents }\end{array}$ & $\begin{array}{c}\text { Number } \\
\text { using }\end{array}$ & $\begin{array}{l}\text { Percent } \\
\text { of all } \\
\text { respon- } \\
\text { dents }\end{array}$ & $\begin{array}{c}\text { Number: } \\
\text { using }\end{array}$ & $\begin{array}{l}\text { Percent } \\
\text { of all } \\
\text { respon- } \\
\text { dents }\end{array}$ & $\begin{array}{l}\text { Number* } \\
\text { using }\end{array}$ & $\begin{array}{l}\text { Percent } \\
\text { of all } \\
\text { respon- } \\
\text { dents }\end{array}$ \\
\hline Medical & 54 & 6 & 3.6 & 27 & 100 & 29 & 17.2 & 2 & 1.2 & 16 & 9.5 & 0 & 0.0 & 13 & 7.7 & 1 & 0.6 \\
\hline Educatlonal & 13 & 5 & 3.0 & 1 & 0.6 & 1 & 0.6 & 0 & 0.0 & 4 & 2.4 & 0 & 0.0 & 4 & 2.4 & 1 & 0.6 \\
\hline Industrial & 73 & 7 & 4.1 & 3 & 1.8 & 2 & 1.2 & 0 & 0.0 & 28 & 26.6 & 1 & 0.6 & 35 & 20.7 & 1 & 0.6 \\
\hline Power Reactor & 0 & - & - & - & - & - & - & - & - & - & - & - & - & - & - & - & - \\
\hline covernmental & 29 & 2 & 2.2 & D & 0.0 & 1 & 0.6 & 1 & 0.6 & 6 & 3.6 & 0 & 0.0 & 19 & 11.2 & 1 & 0.6 \\
\hline Tomal & 169 & 20 & $1 \div .8$ & 31 & 18.3 & 33 & 19.5 & 3 & 1.8 & 54 & 32.0 & 1 & 0.6 & 71 & 12.0 & 4 & 2.4 \\
\hline
\end{tabular}

The total of "number using" exceeds the total number of respondents due to use of several practices at each facility 
TABLE 2-3

SOURC:S OF RADIOACTIVITY REQUIRING DISPOSAL

\begin{tabular}{|c|c|c|c|c|c|c|c|c|c|c|c|c|c|}
\hline \multirow[b]{2}{*}{$\begin{array}{c}\text { Type } \\
\text { of } \\
\text { facility }\end{array}$} & \multirow[b]{2}{*}{$\begin{array}{c}\text { Number } \\
\text { of } \\
\text { respondents }\end{array}$} & \multicolumn{2}{|c|}{$\begin{array}{l}\text { Muclear } \\
\text { recctor }\end{array}$} & \multicolumn{2}{|c|}{$\begin{array}{l}\text { Sealed } \\
\text { sources }\end{array}$} & \multicolumn{2}{|c|}{$\begin{array}{l}\text { Unsealed } \\
\text { radioactive } \\
\text { material }\end{array}$} & \multicolumn{2}{|c|}{ Dres } & \multicolumn{2}{|c|}{$\begin{array}{l}\text { Neutron } \\
\text { generator }\end{array}$} & \multicolumn{2}{|c|}{ Cyclotron } \\
\hline & & $\begin{array}{c}\text { Number } \\
\text { of } \\
\text { sources }\end{array}$ & $\begin{array}{l}\text { Percent } \\
\text { of all } \\
\text { respon- } \\
\text { dents }\end{array}$ & $\begin{array}{l}\text { Number } \\
\text { of } \\
\text { scurces }\end{array}$ & $\begin{array}{l}\text { Percent } \\
\text { of all } \\
\text { respon- } \\
\text { dents }\end{array}$ & $\begin{array}{l}\text { Number } \\
\text { of } \\
\text { sources }\end{array}$ & $\begin{array}{l}\text { Percent } \\
\text { of all } \\
\text { respon- } \\
\text { dents }\end{array}$ & $\begin{array}{l}\text { Number } \\
\text { of } \\
\text { sources* }\end{array}$ & $\begin{array}{l}\text { Percent } \\
\text { of all } \\
\text { respon- } \\
\text { dents }\end{array}$ & $\begin{array}{l}\text { Number } \\
\text { of } \\
\text { sources* }\end{array}$ & $\begin{array}{l}\text { Percent } \\
\text { of all } \\
\text { respon- } \\
\text { dents }\end{array}$ & $\begin{array}{l}\text { Number } \\
\text { of } \\
\text { sources* }\end{array}$ & $\begin{array}{l}\text { Percent } \\
\text { of all } \\
\text { respon- } \\
\text { dents }\end{array}$ \\
\hline Medical & 13 & 0 & 0.0 & 4 & 11.1 & 10 & 27.8 & 0 & 0.0 & 0 & 0.0 & 0 & 0.0 \\
\hline Educational & 5 & 1 & 2.8 & 1 & 2.8 & 4 & 11.1 & $0^{\circ}$ & 0.0 & 1 & 2.8 & 0 & 0.0 \\
\hline Industr $:$ al & 14 & 0 & 0.0 & 6 & $16 .:$ & 8 & 22.2 & 1 & 2.8 & 0 & 0.0 & 0 & 0.0 \\
\hline Power Reactor & 0 & - & - & - & - & - & - & - & - & - & - & - & - \\
\hline Governmental & 4 & $\cdot 2$ & 5.6 & 2 & 5.6 & 2 & 5.6 & 0 & 0.0 & 1 & 2.8 & 1 & 2.8 \\
\hline TOTAL & 36 & 3 & 8.3 & 13 & 36.1 & 24 & 66.7 & 1 & 2.8 & 2 & 5.6 & 1 & 2.8 \\
\hline
\end{tabular}

"The total of "number of sources" exczeds the total number of respondents due to facilities generating waste from several sources 
REFERENCES

1. NuS Corporation, Status of Low Level Radioactive waste Burial in the United States and Canada Environmental Monitoring Practices, NUS-3508, 1980.

2. U.S. Energy Research and Development Administration, Final Environmental Impact Statement - Waste Management Operations Hanford Reservation, ERDA1538, December 1975.

3. Nus Corporation, The 1979 State-by-State Assessment of Low-Level Radioactive Waste shipped to Commercial Burial Grounds, NUS 3440, Revision 1, November 1980 .

4. Department of the Navy, Environmental Monitoring and Disposal of Radioactive Wastes From U.S. Naval Nuclear Powered Ships and Their support Facilities, NT80-1, March 1980. 


\section{DEMOGRAPHY}

This section identifies those demographic and economic factors and trends that affect. or can be related to the quantity and nature of low-level radioactive wastes within the State of Washington, to assist with an assessment of the state as a potential producer of radioactive wastes. It also identifies those institutions, including hospitals, colleges, universities, and national laboratories, that are major users of radionuclides that may ultimately be radioactive wastes.

\subsection{LOCATION}

Washington is one of the northwestern coastal states of the United States. It is bounded on the north by the Canadian province of British Columbia and the Strait of de Fuca; on the east by the State of Idaho; on the south by the State of Oregon and the Columbia River; and on the west by the Pacific Ocean.

\subsection{POPULATION}

Population trends offer a broad-gauge measure of isotope utilization in medicine, educational and research activities, and industry. A trend revealing an increase in a state's population may imply increasing isotope use and in turn, waste generation.

Washington ranks as the twenty-first most populous state in the nation and had a population density of approximately 53 persons per square mile in $1975 .(1,2)$ The state's 1977 population of 3,681,000 persons represents a 7.9 percent increase over the 1970 population of 3,413,244 persons. In 1978, Washington's population totaled $3,774,000$ persons, or an annual increase of 0.25 percent. Natural population increases, accompanied by an inmigration of persons, were responsible for Washington's population growth. Between 1970 and 1977, there were 379,000 births as compared to 218,000 deaths. The state also experienced a net inmigration of 3.1 percent during the 7-year time period, which shows a greater inmigration of persons than outmigration. In 1977, the birth rate was 15.6 births per 1,000 persons, or approximately 57,237 births in contrast to 29,831 deaths or a mortality rate of 8.2 deaths per 1,000. In 1978, the state's birth rate was 15.5 births per 1,000 and the 
death rate was 8.1 per $1,000 .(3,4,5)$ (The 1978 figure represents a provisional sample of all deaths in Washington. A final figure is currently unavailable.)

Washington's major population centers are the state's six Standard Metropolitan Statistical Areas (SMSA) of Portland; Richland-Kennewick-Pasco; Seattle-Everett; Spokane; Tacoma; and Yakima. The population of these areas comprised 71.1 percent of the state's total population in 1978. Of the six SMSAs, the largest is the Seattle-Everett SMSA with a 1978 population of 1,467,600 persons and RichlandKennewick-Pasco is the smallest SMSA with a 1978 population of 128,000 persons. Between 1970 and 1977, all the SMSAs underwent population increases. Of these, the Portland SMSA increased the most $(28.3$ percent) and the seattle-Everett SMSA increased the least $(0.9$ percent). (3) Figures $3-1$ and $3-2$ depict the location of Washington's counties and SMSAs. Table 3-1 1ists the 1970, 1977, and 1978 population of the SMSAs, and Figure 3-3 presents the state's 1975 population density.

Washington's population, is expected to increase. The projected population of 4,834,100 persons in 1990 will represent a 20.0 percent increase over the 1980 population of 4,031,000 persons. It is further estimated that between 1990 and the year 2000 , the population will increase 10.0 percent and reach 5,333,300 persons by the year 2000 . $^{(6)}$

\subsection{ECONOMY}

\subsubsection{Major Business Sectors}

Washington's economy is basically built upon forestry, agriculture, and hydroelectricity. Although virgin forests have been largely depleted, much forest wealth remains ary is now utilized on a sustained yield basis. Washington's agriculture is quite diversified, producing wheat and other field crops, horticultural products, livestock, poultry, dairy products, and herbs and seeds. With the development of hydroelectricty, the electrochemical and electrometallurigloal industies have been attracted to the state, most notably the aluminum smelting and refining business. Another major sector in the state's economy is the industry and employment associated with the commercial aircraft and aerospace industry. overall, Washington's major economic sectors are manufacturing, retail trade, 
FIGURE 3-1

COUNTIES OF THE STATE OF WASHINGTON (3)

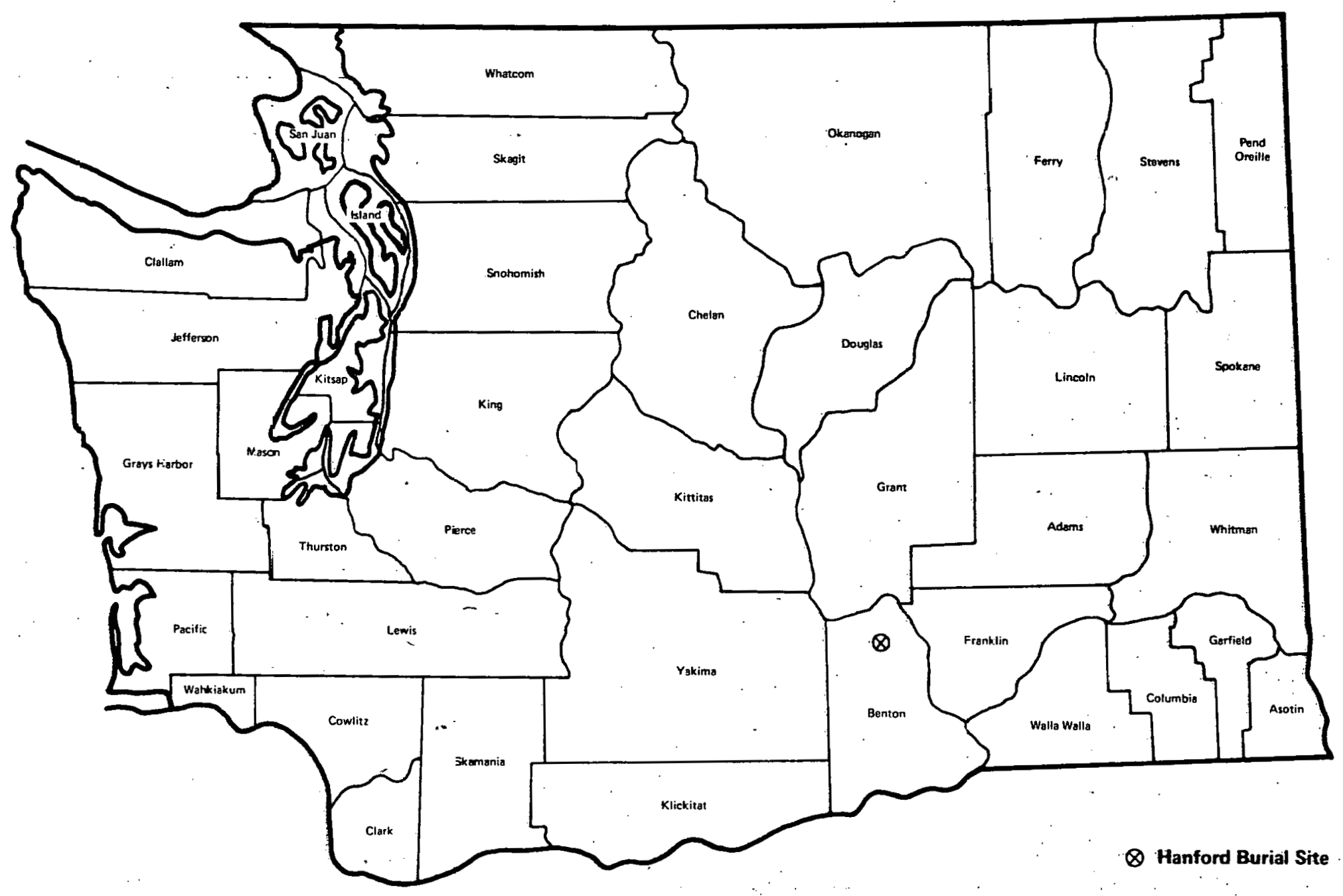


FIGURE 3-2

STANDARD METROPOLITAN STATISTICAL AREAS IN WASHINGTON (3)

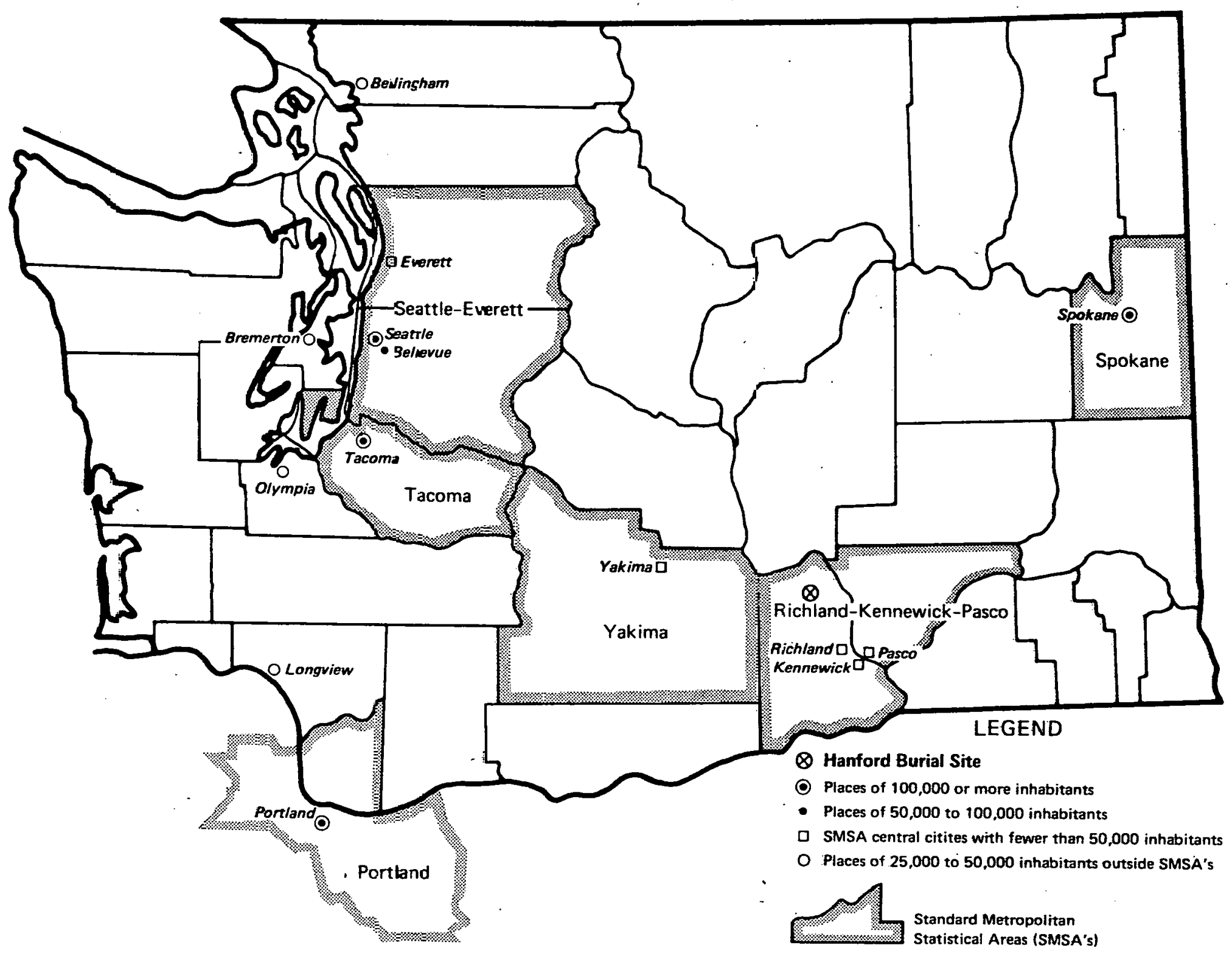


TABLE 3-1

STANDARD METROPOLITAN STATISTICAL AREAS

IN THE STATE OF WASHINGTON(3)

SMSA

Portland (Wash. portion)

Richland-Kennewick-Pasco

Seattle-Everett

Spokane

Tacoma

Yakima

State Total
POPULATION

$$
1970
$$

128,454

93,356

$1,424,605$

287,487

412,344

145,212

158,300

$3,681,000$

1977

164,800

119,100

$1,437,300$

313,100

426,200

$3,413,244$
$1,467,600$
436,900

159,300

1978

171,500

128,000

319,600

$, 774,000$ 
FIGURE 3-3

POPULATION DENEITY BY COUNTY: WASHINGTON, 1975 (2)

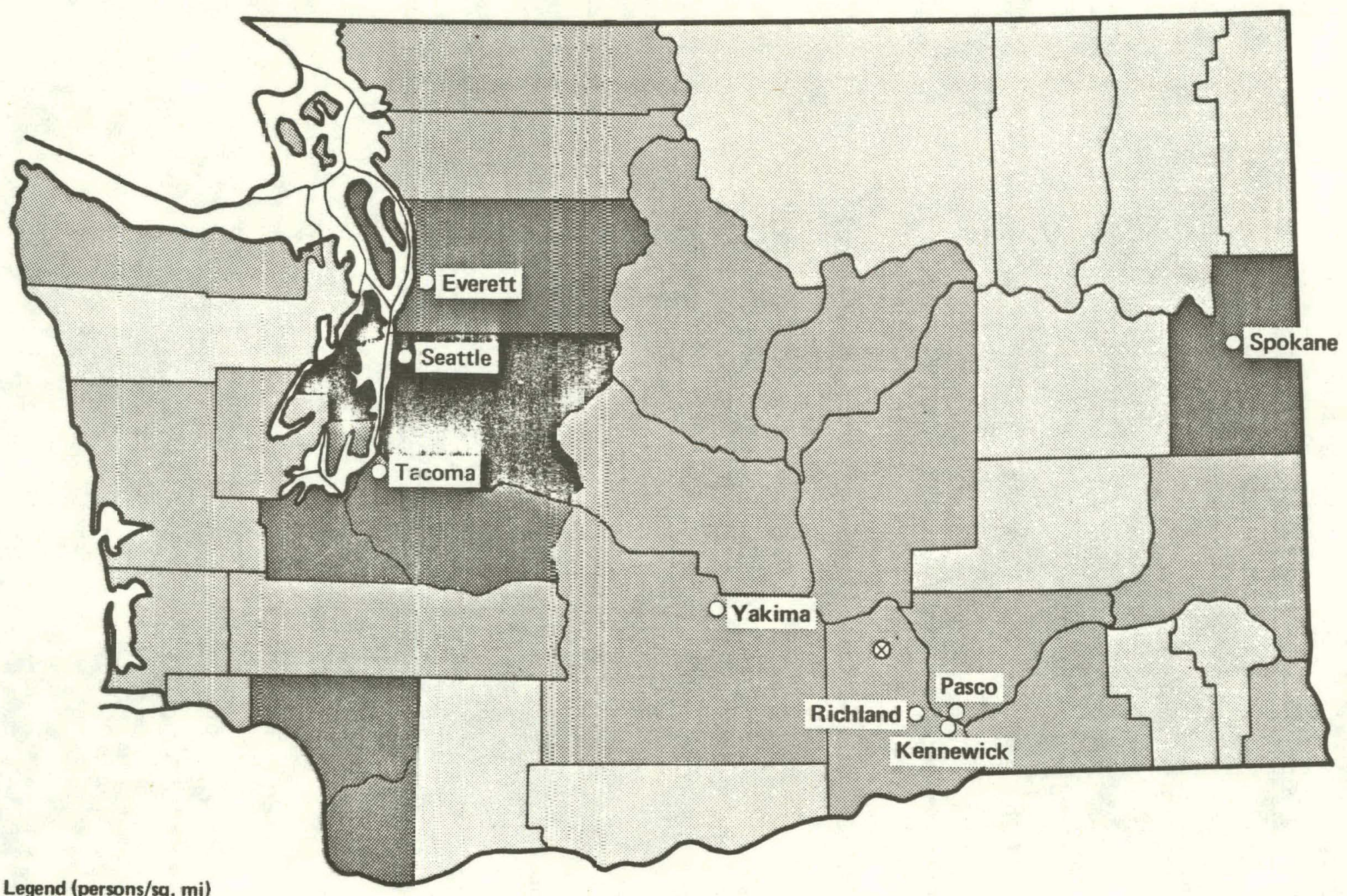

Legend (persons/sq. mi)

24:12 250 or Over $10-49$

$\otimes$ Hanford Burial Site

50-249 $\square$ Under 10


services, and government. These sectors collectively employed $1,133,400$ workers in 1978. This figure represented 24.0 percent of washington's total nonagricultural work force for that year. $(7,8)$. Table $3-2$ inventories the major economic activities of each county in the state.

\subsubsection{Employment and Per Capita Income}

There were 1,754,000 persons in Washington's labor force in 1978, of which 1,032,000 were male and 722,000 were female. This represented a total labor force participation rate of 64.0 percent, slightly above the 1978 national rate of 63.2 percent. Additionally, the state's male (78.2 percent) and female ( 50.8 percent) participation rates were slightly above the 1978 national male and female participation rates of 77.9 and 50.0 percent, respectively. (1)

During the same year, per capita income in washington was $\$ 8,450$, approximately 8.0 percent above the $1978 \mathrm{U} . \mathrm{S}$. average of $\$ 7,810$, and there were about 299,000 persons in washington living below the poverty level in 1975. This represented 8.5 percent of Washington's 1975 population as compared with 11.4 percent of the 1975 United States population. (1) Tables 3-3, 3-4, and 3-5 present an overview of washington's and the nation's labor force, per capita income, and persons living below the poverty level.

\subsubsection{Gross State Product}

Washington's gross state product (GSP) by industry has been estimated by first obtaining the gross national product (GNP) and U.S. employee compensation shown in Table 3-6. The ratio of these two measures was then computed and multiplied by the figures for employed compensation for the state. Table 3-7 presents both employee compensation and the estimated Washington GSP by industry for the years 1976, 1977, and 1978. During this period, the state's GSP rose from $\$ 28.2$ million to $\$ 27.3$ million, whereas the GNP rose form $\$ 1.6$ trillion to $\$ 2.0$ trillion. As such, Washington's GSP was 1.7 percent of the GNP in 1976 and 1.8 percent of the GNP in 1978. $(9,10,11)$ During the same 3-year period, personal income in washington rose from $\$ 18.7$ million $(1.8$ percent of U.S. income) to $\$ 24.7$ million $(1.9$ percent of U.S. income) in current dollars. (12) 
MAJOR ECONOMIC ACTIVITIES

IN WASHINGTON BY COUNTY (7)

\section{Counties}

Clallam, Jefferson, Mason, Grays Harbor, Pacific, Cowlitz, Wahkiakum, Lewis, Skamania, Ferry,

Stevens, Pen Oreille, Whatcom

Yakima, Walla Walla, Columbia, Garfield, Asotin,

Lincoln, Adams, Whitman, Douglas, Grant

Klickitat, Okanogan, Chelan

skagit

Spokane

San Juan Island

Thurston

Kitsap, Pierce, Kittitas

Snohomish, King

Benton, Franklin

Clark
Major Economic Activities

Forestry

Agriculture

Agricluture, Forestry

Forestry, Petrochemical

Trade, Service, Agriculture

Service, Trade, Agriculture, Tour isiñ

Gover mment, Forestry

Military

Aerospace

Atomin Energy racilities

Manufacturing 
TABLE 3-3

U.S. AND WASHINGTON LABOR FORCES (THOUSANDS), 1976,1978 (1)

\begin{tabular}{|c|c|c|c|c|c|c|}
\hline & \multicolumn{3}{|c|}{1976} & \multicolumn{3}{|c|}{1978} \\
\hline & Total & Male & Female & Total & Male & Female \\
\hline U.S. & 94,773 & 56,359 & 38,414 & 100,420 & 58,542 & 41,878 \\
\hline Washington & 1.587 & 934 & 653 & 1,754 & 1,032 & . 722 \\
\hline Percent of U.S. & 1.67 & 1.66 & 1.70 & 1.75 & 1.76 & 1.72 \\
\hline
\end{tabular}

TABLE $3-4$

PER CAPITA INCOME (CURRENT DOLLARS)

IN THE U.S. AND WASHINGTON FOR SELECTED YEARS (I)

\begin{tabular}{|c|c|c|c|c|}
\hline Year & U.S. & Washington & $\underline{\text { Rank }}$ & Percent of U.S. \\
\hline 1960 & 2,201 & 2,352 & 10 & 107 \\
\hline 1970 & 3,893 & 3,997 & 13 & 103 \\
\hline 1975 & 5,861 & 6,298 & 11 & 107 \\
\hline 1978 & 7,810 & 8,450 & 9 & 108 \\
\hline
\end{tabular}

TABLE 3-5

PERSONS BELOW THE POVERTY LEVEL (THOUSANDS)

IN THE U.S. AND WASHINGTON, 1969, 1975(1)

\begin{tabular}{|c|c|c|c|c|}
\hline \multirow[b]{2}{*}{ Year } & \multicolumn{2}{|c|}{ U.S. } & \multicolumn{2}{|c|}{ Washington } \\
\hline & Number & Percent & Number & Percent \\
\hline 1969 & 27,125 & 13.7 & 336 & 10.2 \\
\hline 1975 & 23,991 & 11.4 & 299 & 8.5 \\
\hline
\end{tabular}


TABLE 3-6

GROSS MATIONAL PRODUCT, C.S. EMPLOYEE COMPENSATION AND RATIO OF PRODUCT TO COMPENSATION (BILLIONS OF DOLLARS) BY INDUSTRY $(9,10,11$ )

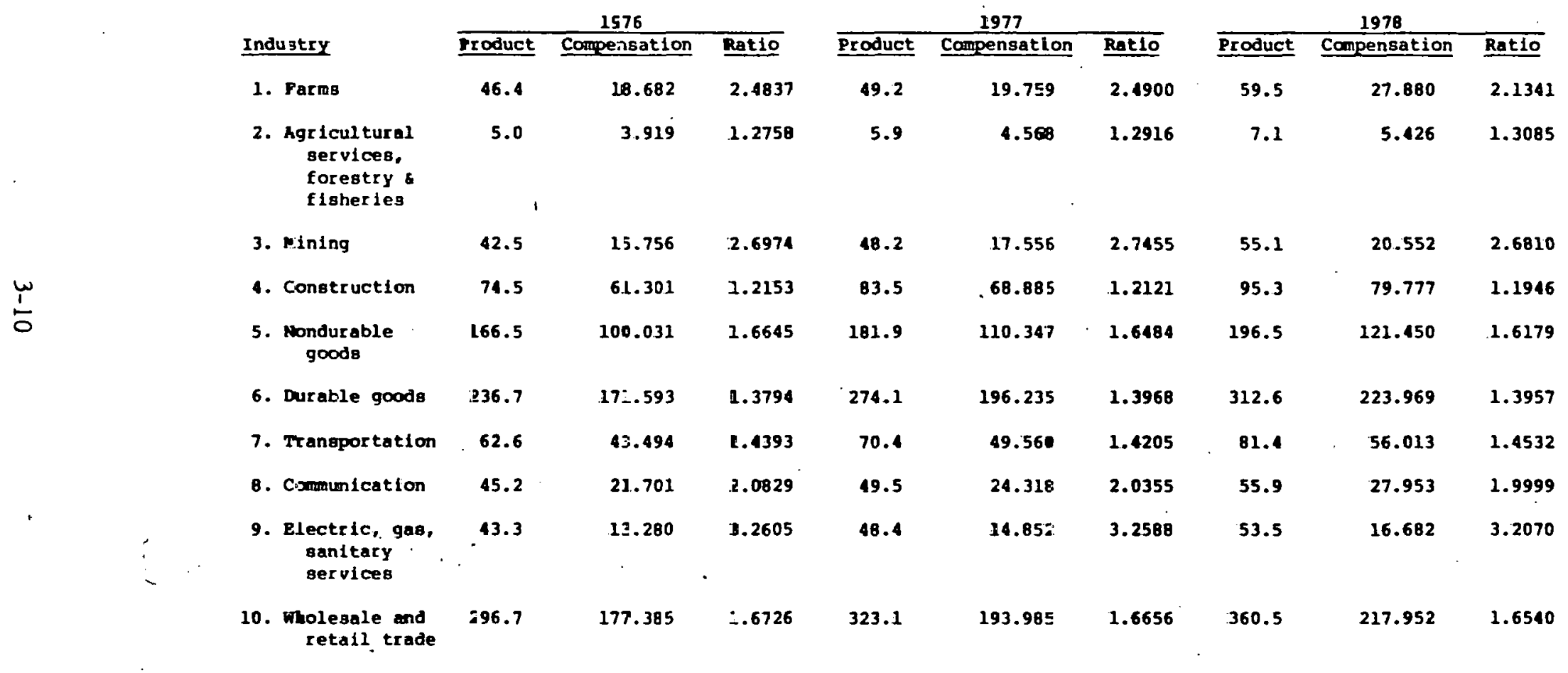


TABLE 3-6 (concluded)

GRCSS NATIONAL PRODDCT, U.S. EMPLOYEE COMPENSATION AND RATIO OF PRODUCT TO COMPENSATION (BILLIONS OF DOLLARS) BY INDUSTRY $(9,10,11$ )

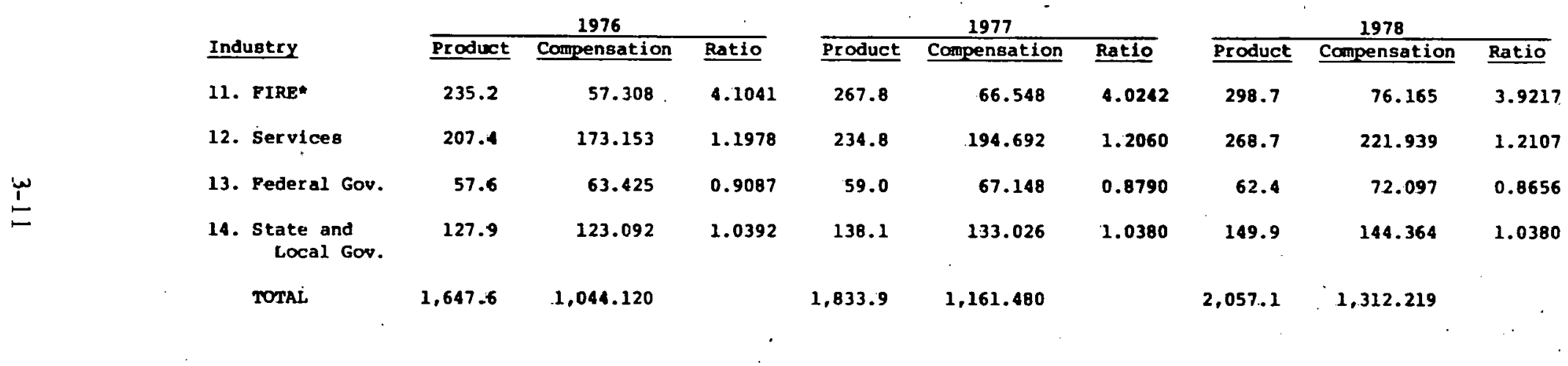

Finance, Insurance, Real Estate 
TABLE 3-7

EMPLOYEE COMPENSATION AND ESTIMATED GROSS STATE PRCDUCT (MILLIONS OF DOLLARS) BY INLUSTRY FOR WASHINGTON $(10,11)$

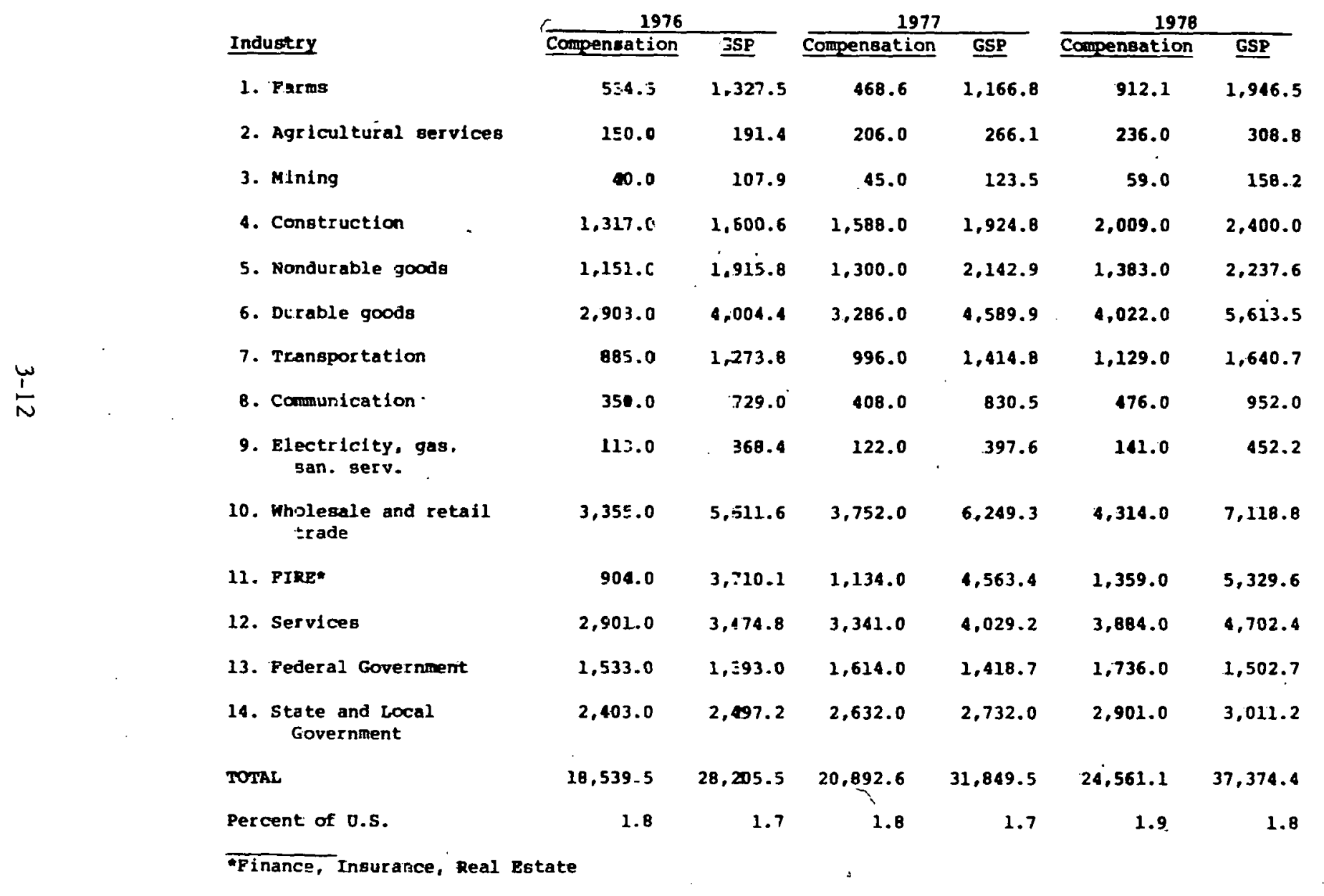


Figure 3-4 portrays percent of gross product by industry for the United States and Washington in 1978. During this time, the state differed from the nation in several areas. Farming and construction for example, were one and a half tịmes as important in Washington as they were in the nation, and agriculture was two times as important in Washington. In contrast, nondurable goods represented 9.55 percent of the U.S. output and 5.99 percent of Washington's output; electricity, gas and sanitation represented 2.60 percent of the nation's output and 1.21 percent of the state's; and mining represented 2.68 of the U.S. output compared to 0.42 percent of the output in Washington. $(9,10,11)$

\subsection{AGRICULTURE}

Washington's agricultural sector produced 12,252,000 tons of grain, forage, and miscellaneous field crops; $1,458,130$ tons of fruit and nut crops; 654,850 tons of vegetables; 28,575 tons of seed crops; and 27,469 tons of berries in 1977. The following year, every sector experienced an increase in production except the berry crop, which decreased 6.2 percent. The 1978 production figures are as follows: $14,719,000$ tons of grain, forage, and miscellaneous field crops; $1,626,630$ tons of fruit and nuts; 740,400 tons of vegetables; 40,137 tons of seed crops; and 25,777 tons of berries. The value of all crops produced in Washington was $\$ 1,247,294,000$ in 1977 and $\$ 1,549,935,000$ in 1978 . (13)

Washington's cattle and calves production in 1978 totaled 370,140,000 pounds, down 7.9 percent from the 1977 total of $399,525,000$ pounds. Hog production also decreased from $23,183,000$ pounds in 1977 to $20,597,000$ pounds in 1978. In contrast, sheep and lamb production increased 51.1 percent during this period from $2,223,000$ pounds to $3,358,000$ pounds and chicken production increased from 86,163 pounds to 89,806 sounds. The value of all livestock produced in the state increased from $\$ 486,663,000$ in 1977 to $\$ 572,459,000$ the following year.

Washington is the eleventh largest producer of milk in the nation. Milk production in the state totaled 2,546,000,000 pounds in 1977 and 2,682,000,000 pounds in 1978 . The tutal value of milk produation in the state was $\$ 255.618 .000$ in 1977 and $\$ 292,338,000$ the following year, representing a 14.4 percent annual increase. (13) Table 3-8 inventories Washington's principal agricultural comodities and presents the state's rank in the nation's agriculture. 
FIGURE 3-4

PERCENT OF GROSS PRODUCT BY INDUSTRY:

UNITED STATES AND WASHINGTON, $1978(9,10,11)$

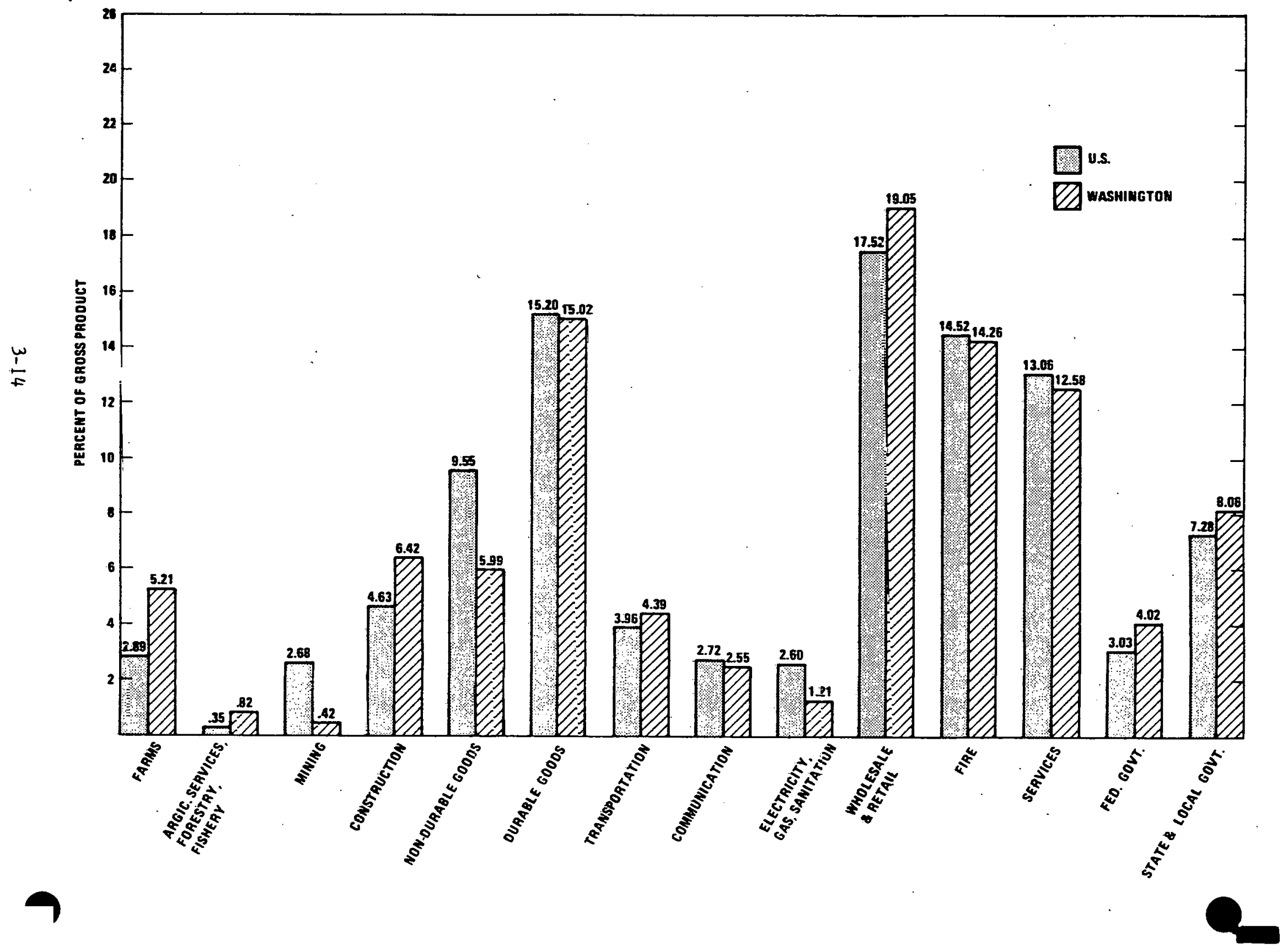


TABLE 3-8

WASHINGTON'S RANK IN THE NATION'S AGRICULTURE, $1978(1,13)$

Commodity
Crops:
Apples
Dry Edible Beans
Green Peas (for processing)
Hops
Sweet Cherries
Asparagus
Carrots (for processing)
Irish Potatoes
Pears
Grapes
Winter Wheat
Cranberies
Sweet Corn (for processing)
Dairy Products:
Milk

$\begin{array}{cc}\begin{array}{c}\text { Rank } \\ \text { Among States }\end{array} & \begin{array}{c}\text { Production as a Percent } \\ \text { of U.S. Totals }\end{array} \\ & \\ 1 & 28.4 \\ 1 & 58.3 \\ 1 & 25.7 \\ 1 & 72.7 \\ 1 & 39.2 \\ 2 & 36.8 \\ 2 & 19.4 \\ 2 & 13.9 \\ 2 & 33.8 \\ 3 & 4.1 \\ 3 & 9.8 \\ 4 & 5.7 \\ 4 & 12.7 \\ & \\ 11 & 2.14\end{array}$




\subsection{SCHOOLS, HOSPITALS, AND NATIONAL LABORATORIES}

Several institutions in Washington are potential sources of radioactive wastes through the use of radionuclides. Colleges and universities are such potential sources; Washington has 51 universities and colleges with a total enrollment of 275,299 students in the fall of 1978. This represents a 4.7 percent increase over the 1977 fall enrollment of 262,961 students. $(14,15)$ In 1977, 11 institutions had enrollments of fewer than 2,500 students; 20 had student populations numbering between 2,500 and 4,999; an additional 17 had between 5,000 and 9,999 students; and 3 had enrollments of 10,000 or more students. (14)

In addition to schools, washington had 128 hospitals with a total of 16,138 beds in 1978. Approximately 112 of these institutions had fewer than 250 beds, 13 had between 250 and 499 heds, and another 3 had more than 499 beds. (16) In 1974, Washington had 131 hospitals with a total of 16,588 beds. (17) In 1976, there were 130 hospitals in Washington with a total of 16,290 beds. The decrease in the number of hospitals, a national trend since 1967, is explained by the American Hospital Association as due to the loss of specialty hospitals, predominantly the closing of tuberculosis hospitals and the loss of beds in psychiatric hospitals. (18)

There are no national laboratories in the State of Washington. The Department of Energy, however, has two laboratories in Richland, Washington: the Pacific Northwest Laboratory and the Hanford Engineering Development Laboratory. The Pacifico Northwest Laboratory employed approximately 2,600 persons in 1979 and projections concerning future employment in the laboratory are currently unavailable. (19) During the same year, approximately 3,000 persons were employed in the Hanford Engineering Development. Laboratory and the laburatory's labor force is expected to. experience limited growth over the next 5 years. (20) 


\section{REFERENCES}

1. U.S. Department of Commerce, Bureau of the Census, Statistical Abstract of the United States, 1979, 100th edition. U.S. Government Printing office, Washington, D.C., 1979.

2. U.S. Department of Commerce, Bureau of the Census, County and City Data Book, 1977. U.S. Government Printing Office, Washington, D.C., 1977.

3. U.S. Department of Commerce, Bureau of the Census, current Population Reports: Population Estimates and Projections, Series P-26, Estimate of the Population of Washington Counties and Metroplitan Areas. U.S. Government Printing office, Washington, D.C., July 1979.

4. Personal communication with Joan Keemer, National Center for Health Statistics, Division of Vital Statisțics; August 6, 1980 .

5. Personal communication with Thelma Tassel, National Center for Health Statistics, Division of Vital Statistics, August 6, 1980.

6. Personal communication with Beulah Land, Census Bureau, October $15,1979$.

7. U.S. Department of Commerce, Bureau of the Census, County Business Patterns, 1977. U.S. Government Printing office, Washington, D.C., 1979.

8. Employment Security Department, State of Washington, "Labor Force and Employment in Washington State," Memorandum. April 1979.

9. U.S. Department of Commerce, Bureau of Economic Analysis, Survey of Current Business, Volume 59, Number 7. U.S. Government Printing Office, Washington, D.C., July 1979 .

10. U.S. Department of Commerce, Bureau of Economic Analysis, Survey of Current Business, Volume 59, Number 8, Part II. U.S. Government Printing office, Washington, D.C., August 1979. 
11. Personal communication with Andy Weiser, Bureau of Economic Analysis, Economic Measurements Division, June 1, 1980.

12. Personal communication with Stewart Schwartz, Bureau of Economic Analysis, Economic Measurements Division, August 5, 1980.

13. Washington Crop and Livestock Reporting Service, Washington Agricultural Statistics, 1978. U.S. Department of Agriculture, Washington Department of Agriculture, Seattle, Washington, 1978.

14. Arthur Poddsky and Carolyn R. Smith, Education Directory, Colleges and Universities, 1977-1978. U.S. Department of Health, Education and Welfare, National Center for Education Statistics, Washington, D.C., 1978.

15. Personal communication with Vance Grant, U.S. Department of Health, Education and Welfare, Department of Education, Statistics Division, November 19, 1979.

16. American Hospital Association, Guide to the Health Care Field. American Hospital Association, Chicago, Illinois, 1978.

17. National Center for Health Statistics, Public Health Service, Hospitals: A County and Metroplitan Area Data Book, 1974. U.S. Department of Health, Education and Welfare, Washington, D.C., 1978.

18. National Center for Health Statistics, Office of Health Research Statistics and Technology, Public Health Service, Health Resource Statistics, 1976-1977 edition. U.S. Department of Health, Education and Welfare, Washington, D.C, , 1977.

19. Personal communication with Cherie Smith, Hanford Engineering Development Laboratory, August 18, 1980.

20. Personal communication with Wayne Meisinger, Department of Personnel, Pacific Northwest Laboratory, August 18, 1980. 
4. GOVERNMENT

This section presents an overview of Washington's state government and identifies the government institutions and agencies with statutory or other responsibilities affecting the generation, handling, and disposal of radioactive wastes within the state. The identities and attitudes, of state officials and other organizations impinging on this issue are presented in the text, and where possible in available representative print media.

\subsection{MA.JOR POLITICAL PARTIES}

A11 Washington legislators are currently affiliated with either the Democratic or the Republican Party. In the Washington Senate, the Republicans hold 25 seats and the Democrates hold 24. Of the 98 seats in the Washington House of Representatives, the Republicans hold 56 seats and the Democrates 42. Both of Washington's United States Senators and five of its seven United States ' Congressional Representatives are Democrats. (1)

\subsection{CONGRESSIONAL REPRESENTATIVES}

Washington's two United States Senators are Slade Gorton (Republican) and Henry M. Jackson (Democrat). (1) Senator Jackson is interested in the continued opcration of existing molpar facilities and the construction of those previously planned. In addition, he is interested in an energy program that provides for a mixture of fossil and nuclear fueled electric generating facilities. As a member of three subcommittees of the Committee on Armed Services, Senator Jackson is involved in the national security aspects of nuclear energy. He is also Chairman of the Committee on Energy and Natural Resources which is responsible for all proposed legislation, messages, memorials, and petitions relating to energy policy, energy regulations, energy research and development, and the nonmilitary development of nuclear energy. As a member of the Committee on Governmental Affairs, Subcommittee on Energy, Nuclear Proliferation and Federal Services, Senator Jackson is involved in the committee's responsibility for organizing and managing the nation's nuclear export policy. $(2,3)$ 
As a member of two subcommitteés on the Committee of Commerce, Science, and Transportation, Senator Gorton may become involved in. issues concerning the transportation of nuclear wastes because the committee is responsible for regulating interstate carriers and highway safety throughout the nation. (3)

Washington is also represented in the United States Congress by \$even Representatives, who are presented in Table 4-1 in conjunction with Washington's Senators. (1) The table also indicates the congressional committees the Senators and Representatives serve on and their length of service. Additionally, Figure 4-1 indicates the location of Washington's congressional districts.

\subsection{STATE GOVERNMENT}

The Washington government is divided into three branches as regulated by the Washington Constitution (adopted in 1889) and numerous federal and state statutes. The specified branches are the Executive, Legislative, and Judicial. (5)

\subsubsection{Executive Branch}

The executive brauch, under the Governor, carries on the business of the government and executes the laws enacted by the state legislature. The elected officials of the executive branch include the Governnr, the Lieutenant Governor, the serretary of Etate, the Theasurer, the Auditor, the Attorney General, the Superintendent of Public Instruction, and the Commissioner of Public Lands. (5)

\section{Governor}

The present Governor, John Spellman (Republican), was elected in 1980, (1) The Governor exercises administrative powcr over the guvernment by the appointment of numerous members of state departments, agencies, and institutions. Additionally, certain positions outside the executive branch, such as supreme court judges, are initially filled by guhernatorial 
TABLE $4-1$

WASHINGTON MEMBERS OF THE UNITED STATES CONGRESS $(3,4)$

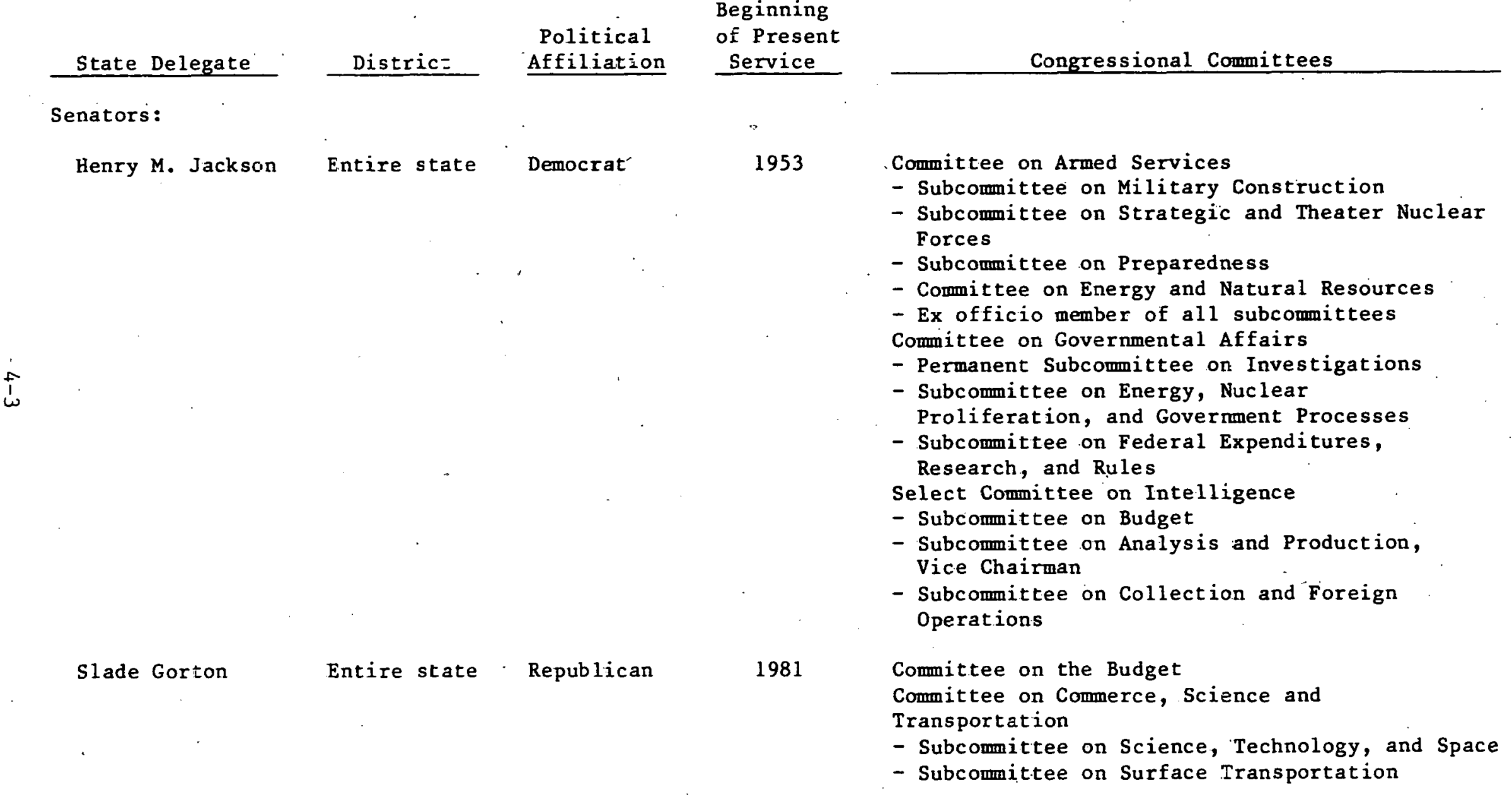


WASHIRGTON MEMBERS OF THE UNITED STATES CONGRESS $(3,4)$

\begin{tabular}{|c|c|c|c|c|}
\hline State Delegate & District & $\begin{array}{c}\text { Po-itical } \\
\text { Azf-liation }\end{array}$ & $\begin{array}{l}\text { of Present } \\
\text { Service } \\
\end{array}$ & Congressional Comittees \\
\hline Representatives: & , & & & \\
\hline Joel, Pritchard & First & Republican & 1973 & $\begin{array}{l}\text { Committee on Foreign Affairs } \\
\text { - Subcommittee on Asian and Pacific Affairs } \\
\text { - Subcommittee on Human Rights and International } \\
\text { Organization } \\
\text { - Subcomittee on International Operations } \\
\text { Committee on Merchant Marines and Fisheries } \\
\text { - Subcommittee on Fisheries, Wildlife } \\
\text { Conservation and the Environment } \\
\text { - Subcomittee on Oceanography }\end{array}$ \\
\hline Al Swift & Second & Denocrat & 1979 & $\begin{array}{l}\text { Committee on House Administration } \\
\text { - Subcommittee on Accounts } \\
\text { - Subcommittee on Office Systems } \\
\text { Committee on Energy and Commerce } \\
\text { - Subcommittee on Energy Conservation and Power } \\
\text { - Subcommittee on Fossil and Synthetic Fuels } \\
\text { - Subcommittee on Telecommunications, Consumer } \\
\text { Protection and Finance } \\
\text { Joint Committee on the Libraries }\end{array}$ \\
\hline Don Bonker & Third & Democ $=a t$ & $\begin{array}{l}197.5 \\
-\end{array}$ & $\begin{array}{l}\text { Committee on Foreign Affairs } \\
\text { - Subcommittee on Human Rights and International } \\
\text { Organizations, Chairman } \\
\text { - Subcommittee on International Economic Policy } \\
\text { and Trade }\end{array}$ \\
\hline
\end{tabular}


TABLE 4-1 (continued)

WASHINGTON MEMBERS OF THE UNITED STATES CONGRESS $(3,4)$

\begin{tabular}{|c|c|c|c|c|}
\hline State Delegate & District & $\begin{array}{c}\text { Political } \\
\text { Affiliation } \\
\end{array}$ & $\begin{array}{l}\text { Beginning } \\
\text { of Present } \\
\text { Service } \\
\end{array}$ & Congressional Committees \\
\hline $\begin{array}{l}\text { Sid Morrison } \\
\text {. }\end{array}$ & Fourth & Repub lican & 1981 & $\begin{array}{l}\text { Committee on Agriculture } \\
\text { - Subcomittee on Cotton, Rice, and Sugar } \\
\text { - Subcomittee on Conservation, Credit, and } \\
\text { World Development } \\
\text { - Subcommittee on Forests, Family Farms, and } \\
\text { Energy }\end{array}$ \\
\hline Thomas S. Foley & Fifth & Democ $=a t$ & 1965 & $\begin{array}{l}\text { Committee on Agriculture } \\
\text { - Subcommittee on Wheat, Soybeans, and Feed } \\
\text { Grains, Chairman } \\
\text { - Subcommittee on Cotton, Rice, and Sugar } \\
\text { - Subcommittee on Department Operations, } \\
\text { Research, and Foreign Agriculture } \\
\text { - Subcommittee on Domestic Marketing, Consumer } \\
\text { Relations and Nutrition } \\
\text { - Subcomittee on Forests, Family Farms, and } \\
\text { Energy }\end{array}$ \\
\hline $\begin{array}{c}\text { Norm D. Ficks } \\
\ddots\end{array}$ & Sizth & Democ $=a t$ & 1977 & $\begin{array}{l}\text { Committee on Appropriations } \\
\text { - Subcommittee on Defense } \\
\text { - Subcommittee on Interior } \\
\text { - Subcommittee on Legislative }\end{array}$ \\
\hline Mike Lowry & Seventh & Democ:at & 1979 & $\begin{array}{l}\text { Committee on Banking, Finance and Urban } \\
\text { Affairs } \\
\text { - Subcommittee on Housing and Community } \\
\text { Development }\end{array}$ \\
\hline
\end{tabular}


TABLE 4-1 (continued)

WASHINGTON MEMBEES OF THE UNITED STATES CONGRESS $(3,4)$

State Delegate

Representative Lowry $\left(\operatorname{con}^{\prime} t\right)$

\section{Beginning of Present \\ Service}

Political

Affiliation

District
Congressional Committees

- Subcommittee on International Development, Institutions, and Finance

- Subcomittee on International Trade,

Investment and Monetary Policy

Committee on Merchant Marines and Fisheries

- Subcomitree on Coast Guard Navigation

- Subcomittee on Fisheries, Wildlife

Conservation and the Environment

- Subcommittee on Panama Canal and Outer Continental Shelf 
FIGURE 4-1

WRSHINGTON CONGRESSIONAL DISTRICTS (6)

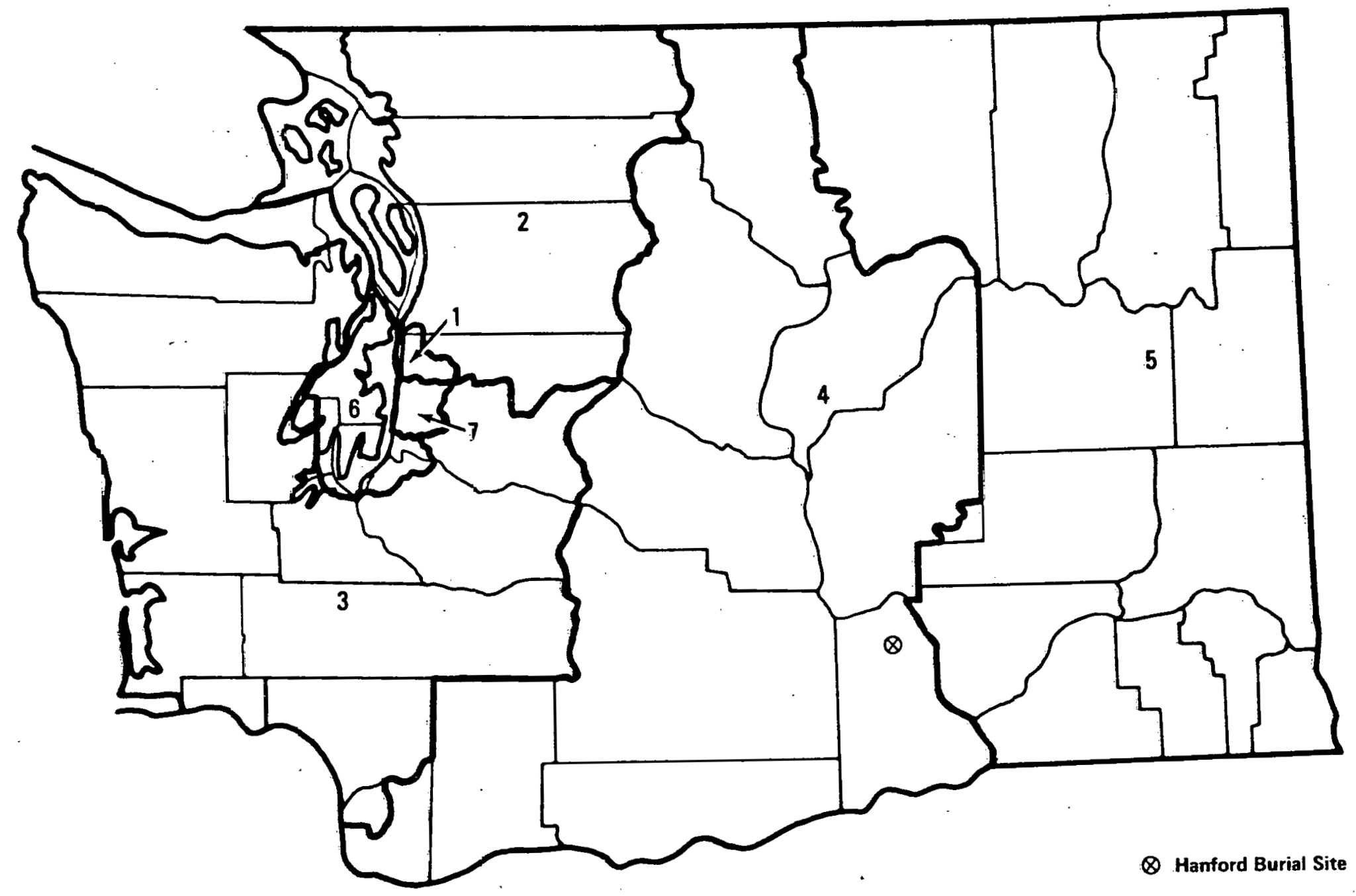


appointment. The Governor influences the legislative process by submitting recommendations and an annual budget to the legislature, by calling special legislative sessions and by exercising his power to approve or veto legislation. As Governor, John Spellman is also Commander-in-Chief of Washington's military forces and the state constitution vests the pardoning power in the Governor, subject to regulations and restrictions prescribed by law. (5)

When Governor Spellman assumed office in mid-January 1981, he identified as one of his priorities the creation of a regional compact among the northwest states to deal with the issue of low-level radioactive wastes. The Governor strongly supports states providing the primary leadership in solving this aspect of the nuclear waste problem. The Washington legislature responded by adopting the compact language, and through similar action taken in Idaho and Oregon, the compact was achieved. ( 6 )

\section{$\underline{\text { Lieutenant Governor }}$}

The present Lieutenant Governor, John A. Cherberg (Democrat), was elected in 1976 and his term also ends in 1985. (1) As Lieutenant Governor, Mr. Cherberg serves as president of the Senate "and shall discharge such other duties as may be prescribed by law." In addition, Lieutenant Governor Cherberg assumes the responsiblities of the Chief Executive in the event of the removal, resignation, death, or disability of the Governor. (5)

\section{Secretary of State}

Ralph Munro (Republican) is Washington's current Secretary of State and his term will end in 1985 . (1) The Secretary of State is responsible for keeping a record of all official acts of the executive department and the legislature, and for "performing such other duties as shall be assigned by law." (5)

\section{At torney General}

The present Attorney General, Kenneth 0. Eikenberry (Republican), was elected in 1980. As Attorney General, he is Washington's chief legal advisor and 
provides legal counsel to executive officials, members of the legislature, and to the prosecuting attorneys of the state's 39 counties. He also represents in court, the officers, departments, boards, commissions, and other institutions of the state government. $(1,7)$

\section{Other Elected Officials}

Other major elected state officials include: Robert S. O'Brien, State Treasurer; Robert V. Graham, State Auditor; Frank Brouillet, Superintendent of Public Instruction; Brian Boyle, Commissioner of Public Lands; and Richard G. Marquardt, Insurance Commissioner. (1)

\section{State Agencies}

The Washington Department of Social and Health Services, Radioactive Materials Control Unit, is responsible for radiation control in Washington, which includes regulating the transportation and disposal of nuclear materials. Since Washington is an Agreement State, the state is virtually free to regulate activities within its borders, provided the state upholds the guidelines of the Nuclear Regulatory Commission. $(6,8)$

In addition to the Department of Social and Health Services, other state agencies such as the Department of Natural Resources, the State Energy Office, the Department of Ecology, or the office of Fiscal Management may become involved in nuclear energy or radioactive waste disposal issues because of interest or jurisdiction in the areas of land-use planning and environmental management or protection. Figure 4-2 inventories Washington's state agencies.

\subsubsection{Legislative Branch}

The legislative power of the state is vested in the State Senate and the house of Representatives. The Washington Constitution provides for the state to be divided into 49 legislative districts. One senator is elected from each of the 49 districts, 2 representatives from each of, 48 districts, and 3 representatives from 1 district. (D) 
F IGURE 4-2

LIST OF STATE AGENCIES (9)

WASHINGTON

ADJUTANT GENERAL

George E. Coates, The Adjutant General Washington National Guard

Camp Murray

Tacoma, WA 98430

(206) $964-6201$

\section{ADMINISTRATION}

Keith A. Angier, Director

Department of General Administration

218 General Administration B1dg.

Mail Stop $\mathrm{AX}-22$

Olympia, WA 98504

(206) 753-5434

\section{AERONAUTICS}

W. H. Hamilton, Assistant Secretary for Aeronautics

Division of Aeronautics

Department of Transportation

Boeing Field

8600 Perimeter Rd.

Seattle, WA 98108

(206) $764-4131$

\section{AGING}

Charles E. Reed, Director

Bureau of Aging and Adult Services

Department of Social and Health Services

Mail Stop OB-43G

01 ympia, WA 98504

(206) 753-2502

\section{AGR ICULTURAL}

M. Keith Ellis, Director

Department of Agriculture

406 General Administration Bldg.

O1ympia, WA 98504

(206) 753-5050

AIR POLLUTION CONTROL

Peter W. Hildebrandt, Assistant Director

Office of Air Programs

Department of Ecology

Mail Stop PV-11

Olympia, WA 98504

(206) 753-2821
ALCOHOLISM

Everett L. Atkins, Jr., Chief

Office of Alcoholism

Bureau of Social Services

Department of Social and Health Services

Office Bldg. 2

Mail Stop OB-44W

Olympia, WA 98504

(706) 753-5866

ARCHIVES AND RECORDS

Sidney McAlpin, State Archivist Archives and Records Management Department of General Administration

12 th and Washington Sts.

Olympia, WA 98501

(206) 753-5468

ARTS AND HUMANITIES

Michael A. Croman, Executive Director

Arts Commission

Mail Stop $\mathrm{GH}-11$

Olympia, WA 98504

(206) 753-3860

William H. 01iver, Executive Dịrector

Washington Commission for the Humanities

c/o Evergreen State College

Olympia, WA 98505

(206) 866-6510

ATTORNEY GENERAL

Kenneth 0. Eikenberry, Attorney General

Temple of Justice

01 ympia, WA 98504

(206) 753-2550

AUDIT

Robert V. Graham, State Auditor Office of State Auditor

Legislative Bldg.

Olympia, Wh $9850 /$

(206) 753-5280 


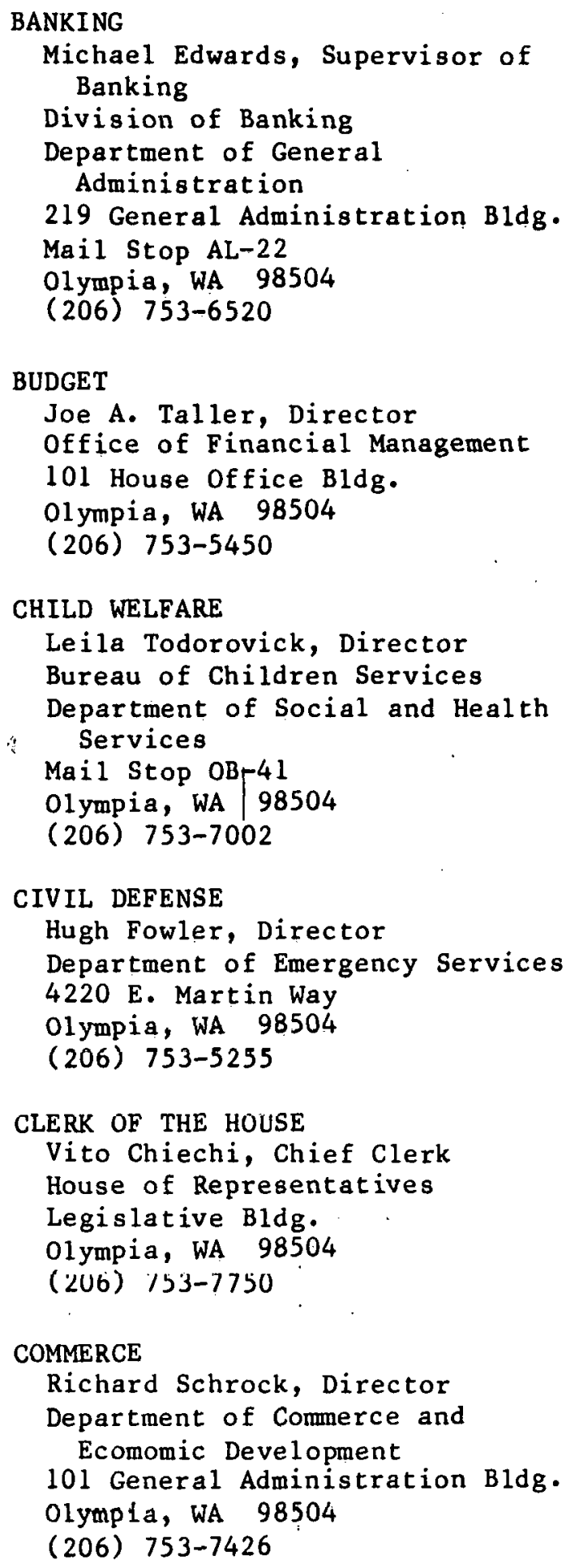

\section{BUDGET}

Joe A. Taller, Director

Office of Financial Management

101 House Office B1dg.

Olympia, WA 98504

(206) 753-5450

\section{COMMUNITY AFFAIRS}

Karen Rahm, Director

Planning and Community Af fairs Agency

400 Capitol Center Bldg.

410 W. 5th St.

Olympia, WA 98594

(206) 753-2219

\section{CONFLICT OF INTEREST}

Graham E. Johns, Administrator Public Disclosure Commission 403 Evergreen Plaza Building 7 th and Capitol Way

Olympia, WA , 98504

(206) 753-1980

\section{CONSUMER AFFAIRS}

Doug Shadel, Chief

Consumer Protection Division

office of Attorney General

122 No. Capitol Way

Olympia, WA 98504

(206) 753-2550

\section{CORRECT IONS}

Amos E. Reed, Director

Department of Corrections

Mail Stop FN-61

Olympia, WA 98504

(206) 753-2500

\section{COURT ADMINISTRATION}

Harold S. Primer, Administrator

Administrator for the Courts

Temple of Justice

Olympia, WA 98504

(206) 753-5780

DATA PROCESSING

Terrence Wold, Executive Director Data Processing Authority

9 th and Columbia B1dg., Suite 360 Mail stop GH-31

Olympia, WA 98504 
DRUG ABUSE

William T. Quick, Chief

Office of Drug Abuse Prevention

Bureau of Alcohol and Substance Abuse

Department of Soicial and Health Services

Office Bldg. 2

Mail stop OB-44W

Olympia, WA 98504

(206) 753-3073

ECONOMIC DEVELOPMENT

Richard Schrock, Director

Department of Commerce and Economic Development

101 General Administration Bldg. Olympia, WA 98504

(206) 753-7426

ECONOMIC OPPORTUNITY

Art Cantrall, Acting Assistant Director

Division for Community Services

Planning and Community Affairs Agency

9 th and Columbia Bldg.

Mail Stop GH-5l

Olympia, WA 98504

(206) 753-4983

EDUCATION (higher)

Gail Norris, Executive Coordinator

Council for Postsecondary Education 908 E. 5th Ave.

Olympia, WA 98504

(206) 753-3241

EDUCATION (primary, secondary, and vocational)

Frank B. Brouillet, State Superintendent of Public Instruction

7510 Armstrong St. S.W.

Tumwater, WA 98504

(206) 753-6717

ELECTIONS

Donald Whiting, Elections

Supervisor

Office of the Secretary of State

Legis lative Bldg.

Olympia, WA 98504

(206) 753-2336
EMPLOYMENT SECURITY

Norward. J. Brooks, Commissioner

Employment Security Department

212 Maple Park

O1ympia, WA 98504

(206) 753-5114

\section{ENERGY}

Edward Sheets, Director

State Energy office

400 E. Union St.

Olympia, WA 98504

(206) 754-1350

ENV IRONMENTAL AFFAIRS

Donald W. Moos, Director

Department of Ecology

Mail Stop PV-11

Olympia, WA 98504

(206) 753-2240

F INANCE

Peter T. Kerr, State Finance office

State Finance Committee

Office of State Treasurer Legislative Bldg.

Mail Stop AS-23

Olympia, WA 98504

(206) 753-1464

FISH AND GAME

Rolland A. Schmitten, Director Departmcnt of Fisheries

115 General Adminiotration Bldg. Olympia, WA 98504

(206) 753-6623

Frank R. Lockard, Director

Department of Game

600 N. Capitol Way

O1.ympia, WA 98504

(206) 753-5710

FOOD AND DRUG

James E. Wummack, Ass istanc Director

Dairy and Food Division

Department of Agriculture

406 General Administration Bldg. 01 ympia, WA 98504

(206) 753-5042 


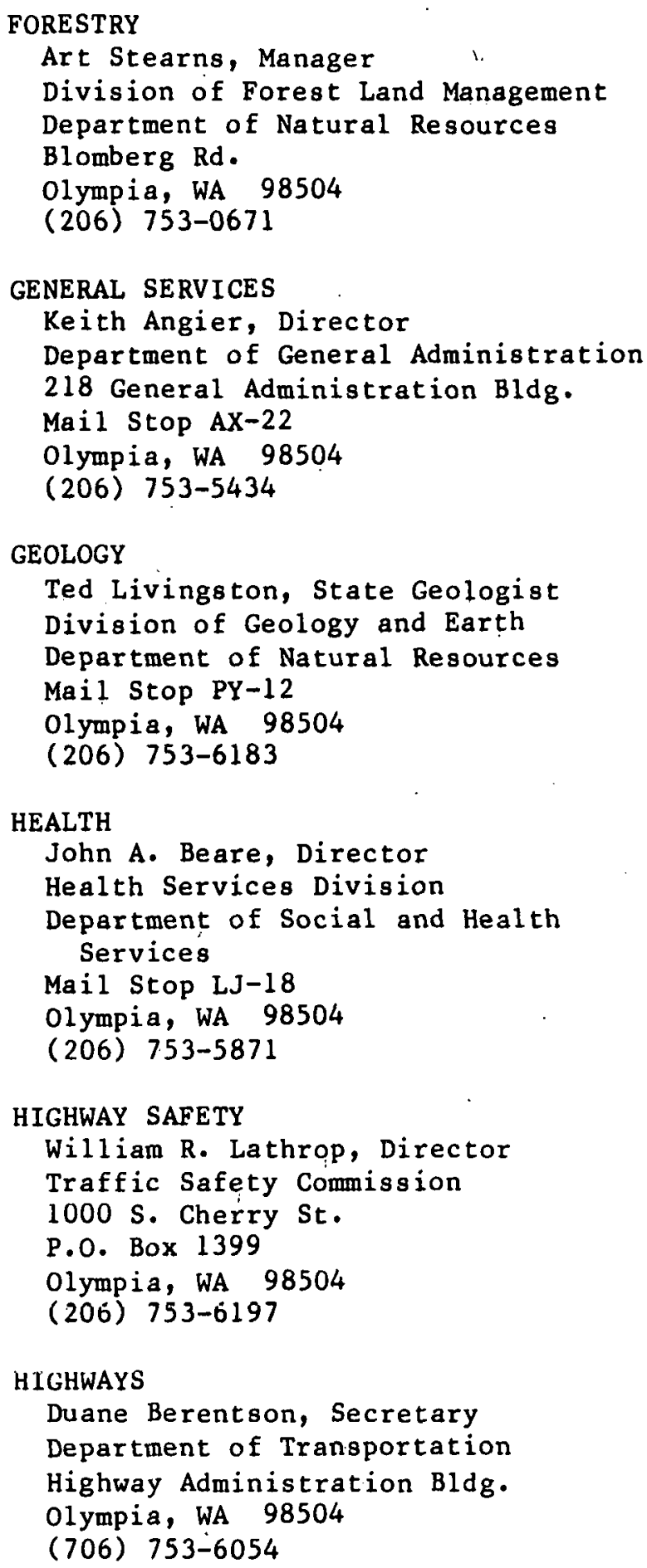

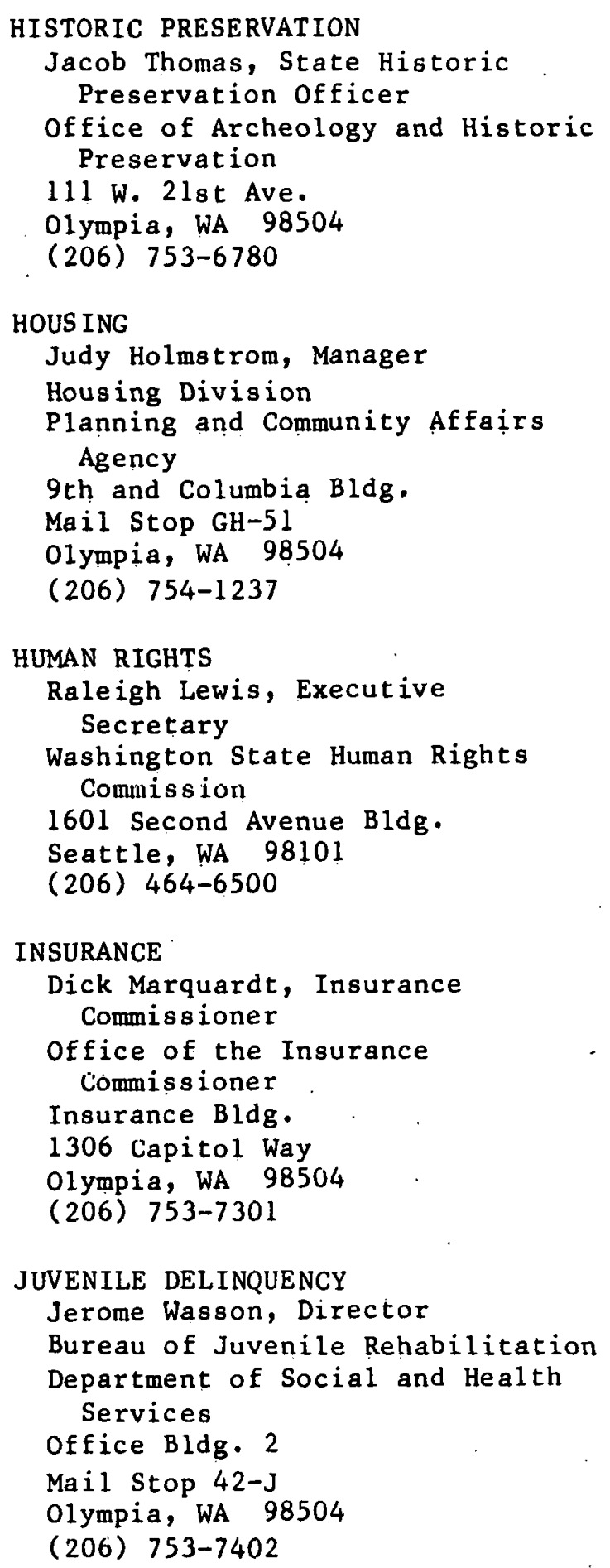


LABOR

Sam Kinville, Director

Department of Labor and Industries 334 General Administration B1dg. Olympia, WA 98504

(206) 753-6307

\section{LEGISLATIVE RESEARCH}

J. Arnold Bricker, Staff Director Senate Research Center

101 Senate office Bldg. Olympia, WA 98504

(206) 753-6826

LIBRARY SERVICES

Roderick G. Swartz, State Librarian

State Library

State Library B1dg.

01 ympia, WA 98504

(206) 753-2915

LICENSING (occupational and professional)

John Gonsalez, Director

Business and Professions Administration

Department of Licensing

Highways-Licenses B1dg.

P.O. Box 9649

Olympia, WA 98504

(206) 753-1369

LIQUOR CONTROL

Leroy M. Hittle, Chairman

Liquor Control Board

Capitol Plaza Bldg.

$1025 \mathrm{E}$. Union St.

Olympia, WA 98504

(206) 753-6263

MASS TRANSIT

Robert Nielson, Assistant Secretary for Public Transportation and Planning

Highway Administration B1dg. Olympla, WA 98504

(206) 753-6101

\section{MENTAL HEALTH}

Muriel K. Taylor, Director

Bureau of Mental Health

Department of Social and Health Services

Office B1dg. 2

Mail Stop OB-42F

Olympia, WA 98504

(206) 753-5414

MENTAL RETARDATION

Maurice A. Harmon, Director

Bureau of Developmental Disabilities

Department of Social and Health Services

Office Bldg. 2

Mail Stop $O B-42 C$

Olympia, WA 98504

(206) 753-3900

MINING

Vaughn E. Livingston, Jr., Supervisor

Division of Geology and Earth Resources

Department of Natural Resources $1404 \mathrm{~S}$. Jefferson St.

Olympia, WA 98504

(206) 753-6183

MOTOR VEHICLES

John Gonsalez, Director

Department of Licensing

Highways-Licenses Bldg.

Olympia, WA 98504

(206) 753-6915

NATURAT, RF.SOIIRCES

Brian J. Boyle, Commissioner

Department of Natural Resources

Public Lands Bldg.

Olympia, WA 98504

(206) 753-5317

NUCLEAR ENERGY

Edward Sheets, Director

State Energy office

400 E. Union St.

Olympia, WA 98504

(206) $754=1350$ 
OCCUPATIONAL SAFETY AND HEALTH

James P. Sullivan, Assistant Director Industrial Safety and Health Division Department of Labor and Industries 308 E. 4th Ave.

P.0. Box 207

Olympia, WA 98504

(206) 753-6500

OIL AND GAS

Edward Sheets, Director

State Energy office

400 E. Union St.

Olympia, WA 98504

(206) 754-1350

\section{PARKS}

Jan Tveten, Director

Parks and Recreation Commission

7150 Cleanwater La.

P.0. Box 1128

Olympia, WA 98504

(206) 753-5757

PERSONNEL

Leonard Nord, Director

Department of Personnel

600 S. Frankl in St.

P.0. Box 1789

Olympia, WA 98504

(206) 753-5358

\section{PLANN ING}

Thomas A. Mahar, Assistant Director Policy Analysis Division

Office of Financial Management

109 House office Bldg.

Olympia, WA 98504

(206) 753-5297

\section{POLICE}

Neil Moloney, Chief

Washington State Patrol

General Administration Bldg.

01 ympia, WA 98504

(206) 753-6540

PRINTING AND PUBLISHING

William D. Hanson, Public Printer Department of Printing

General Administration Bldg.

P.0. Box 798

O1ympia, WA 98504

(206) 753-6820
PROBATION AND PAROLE

William E. Henry, Chairman

Board of Prison Terms and Paroles

700 Capitol Center B1dg.

410 W. 5th St.

Mail Stop FN-71

Olympia, WA 98504

(206) 753-6797

PUBLIC UTILITIES

Robert W. Bration, Executive of $f$ icer

Utilities and Transportation Commission

Highways-Licenses Bldg.

Olympia, WA 98504

(206) 753-6423

PUBLIC WORKS

John E. Mikkelsen, Assistant

Director,

State Facilities

- Department of General Administration

218 General Administration Bldg. Olympia, WA 98504

(206) 753-3151

PURCHASING

R. A. Schwendiman, Director

Division of State Purchasing

Department of General Administration

216 General Administration Bldg: Olympia, WA 98504

(206) 753-6461

\section{RAILROADS}

Leon R. Kegley, Assistant Administrator of Transportation

Transportation Division

Utilities and Transportation Commission

Highways-Licenses Bldg.

Olympia, WA 98504

(206) 753-6065

\section{RETIREMENT}

R. L. Hollister, Jr., Director Department of Retirement Systems Capitol Plaza Bldg.

1025 E. Union St.

Olympia, WA 98504

(206) 753-5281 
SECRETARY OF STATE

Ralph Munro, Secretary of State Office of the Secretary of State Legiglative Bldg.

Olympia, WA 98504

(206) 753-7121

\section{SECRETARY OF THE SENATE \\ Sid Snyder, Secretary \\ Senate \\ Legislative Bldg. \\ Olympia, WA 98504 \\ (206) 753-7550}

\section{SECURITIES}

Eugene G. Olson, Administrator

Securities Division

Department of Motor Vehicles

Highways-Licenses Bldg.

Olympia, WA 98504

(206) 753-6928

\section{SOCIAL SERVICES}

Alan Gibbs, Secretary

Department of Social and Health Services

Office Bldg. 2

Mail Stop OB-44

Olympia, WA 98504

(206) 753-3395

SOLID WASTE MANAGEMENT

Phil Clark, Supervisor

Solid Waste Management Division

Office of Land Programs

Department of Ecology

Mail Stop PV-11

Olympia, WA 98504

(206) 753-6883

STATE-LOCAL RELATIONS

Jeff Harris, Administrator

Local Government Services

Division

Planning and Community Affairs Agenry

400 Capitol Center Bldg.

410 W. 5th St.

Olympia, WA 98504

(206) 753-4900
TAXATION AND REVENUE

Glenn Pascall, Director

Department of Revenue

General Administration Bldg.

Olympia, WA 98504

(206) 753-5512

TOURISM

Al Hunter, Director

Travel Development Division

Department of Commerce and Economic Development

101. General Administration Bldg. Olympia, WA 98504

(206) 753-5610

\section{TRANSPORTATION}

A. G. Duclos, Administrator

Transportation Division

Utilities and Transportation Commission

Highways-Licenses Bldg.

Olympia, WA 98504

(206) 753-6512

Duane Berentson, Secretary Department of Transportation Highway Administration Bldg. Olympia, WA 98504

(206) 753-6054

TREASURER

Robert S, O'Brien, State Treasurer

Legislative Blig.

Olympia, WA 98504

(206) 753-7130

VETERANS' AFFAIRS

Hector lórres, Director

Department of Veterans' Affairs

E. 11 th and S. Washington Sts.

P.0. Box 9778

Olympia, WA 98504

(206) 753-5586 
VITAL RECORDS/STATISTICS

Fred Goodrich, State Registrar

Vital Statistics Unit

Health Services Division

Department of Social and Health Services

Airdustrial Park

P.O. Box 9709

Olympia, WA 98504

(206) 753-5943

$\rightarrow$

WATER POLLUTION CONTROL

Glen H. Fiedler, Supervisor

Water Quality Management Division

Office of Water Programs

Department of Ecology

Mail Stop PV-11

Olympia, WA 98504

(206) $753-2971$

WATER RESOURCES

Gene Wallace, Supervisor

Water Resources Management

Division

Óf fice of Water Programs

Department of Ecology

Mail Stop PV-11

Olympia, WA 98504

(206) 753-2829

WELFARE

Glen Miller, Assistant Secretary of Community Services

Department of Social and Health Services

Office Bldg. 2

Mail Stop OB-42

Olympia, WA 98504

(206) 753-1034

WORKMEN'S COMPENSATION

Charles F. Murfuy, Assistant

Director for Industrial

Insurance

Department of Labor and Industries

General Administration Bldg.

Olympia, WA 98504

(206) 753-6308 
State senators are elected for 4-year terms. Approximately half of them are chosen at each of the biennial elections held in even-numbered years concurrently with the national general elections. All representatives are elected for 2-year terms. The regular sessions of the legislature convene on the second Monday in January in odd-numbered years and are 1 imited by the constitution to not more than 60 days. Special or extraordinary legislative sessions may be called by the Governor.

Both the State Senate and House of Representatives have formed energy comnittees to research the problems of energy in Washington. An initiative (383) was voted upon in November 1980 and passed. This legislation bans the disposal of all out-of-state radioactive wastes (except medical wastes) in the State of Washington, unless Washington has a compact with the shipping state. Other than initiative 383, only minor, unsubstantial changes have been made to state regulations concerning the disposal and transportation of radioactive materials. (6)

\subsubsection{Judicial Branch}

The Washington Constitution provides for one state supreme court and a superior court in each county. The Supreme Court of Washington consists of nine judges elected on a nonpartisan ballot; three every two years for a 6-year term. The court hears appeals from lower courts and may exercise original jurisdiction in certain cases. The supreme court also has the power to issue writs of review, prohibition, and all other writs necessary to fulfill its appellate and revisory jurisdiction. (5)

There are 39 superior courts in washington (one for each county) and 27 judicial dist:icts. Superior court judges are elected in a general election for a 4-year term, and may serve in any of the 39 courts. The total number of superior court judges is determined by population. The superior courts have original jurisdication in all cases involving the title or possession of property, or the legality of any tax, assessment toll or municipal fine in which the demand exceeds $\$ 1,000$. The court also has jurisdiction on all cases of misdemeanor, criminal cases amounting to felony, all matters of divorce or annulment of marriage, all actions of forceable entry and of actions to prevent or abate a nusiance. (5) 
The constitution also provides for justice courts (held by a justice of the peace), and a Washington Court of Appeals. The justices of the peace have original jurisdication in cases where the demand of value does not exceed $\$ 1,000$ and the court of appeals has the authority to review superior court actions. (5)

\subsubsection{Statutory Regulations}

The Nuclear Energy and Radioactive Legislation, Chapter 70.98 RCW, establishes the radiation control program in the state of Washington and is presented in Appendix B. This legislation designates the Department of Social and Health Services as the state radiation control agency, created the Advisory Council on Nuclear Energy and Radiation, and assigned the Department of Commerce and Economic Development, Office of Nuclear Energy Development, the responsibility of nuclear energy research, development, and education in the state. In addition, the legislation establishes the procedure and requirements for the licensing and inspections of sources of ionizing radiation, as well as the establishment of training programs and administrative procedure for personnel who work with sources of ionizing radiation, $(6,8)$

\subsection{FEDERAL ACTIVITIES IN THE STATE OF WASHINGTON}

Apart from the Nuclear Regulatory Commission's inspection of the Nuclear Engineering Radioactive. Waste Disposal Facility, federal activities in the State of Washington currently center on the thermodynamic studies conducted at Hanford. This research concerns the possible disposal of high-level nuclear waste in lava rock. (6)

\subsection{INTEREST GROUPS}

Many interest groups concerned with nuclear issues and radioactive wastes have offices in Washington. In addition, there are many groups generally concerned with the environment who may become actively involved in nuclear energy and waste management issues if they view the issues as detrimental to their environmental interests. Following is a list of some of the major energy and environmental ofganizations located in Washington and their specific areas of concern. $(10,11,12)$ 
Friends of the Earth: Committed to the "preservation, restoration and rational use of the earth." Some of their interests concern the issues of nuclear power safety, strip mining, energy conservation, and water pollution.

Mercer Island Environmental Council: Concerned with the impact of modern man's civilization and technology upon his environment, and encourages the protection and restoration of man's ecological, natural, and historical heritage through creative planning and education.

Northwest Fund for the Environment: Interested in pursuing environmental quality through research, publicity, education, and litigation on a regional basis.

Pacific County Environmental Council: Concerned with the environmental problems of Pacific County; reviews environmental impact statements and advises county and state officials on environmental issues.

The People/Natural Resources Research Council: Concerned with increasing an understanding of the interrelationship between Man and his environment and in improving natural resource management policies.

Protect the Peninsula's Future: Concerned with land use on the North Olympic Peninsula, and actively opposed proposals for a nuclear plant and an oil superport on the Peninsula.

Save Skagit Bay: Opposes construction of a nuclear facility on skagit Island, skagit County. In general, the group is concerned with preserving the residential, agricultural and recreational activities adjacent to skagit Bay.

Sierra Club, Pacific Northwest Chapter: The Sierra Club's Energy Committee advocates a moratorium on the further construction of nuclear plants. In general, the club is concerned with the natural environment and protecting it from the adverse impacts of Man and his society.

Skagitarians Concerned About Nuclear Plants (SCANP): Actively opposes the construction of a nuclear facility in skagit County. 
Tri Cities Nuclear Council: Local agency interested in nuclear activities occurring in the Hanford region of Washington.

Washington Environmental Council, Inc.: Interested in promoting citizen, legislative, and administrative action toward providing a better environment.

Washington Environmental Health Association: A group of professionals interested in radiological health, air and water pollution control, solid waste management, community planning, and industrial hygiene.

\subsection{PRINTED MEDIA}

The 25 newspaper articles presented in Appendix $C$ represent a 2-week search of 2 major newspapers in the State of Washington. This search was not intended to be all-encompassing nor representative of the major issues of concern in Washington. The issues reviewed produced nine articles specifically related to low-level waste disposal, whereas the remaining articles deal with the broad subject of nuclear power. Together, the articles are intended to present a general indication of the coverage of radiation issues by printed media in the state:

In addition to the articles in Appendix $C$, both newspapers have printed editorials concerning nuclear energy and nuclear wastes, which may further indicate the media's coverage of these issues in Washington. Within the last year, the Spokane Review has printed 4 editorials and the Seattle Times has printed approximately 16 editorials pertaining to these two topics. Neither newspaper, howéver, has recently conducted a poll or survey concerning nuclear power or radiation issues. $(13,14,15)$ 
REFERENCES

1. "Telephone Directory and Committee Assignments of the Senate and House of Representatives," State of Washington, 47th Legislature, Olympia, Washington, 1981 .

2. Personal communication with Wilson Smith, member of Senator Henry Jackson's staff, November 30, 1979.

3. Standing Committee of the House of Representatives of the United States, Ninety-Seventh Congress. U.S. Government Printing office, Washington, D.C., 1980.

4. List of Standing Committees of the Senate of the United States for the Ninety-Seventh Congress. U.S. Government Printing office, Washingtọn, D.C., 1980 .

5. "The Constitution of the State of Washington as Amended." Office of Secretary of State, State of Washington, Olympia, Washington, undated.

6. Personal communication with David Stephens, member of Governor John Spellman's staff, September 18, 1981.

7. "Uffice of the Attorney General." Office of the Attorney General, State of Washington, Olympia, Washington, 1973.

8. "Nuclear Energy and Radiation Legislation, Chapter 70.98 RCW." Washington Department of Social and Health Services, Radioactive Materials Cnntrol Unit, olympia, Washington, undated.

9. The National Directory of State Agencies, 1978-1979. Information Resources Press, Washington, D.C., 1978.

10. Thaddeus, C. Tryna and Sally R. Osberg, Environmental Protection Directory. Marques Academic Press, Chicago, Illinois, 1975. 
11. Onyx Group, Inc., Environment U.S.A., A Guide to Agencies, People, and Resources. R. P. Bowker Co., New York, N.Y., 1974.

12. Center for California Public Affairs, Directory of Consumer Protection and Environmental Agencies. Academic Press, Orange, New Jersey, 1973.

13. Personal communication with Beverly Russe11, Seattle Times, August 26, 1980.

14. Personal communication with Bill Young, GMA Research Inc,, August 27, 1980.

15. Personal communication with Sarah Lindgren, Spokane Review, August 26, 1980. 
5. SURVEY METHODOLOGY

A direct mail survey was conducted during September 1979 of all Radioactive Material License holders in the state of Washington. Names of license holders were obtained from the Washington Radioactive Materials Control Unit. The questionnaire used is presented in Figure 5- 1 . This "free form" questionnaire was developed to solicit basic information necessary to generally characterize the low-level radioactive waste management practices. Questions asked were limited to those which have a direct bearing on the overall characterization of practices within the state, rather than on a detailed characterization of each facility.

Each questionnaire was sent with a transmittal letter (see Figure 5-2), general instructions (see Figure 5-3), and a return envelope. Responses were first evaluated to determine the information presented in Appendix $A$, List of Radioactive Material Licensees. If a response was not received, classification of "type of facility" was determined from the licensee name, if possible; if not, they were classified as "unknown." The responses received were then transposed onto a "fixed form" survey form (see Figure 5-4) which was developed based on analysis of the "free form" responses given in Figure 5-1. The information provided by the licensees was then tabulated in the formats presented in sections 2 and 6 of this briefing book. 
FIGURE 5-1

NUS RADIOACTIVE WASTE SURVEY

FACILITY NAME:

STREET AQDRESS:

CITY/STATE/ZIP:

TELEPHONE NO:

PERSON CONTACTED/TITLE:

TYPE OF FACILITY:

\begin{tabular}{l}
$\square$ ACADEMIC \\
$\square$ OTHER DESCRIBE \\
\hline
\end{tabular}

SIZE OF FACILITY: STUDENTS BEDS EMPLOYEES

PROCESS(ES) WHICH GENERATE WASTE:

IS WASTE TREATED BEFORE PACKAGING?

HOW?

HOW IS WASTE PACKAGED?

WHAT IS PRINCIPAL CHEMICAL \& PHYSICAL COMPOSITION OF WASTE'?

HOW MANY WASTE SHIPMENTS DID YOU MAKE IN:

1978 -

$197,-$

$1976-$

DO YOU EXPECT INCREASE OR DECREASE IN WASTE VOLUME?

PLEASE QUANTIFY WASTE DISPOSED OF IN CALENDAR YEARS 1978, 1977, 1976 ON REVERSE SIDE OF FORM. IF MORE SPACE WILL BE REQUIRED THAN IS AVAILABLE ON FORM, PLEASE PROVIDE IN SAME FORMAT ON BLANK SHEET OF PAPER. 
FIGURE 5-1 (Concluded)

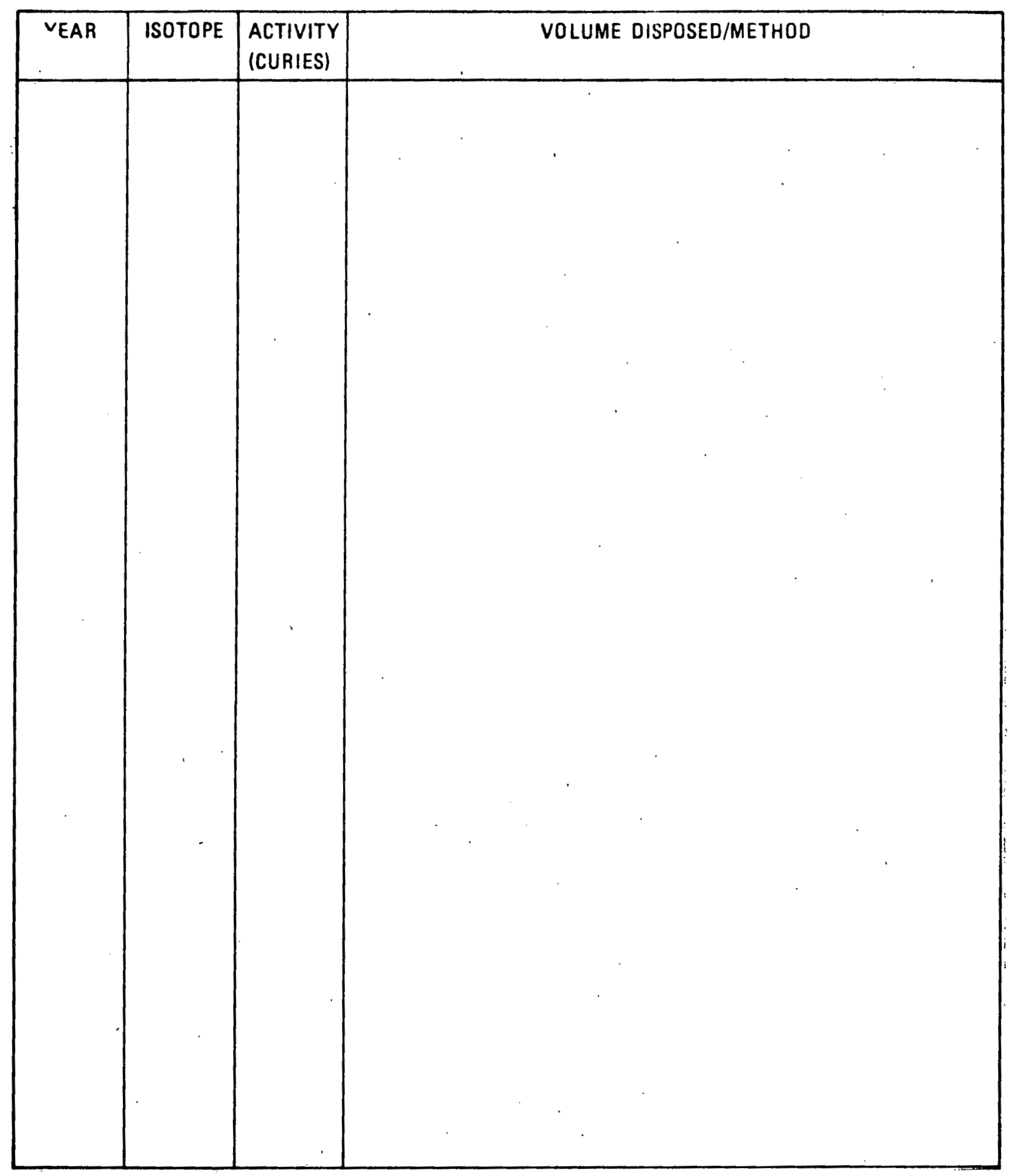

ADDITIONAL COMMENTS: 
FIGURE 5-2

\section{TRANSMITTAL LETTER}

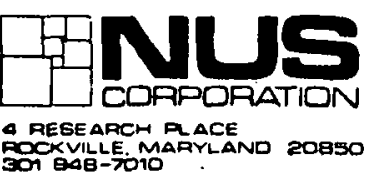

September 11, 1979

BDG-PE-275

8t. Judith's Bospital

600 Beauregard Avenue

Danville, Illinois 61832

Attn: Dr. J. M. Wilson

Subject: survey of Low Lovel Radioactive Waste Dibposal

Dear Dr. Wilson:

Maintaining free access to proper low level radioactive waste disposal sites is becoming more difficult as individual atate and local jurisdictions seek to impose control upon or eliminate such activity.

Nus corporation is conducting a survey of nuclear material licensees for BGsG Idaho and the Department of Energy to ascertain the volume and nature of waste they generate. At the present time there is not an available data base for the long range projections necessary for proper planning of future low lovel wacto dioposal tacilitles.

Completion of the attached survey form will enable wus to generate such a data base for the U.S. Covernment. Your cooperation will assist both your organization and other users of radioactive materials in maintaining continued access lu approprlare waste disposal facilities.

If you have any questions on the attached survey form or its use, please feel free to contact we at 301/948-7010.

sincerely,

Bruce D. Guilbeault

Project Manager

BDG : dg

Bnclosure 
FIGURE 5-3

\section{GENERAL INSTRUCIIONS}

1. The enclosed Rodioactive Weste Survey fom us is self-explanatory. The following instructions provide general guldelines. If you have emy specific concerns. please cell Bruce Gulbeault or Don Elll on

$$
301-948-7020
$$

2. If posslble, all quantitative date should be taken directly tom abjpmem records. If this is not proctlcal, please estimate answers as eccurately as posslble.

3. Pleese explaln or speclfy answers (where requested) es completely as possible. If odditional space is needed. please use the "Additional Comments" section on the lest page of this questionneire.

4. When you hove completed this questlonnaise, please retura it in the enclosed stemped, self-addressed envelope.

5. If your ftellity does not dis pose of Radlosctive Materlels by use of the connerctal redioactive material disposal sites. please fill out the $s$ irvey form with the amoust of materlal recelved in each year and where these Radipactive Materals recelved were disposed (e.o. Isotopes used in patjent teatment residues decayed to background, disposed in trash, or shpped out in finlshed products .)

\section{IFANX YOU VERY MUCH FOR YOUR CO-OPERATION}


FIGURE 5-4.

FORM USED FOR TABULATION

LICENSEE NAME

NAME OF FACILITY

STREET ADDRESS

CITY/STATE/ZIP

TELEPHONE NO.

PERSON SUPPLYING INFOR MATION

$\div \quad 1$

TITLE

PART I - TYPE OF FACILITY

(CHECK THE ONE CATECORY WHICH IS MOST APPLICABLE)

MEDICAL

DOSPITAL

D PHARMACEUTIC.AL MANUFACTURER

$\square$ MEDICAL RESEARCH/EDUCATION

$\square$ OTHER (SPECIFY)

EDUCATIONAL

$\square$ UNIVERSITY

DIGH SCHOOL

$\square$ OTHER (SPECIFY)
INDUSTRIAL

D INCORPORATES RADIOACTIVITY INTO PRODUCTS

$\square$ USES RADIOACTIVITY IN PROCESS CONTROL

D COMMERCIAL POWER REACTOR

$\square$ OTHER (SPECIFY)

GOVERNMENTAL (NONMEDICA $L$ OR EDUCATIONAL)

$\square$ FEDERAL

D MLLLTARY

DTATE

$\square$ LOCIL

PART I - DISPOSAL METHOD

CHECK EACH DISPOSAL METHOD WHICH YOU DO EMPLOY

D SHIP TO COMMERCIAL REPOSITORY

D RELEASE TO SEWER

$\square$ COMBINE WITH COMMON REFUSE

D VENT TO ATMOSPHERE

$\square$ BURY ON-SITE

$\square$ RETURN TO VENDOR

D DISTRIBUTE IN PRODUCT FORM

$\square$ NO WASTE CENERATED

$\square$ OTHER (SPECIFY) 
FIGURE 5-4 (Continued)

PART II - SOURCE OF RADIOACTIVE WASTE

(CHECK EACH SOURCE OF YOUR POTENTIAL RADIOACTIVE WASTE AND, IF YOU SHIP, INDICATE TME PERCENTAGE OF YOUR TOTAL SHIPPED WASTE VOLUME ORICINATING FROM EACH SOURCE CATEGORY)

SOURCE OF RADIOACTIVITY

PERCENT OF WASTE

VOLUME SHIPPED

D NUCLEAR REACTOR

D NEUTRỌN GENERATOR

D CYCLOTRON OR SYNCHROTRON

D SEALED SOURCE

$\square$ UNSEALED RADIOACTIVE MATERIAL

D NATURAL ORES OR MILL TARINGS

$\square$ OTHER (SPECIFY)

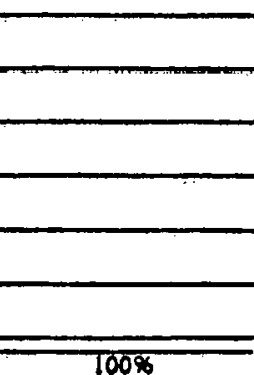

IF YOU DO NOT SHIP RADIOACTIE WASTES. YOU HAVE COMPLETED THE QUESTIONNAIRE THANK YOU. IF YOU DO SHIP, PLEASE CONTINUE WITH THE FOLLOWINC QUESTIONS.

PART IV - PHYSICAL FORM OF SHIPPED UASTES

(CHECK EACH FORM OF WASTE WHICH YOU SHIP AND INDICATE THE PERCENTACE OF YOUR TOTAL SHIPPED WASTE VOLUME REPRESENTING EACH FORM)

PERCENT OF WASTE

VOLUME SHIPPED

DRY SOLIDS. TRASH, IRRADIATED COMPONENTS

SOLIDIFIED OR ABSORBED LIQUIDS, SOLID SLUDGES, SPENT RESINS, FILTER SLUDGES OR EVAPORATOR BOTTOMS

D animal carcasses or other biolocical waste

D SEALED SOURCES

D OTHER (SPECIFY)

DOES WASTE CONTAIN ANY MATERIAL WHICH IS POTENTIALLY:

$\begin{array}{lll}\text { YES } & \text { NO } \\ \square & \square & \text { COMBUSTIBLE } \\ \square & \square & \text { EXPLOSIVE } \\ \square & \square & \text { CHEMICALLY TOXIC }\end{array}$

WHAT SHIPPING CONTAINERS DO YOU USE?
口 33 CALLON STEEL DRUMS
30 CALLON STEEL DRUMS
OT OTHER (SPECIFY)

VHAT ON-SITE PROCESSING OF WASTE DO YOU EMPLOY?

$\square$ IHONE
$\square$ MECHANICAL COMPACTION
$\square$ INCINERATION
$\square$ SOLIDIFICATION OR EVAPORATION OF LIQUIDS
$\square$ ABSORPTION OF LIQUIDS
$\square$ OTHER (SPECIFY)


FIGURE 5-4 (Concluded)

PART V - WASTE QUANTITY

INDICATE TOTAL YEARLY VOLUME (IN CUBIC FEET) OF WASTE SHIPPED TO A COMMERCLAL DISPOSAL FACILITY.

\section{CUBIC FEET SHIPPED}

ACTUAL SHIPPED IN 1977

ACTUAL SHIPPED IN 1978

ACTUAL SHIPPED IN 1979

INDICATE TOTAL YEARLY VOLUME (IN CUBIC FEET) OF WASTE PROJECTED TO BE GENERATED WHICH WILL BE SHIPPED.

\section{CUBIC FEET GENERATED}

ESTIMATED GENERATION IN 1980

ESTIUATED GENERATION IN 1989

ESTIMATED GENERATION in 1990

INDICATE THE QUANTITY OF RADIOACTIVITY (IN CURIES) SHIPPED TO A COMMERCIAL FACILITY IN THE YEARS 1977,1978 AND 1979.

\begin{tabular}{|l|c|c|c|}
\hline \multirow{2}{*}{ ISOTOPE } & \multicolumn{3}{|c|}{ QUANTTY SHIPPED (CURIESI IN: } \\
\cline { 2 - 4 } & 1977 & 1978 & 1979 \\
\hline & & & \\
\hline & & & \\
\hline & & & \\
\hline & & & \\
\hline & & & \\
\hline & & & \\
\hline & & & \\
\hline & & & \\
\hline & & & \\
\hline & & & \\
\hline
\end{tabular}




\subsection{USE OF COMMERCIAL LOW-LEVEL WASTE DISPOSAL FACILITIES}

In the State of Washington, a total of 312 potential shippers of low-level radioactive waste were identified. These potential shippers were sent, by direct mail, questionnaires concerning their waste management practices. The respondent was identified as either a medical, educational, industrial, power reactor, or governmental type facility. All but five of the potential shippers identified for the state of Washington were able to be grouped into one of these classifications of facilities. Section 2.0 presents the number of respondents using various disposal methods and the source of radioactivity used at facilities. Table 2-1 indicates that 11.8 percent (20 facilities) of the respondents use commercial low-level waste facilities. The following subsections present a sumary of the characteristics and quantity of wastes disposed of by these 20 facilities.

\subsection{RESPONSE TO SURVEY}

Table 6-1 presents, by facility type, the number of potential shippers surveyed, the total number and percentage of responses obtained, and a breakdown of responses by degree of response. If a facility provided at least the facility type and method of disposal, the answers were considered a response. If no information was obtained, the type of facility was determined by the facility name. The responses were further categorized by degrec of reoponse into three groups. Gioup 1 iew sponses were responses in which all appropriate information requested was provided (see Figure 5-1). Group 2 responses provided only information on the type of facility, disposal method, and quantity of waste. Group 3 responses included only information on the type of facility and the disposal method.

Fifty-four percent of all potential shippers ldentified provided some degree of response. There was no great disparity in percent of response between type of facility, with the range being 50.0 percent for medical facilities to 74.4 percent for government facilities. Of the respondents, only 10.0 percent provided all requested information.

It should be noted that of the 143 potential shippers (out of 312) which did not provide any information, many of these may in fact be shippers. A decline to return the questionnaire can be reasonably assumed to indicate that they in fact do 
ship wastes, since the only response and effort required if they do not ship wastes is to answer "no.". Accordingly, there is a high potential that the percent response to the survey from shippers may be as low as 12 percent (20 shipper respondents out of a total of 163 shippers or nonrespondents) rather than the 54 percent response from all potential shippers.

\subsection{SOURCES OF SHIPPED WASTE}

\subsubsection{Distribution by Type of Facilities Shipping wastes}

Table 6-2 presents the distribution of numbers of facilities shipping wastes by major type of faility and by subgroup within each major type. In terms of number of facilities shipping wastes, medical, educational, and industrial facilities account for about 30 percent each of all shippers, with governmental facilities comprising 10 percent of all shippers.

\subsubsection{Origin of Radioactivity Resulting in Shipped Wastes}

The origin of radioactivity resulting in shipped waste was grouped into four categories: nuclear reactor operation, purchased as sealed sources, purchased as unsealed radioactivity, and produced by a netron generator. Table 6-3 presents the distribution of number of facilities shipping wastes according to type of facility and origin of radioactivity. It should be noted that more than one origin may be appropriate for a given facility. Therefore, the total number of origins presented in Table 6-3 is greater than the total number of shippers of low-level waste. Over 90 percent of the facilities shipping waste obtain the radioactivity as unsealed radioactive material.

\subsection{VOLUME OF SHIPPED WASTE}

Volumes of low-level wastes shipped to commercial disposal facilities were provided by 13 facilities of the 20 respondents that indicated they shipped wastes. These 13 facilities represent 8 percent of the 163 potential shippers within the state (20 respondents and 143 non-respondents). Table 6-4 presents volumes of shipped wastes for the years 1976, 1977, and 1978 for each type of facility. 
Table 6-5 shows the number of facilities that expect to increase, decrease, or not change the volume of shipped waste. These data indicate that a small increase with time might be expected.

\subsection{ACTIVITY OF SHIPPED WASTE}

Table 6-6 presents quantity of activity in the waste shipped for the years 1976, 1977, and 1978 for each type of facility.

Table 6-7 presents the distribution of activity by shipped radionuclide.

\subsection{PHYSICAL CHARACTERISTICS OF SHIPPED WASTE}

Onsite processing of low-level waste may be performed to either reduce the volume of the waste (compaction, incineration) or to remove free liquid (solidification, evaporation, absorption). Table 6-8 shows the number of facilities using these methods. Only two of the 17 respondents indicated they used mechanical compaction or incineration for volume reduction. Over half of the facilities use absorption to handle free liquids.

Table 6-9 presents the type of shipping container used onsite to package waste for transport to disposal facilities. Most facilities use either 55-gallon or 30gallon steel drums. However, 50 percent of the facilities (shown under "other" column) use simply cardboard boxes for small volumes of waste which are packaged in drums by the transporter.

Shipped waste was categorized as either dry, moist, biological, sealed, or other. Table 6-10 presents the number of facilities shipping waste in any of these categories. 
TABLE 6-1

RESFONSE TO DIRECT MAIL SURVEY

\begin{tabular}{|c|c|c|c|c|c|c|c|c|c|c|c|c|}
\hline \multirow[b]{3}{*}{$\begin{array}{c}\text { Type } \\
\text { of } \\
\text { facility }\end{array}$} & \multirow[b]{3}{*}{$\begin{array}{c}\text { Number } \\
\text { of } \\
\text { licen- } \\
\text { sees } \\
\end{array}$} & \multirow[b]{3}{*}{$\begin{array}{c}\text { Number } \\
\text { of } \\
\text { respon- } \\
\text { dents }\end{array}$} & \multirow[b]{3}{*}{$\begin{array}{l}\text { Percent } \\
\text { respons? }\end{array}$} & \multicolumn{9}{|c|}{ Degree of Response } \\
\hline & & & & \multicolumn{3}{|c|}{ Group 1} & \multicolumn{3}{|c|}{ Group 2} & \multicolumn{3}{|c|}{ Group 3} \\
\hline & & & & Numbər & $\begin{array}{c}\text { Percent } \\
\text { of } \\
1 \text { icen- } \\
\text { sees }\end{array}$ & $\begin{array}{l}\text { Percent } \\
\text { of } \\
\text { respon- } \\
\text { dents }\end{array}$ & Number & $\mid \begin{array}{c}\text { Percent } \\
\text { of } \\
1 \text { icen- } \\
\text { sees }\end{array}$ & $\begin{array}{c}\text { Percent } \\
\text { of } \\
\text { respon- } \\
\text { dents }\end{array}$ & Number & $\begin{array}{c}\text { Percent } \\
\text { of } \\
\text { licen- } \\
\text { sees }\end{array}$ & $\begin{array}{c}\text { Percent } \\
\text { of } \\
\text { respon- } \\
\text { dents }\end{array}$ \\
\hline Medical & 108 & 54 & 50.0 & 9 & 2.9 & 5.3 & 41 & 13.1 & 24.3 & 4 & 1.3 & 2.4 \\
\hline Educational & 21 & 13 & 61.9 & $\mathbf{J}$ & 1.0 & 1.8 & 8 & 2.6 & 4.7 & 2 & 0.6 & 1.2 \\
\hline Industrial & 139 & 73 & 52.5 & 13 & 4.2 & 7.7 & 60 & 19.2 & 35.5 & 0 & 0.0 & 0.0 \\
\hline Power Reactor & 0 & - & - & - & - & - & - & - & - & - & - & - \\
\hline Governmental & 39 & 29 & 74.4 & $\Xi$ & 0.6 & 1.2 & 26 & 8.3 & 15.4 & 1 & 0.3 & 0.6 \\
\hline Unknown & 5 & - & - & - & - & - & - & - & - & - & - & - \\
\hline TOTAL & 312 & 169 & 5.4.? & 27 & 8.7 & 10.0 & 135 & 43.3 & 79.9 & 7 & 2.2 & 4.1 \\
\hline
\end{tabular}


TABLE 6-2

TYPE OF FACILITIES SHIPPING LOW-LEVEL WASTE

\begin{tabular}{|c|c|c|c|c|}
\hline \multicolumn{2}{|c|}{ Type of Facility } & \multirow{2}{*}{$\begin{array}{l}\text { Number of } \\
\text { facilities } \\
\text { shipping }\end{array}$} & \multirow{2}{*}{$\begin{array}{l}\text { Percent } \\
\text { of all } \\
\text { shippers }\end{array}$} & \multirow{2}{*}{$\begin{array}{c}\text { Percent } \\
\text { of } \\
\text { facilities type }\end{array}$} \\
\hline Facility & Subgroup & & & \\
\hline Medical & $\begin{array}{c}\text { Hospital } \\
\text { Pharmaceutical } \\
\text { Research/Education } \\
\text { Other } \\
\text { Total }\end{array}$ & $\begin{array}{l}2 \\
0 \\
3 \\
1 \\
\end{array}$ & $\begin{array}{r}10.0 \\
0.0 \\
15.0 \\
5.0 \\
30.0\end{array}$ & $\begin{array}{r}33.3 \\
0.0 \\
50.0 \\
16.7 \\
100.0\end{array}$ \\
\hline Eđucational & $\begin{array}{l}\text { University } \\
\text { High School } \\
\text { Other } \\
\text { Total }\end{array}$ & $\begin{array}{r}5 \\
0 \\
0 \\
\end{array}$ & $\begin{array}{r}25.0 \\
0.0 \\
0.0 \\
25.0\end{array}$ & $\begin{array}{r}100.0 \\
0.0 \\
0.0 \\
100.0\end{array}$ \\
\hline Industrial & $\begin{array}{l}\text { Product Use } \\
\text { Process Control } \\
\text { Other } \\
\text { Total }\end{array}$ & $\begin{array}{l}2 \\
3 \\
2 \\
7\end{array}$ & $\begin{array}{l}10.0 \\
15.0 \\
10.0 \\
\\
35.0\end{array}$ & $\begin{array}{r}28.6 \\
42.9 \\
28.6 \\
\end{array}$ \\
\hline Power Reactor & Total & 0 & - & - \\
\hline Governmental & $\begin{array}{l}\text { Federal } \\
\text { Military } \\
\text { State } \\
\text { Local } \\
\text { Total }\end{array}$ & $\begin{array}{l}0 \\
1 \\
1 \\
0 \\
\\
2\end{array}$ & $\begin{array}{l}0.0 \\
5.0 \\
5.0 \\
0.0 \\
10.0\end{array}$ & $\begin{array}{r}0.0 \\
50.0 \\
50.0 \\
0.0 \\
100.0\end{array}$ \\
\hline TOTAL & & 20 & 100.0 & 100.0 \\
\hline
\end{tabular}


TABLE 6-3

ORIGIN OF RADIOACTIVITY RESULTING IN SHIPPED WASTES

\begin{tabular}{|c|c|c|c|c|c|c|c|c|c|}
\hline \multirow[b]{2}{*}{$\begin{array}{c}\text { Type } \\
\text { of } \\
\text { facility }\end{array}$} & \multirow[b]{2}{*}{$\begin{array}{l}\text { Number } \\
\text { of } \\
\text { respon- } \\
\text { dents }\end{array}$} & \multicolumn{2}{|c|}{$\begin{array}{l}\text { Nuclear } \\
\text { reactor }\end{array}$} & \multicolumn{2}{|c|}{$\begin{array}{c}\text { Sealed } \\
\text { sources }\end{array}$} & \multicolumn{2}{|c|}{$\begin{array}{l}\text { Unsealed } \\
\text { radioactive } \\
\text { material }\end{array}$} & \multicolumn{2}{|c|}{$\begin{array}{l}\text { Neutron } \\
\text { generator }\end{array}$} \\
\hline & & $\begin{array}{l}\text { Mumber } \\
\text { of } \\
\text { sourcest }\end{array}$ & $\begin{array}{l}\text { Percert } \\
\text { of all } \\
\text { shippe:s }\end{array}$ & $\begin{array}{c}\text { Number } \\
\text { of } \\
\text { sources }\end{array}$ & $\begin{array}{l}\text { Percent } \\
\text { of all } \\
\text { shippers }\end{array}$ & $\begin{array}{c}\text { Number } \\
\text { of } \\
\text { sources" }\end{array}$ & $\begin{array}{c}\text { Percent } \\
\text { of all } \\
\text { shippers }\end{array}$ & $\begin{array}{l}\text { Number } \\
\text { of } \\
\text { sources }\end{array}$ & $\begin{array}{l}\text { Percent } \\
\text { of all } \\
\text { shippers }\end{array}$ \\
\hline Medical & 6 & 0 & 0.0 & 1 & 5.0 & 6 & 30.0 & 0 & 0.0 \\
\hline Educational & 5 & $i$ & 5.0 & 1 & 5.0 & 4 & 20.0 & & \\
\hline Industrial & 7 & 0 & 0.0 & 1 & 5.0 & 7 & 35.0 & 1 & .5 .0 \\
\hline Power Reactor & 0 & - & - & - & - & - & - & - & - \\
\hline Jovernmental & 2 & 1 & 5.0 & 0 & 0.0 & 1 & 5.0 & 0 & 0.0 \\
\hline TOTAL & 20 & 2 & 10.0 & 3 & 15.0 & 18 & 90.0 & 1 & 5.0 \\
\hline
\end{tabular}

*The total of "number of sources" exceeds the sotal number of respondents due due to facilisies generating waste from several sources. 
TABLE 6-4

VOLUME OF SHIPPED WASTE

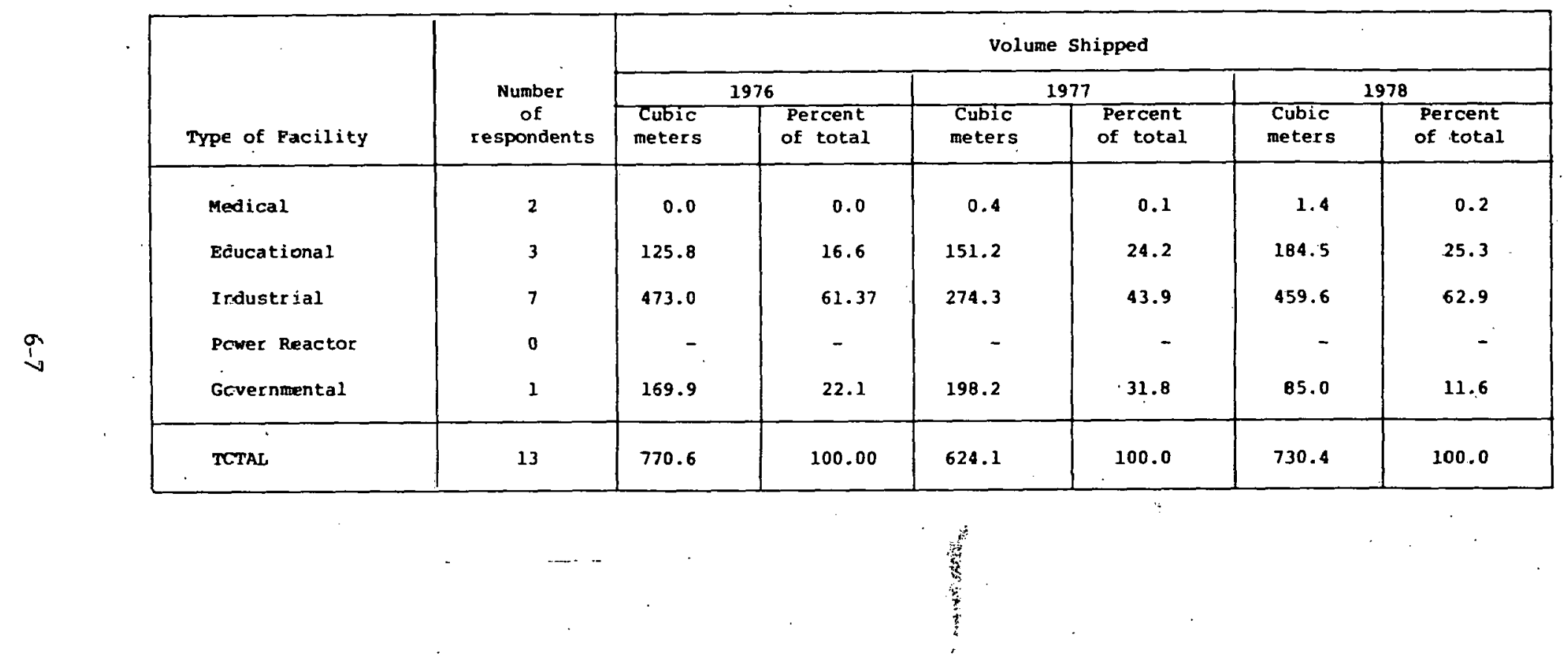


TABLE 6-5

PRDJECTED CEANGE IN VOLUME OF SHIPPED WASTE

\begin{tabular}{|c|c|c|c|c|c|c|c|c|}
\hline & \multirow[b]{3}{*}{ Type of Facility } & \multirow[b]{3}{*}{$\begin{array}{l}\text { Number } \\
\text { of } \\
\text { respon- } \\
\text { dents }\end{array}$} & \multicolumn{6}{|c|}{ Projected Change in volume } \\
\hline & & & \multicolumn{2}{|c|}{ Inctease } & \multicolumn{2}{|c|}{ No Cr:ange } & \multicolumn{2}{|c|}{ Decrease } \\
\hline & & & $\begin{array}{c}\text { Number } \\
\text { of } \\
\text { faci-ities }\end{array}$ & $\begin{array}{l}\text { Percent } \\
\text { of total } \\
\text { respon- } \\
\text { dents }\end{array}$ & $\begin{array}{c}\text { Number } \\
\text { of } \\
\text { facilities }\end{array}$ & $\begin{array}{l}\text { Percent } \\
\text { of total } \\
\text { respon- } \\
\text { dents }\end{array}$ & $\begin{array}{c}\text { Number } \\
\text { of } \\
\text { facilities }\end{array}$ & $\begin{array}{l}\text { Percent } \\
\text { of total } \\
\text { respon- } \\
\text { dents }\end{array}$ \\
\hline \multirow{6}{*}{$\begin{array}{c}\infty \\
1 \\
\infty\end{array}$} & Medical & 4 & 2 & 13.3 & 2 & 13.3 & 0 & - \\
\hline & Educational & 3 & $\mathbf{0}$ & - & 2 & 13.3 & 1 & 6.7 \\
\hline & Industrial & 8 & 6 & 10.0 & 2 & 13.3 & 0 & - \\
\hline & Power Reactor & - & - & - & - & - & - & - \\
\hline & Governmental & 0 & - & - & - & - & - & - \\
\hline & TOTAL & 15 & .8 & 53.3 & 6 & 40.0 & 1 & 6.7 \\
\hline
\end{tabular}


TABLE 6-6

ACTIVITY OF SHIPPED WASTE

\begin{tabular}{|c|c|c|c|c|c|c|c|c|}
\hline & \multirow[b]{3}{*}{ Type of Facility } & \multirow{3}{*}{$\begin{array}{l}\text { Number } \\
\text { of } \\
\text { respon- } \\
\text { dents }\end{array}$} & \multicolumn{6}{|c|}{ Activity Shipped } \\
\hline & & & \multicolumn{2}{|c|}{1976} & \multicolumn{2}{|c|}{1977} & \multicolumn{2}{|c|}{1978} \\
\hline & & & Curies & $\begin{array}{l}\text { Percent } \\
\text { of total }\end{array}$ & Curies & $\begin{array}{l}\text { Percent } \\
\text { of total }\end{array}$ & Curies & $\begin{array}{l}\text { Percent } \\
\text { of total }\end{array}$ \\
\hline & Medical & 2 & 0.0 & 0.0 & $9.0 \mathrm{E}-3$ & 0.1 & $2.6 \mathrm{E}-2$ & 0.0 \\
\hline \multirow{2}{*}{$\hat{0}$} & Educational & 4 & $7.0 \mathrm{E}-3$ & 0.0 & $5.0 E-3$ & 0.1 & $6.6 E+2$ & 29.8 \\
\hline & Industrial & 7 & $4.2 E+3$ & 99.8 & $6.2 E+0$ & 55.4 & $1.6 \mathrm{E}+3$ & 70.1 \\
\hline \multirow[t]{4}{*}{. } & Power Reactor & 0 & - & - & - & - & - & - \\
\hline & Governmental & 1 & $1.0 \mathrm{E}+1$ & 0.2 & $5.0 \mathrm{E}+0$ & 44.4 & $3.0 E+0$ & 0.1 \\
\hline & TOTAL & 14 & $4.2 E+3$ & 100.0 & $1.1 E+1$. & 100.0 & $2.2 \mathrm{E}+3$ & 100.0 \\
\hline & & . & & & & & & 辤 \\
\hline
\end{tabular}


Table 6-7

RADIONUCLIDES IN SHIPPED WASTES

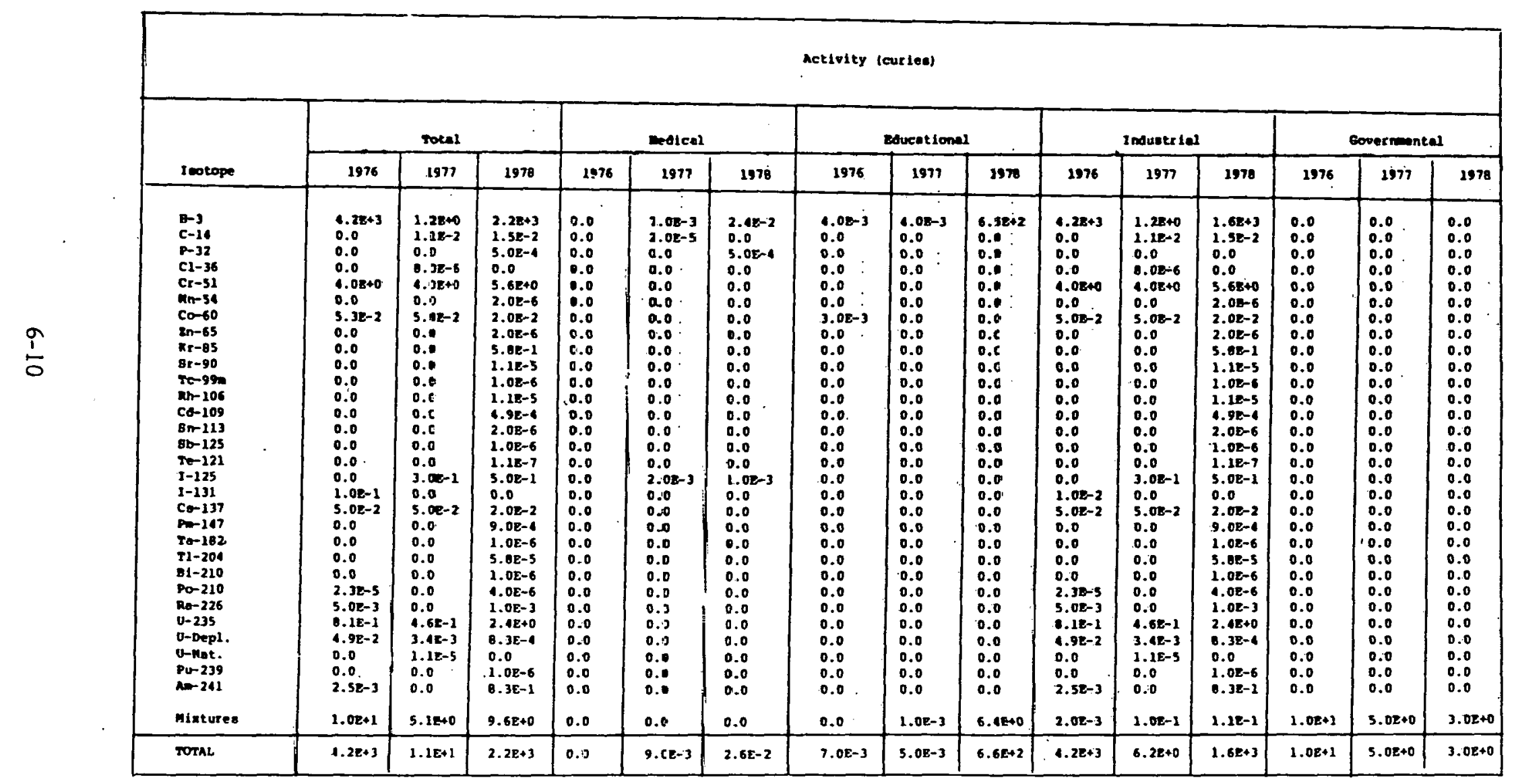


TABLE 6-8

ONSITE PROCESSING OF SHIPPED WASTE

\begin{tabular}{|c|c|c|c|c|c|c|c|}
\hline \multirow[b]{2}{*}{$\begin{array}{c}\text { Type } \\
\text { of Facility }\end{array}$} & \multirow[b]{2}{*}{$\begin{array}{l}\text { Number of } \\
\text { respondents }\end{array}$} & \multicolumn{2}{|c|}{$\begin{array}{l}\text { Mechanical } \\
\text { Compaction }\end{array}$} & \multicolumn{2}{|c|}{$\begin{array}{l}\text { Solidification } \\
\text { Evaporation }\end{array}$} & \multicolumn{2}{|c|}{ Absorption } \\
\hline & & $\begin{array}{c}\text { Number } \\
\text { usịng }\end{array}$ & $\begin{array}{l}\text { Percent } \\
\text { of total } \\
\text { respon- } \\
\text { dents }\end{array}$ & $\begin{array}{l}\text { Number } \\
\text { using }\end{array}$ & $\begin{array}{l}\text { Percent } \\
\text { of total } \\
\text { respon- } \\
\text { dents }\end{array}$ & $\begin{array}{l}\text { Number* } \\
\text { ușing }\end{array}$ & $\begin{array}{l}\text { Percent } \\
\text { of total } \\
\text { respon- } \\
\text { dents }\end{array}$ \\
\hline Medical & 6 & 0 & 0.0 & 4 & 23.5 & 2 & 11.8 \\
\hline Educational & 4 & 1 & 5.9 & 3 & 17.6 & 1 & 5.9 \\
\hline Industrial & 5 & 0 & 0.0 & 3 & 17.6 & 5 & 29.4 \\
\hline Power Reactor & 0 & - & - & - & - & - & \\
\hline Governmental & 2 & 1 & 5.9 & 1 & 5.9 & 1 & 5.9 \\
\hline TOTAL & 17 & 2 & 11.8 & 11 & 64.7 & 9 & 52.9 \\
\hline
\end{tabular}

*The total of "number using" exceeds the total number of respondents due to the use of several practices at each facility. 
TABLE 6-9

SHIPPING CONTAINER USSED

\begin{tabular}{|c|c|c|c|c|c|c|c|}
\hline \multirow[b]{2}{*}{$\begin{array}{c}\text { Type } \\
\text { of Facility }\end{array}$} & \multirow[b]{2}{*}{$\begin{array}{l}\text { Number } \\
\text { of } \\
\text { respon- } \\
\text { dents }\end{array}$} & \multicolumn{2}{|c|}{ 55-gal. drums } & \multicolumn{2}{|c|}{ 30-gal. drums } & \multicolumn{2}{|c|}{ Others } \\
\hline & & $\begin{array}{c}\text { Number } \\
\text { using }\end{array}$ & $\begin{array}{l}\text { Percent } \\
\text { of total } \\
\text { respon- } \\
\text { dents }\end{array}$ & $\begin{array}{l}\text { Number* } \\
\text { ussing }\end{array}$ & $\begin{array}{l}\text { Percent } \\
\text { of total } \\
\text { respon- } \\
\text { dents }\end{array}$ & $\begin{array}{l}\text { Number * } \\
\text { using }\end{array}$ & $\begin{array}{l}\text { Percent } \\
\text { of total } \\
\text { respon- } \\
\text { dents }\end{array}$ \\
\hline Medical & 5 & 4 & 22.2 & 0 & 0.0 & 4 & 22,2 \\
\hline Educational & 5 & 4 & 22.2 & 0 & 0,0 & 1 & 5.6 \\
\hline Industrial & 7 & 7 & 38.9 & 2 & . 11.1 & 3 & 16.7 \\
\hline Power Reactor & 0 & - & - & - & - & - & - \\
\hline Governmental & 1 & 0 & 0.0 & 0 & 0.0 & 1. & 5.6 \\
\hline TOTAL & 18 & 15 & 83.3 & 2 & 11.1 & 9 & 50.0 \\
\hline
\end{tabular}

*The total of "number using" exceeds the total number of respondents due to several types of containers being used at some facilities. 
TABLE' $6-10$

PHYSICAL FORM OF SHIPPED WASTE

\begin{tabular}{|c|c|c|c|c|c|c|c|c|c|c|c|}
\hline \multirow[b]{2}{*}{$\begin{array}{c}\text { Type } \\
\text { of facility }\end{array}$} & \multirow[b]{2}{*}{$\begin{array}{l}\text { Number of } \\
\text { respondents }\end{array}$} & \multicolumn{2}{|c|}{ Dry } & \multicolumn{2}{|c|}{$\begin{array}{l}\text { Moist/potential } \\
\text { free liquid }\end{array}$} & \multicolumn{2}{|c|}{ Biological waste } & \multicolumn{2}{|c|}{ Sealed sources } & \multicolumn{2}{|c|}{ Other } \\
\hline & & $\begin{array}{l}\text { Number of } \\
\text { facilities }\end{array}$ & $\begin{array}{c}\text { Percent } \\
\text { of total } \\
\text { respon- } \\
\text { dents }\end{array}$ & $\begin{array}{l}\text { Number of } \\
\text { facilities }\end{array}$ & $\begin{array}{l}\text { Percent } \\
\text { of total } \\
\text { respon- } \\
\text { dents }\end{array}$ & $\begin{array}{l}\text { Number of } \\
\text { facilities }\end{array}$ & $\begin{array}{c}\text { Percent } \\
\text { of total } \\
\text { respon- } \\
\text { dents }\end{array}$ & $\begin{array}{l}\text { Number of } \\
\text { facilities }\end{array}$ & $\begin{array}{c}\text { Percent } \\
\text { of total } \\
\text { respon- } \\
\text { dents }\end{array}$ & $\begin{array}{c}\text { Number of } \\
\text { facilities }\end{array}$ & $\begin{array}{l}\text { Percent } \\
\text { of total } \\
\text { respon- } \\
\text { dents }\end{array}$ \\
\hline Medical & 6 & 3 & 15.8 & 5 & $26.3^{\circ}$ & 2 & 10.5 & o & 0.0 & 2 & 10.5 \\
\hline Educational & 5 & 3 & 15.8 & 3 & 15.8 & 3 & 15.8 & 1 & 5.3 & 1 & 5.3 \\
\hline Industrial & 6 & 4 & 21.1 & 4 & 21.1 & 1 & 5.3 & 1 & 5.3 & 1 & 5.3 \\
\hline Power Reactor & 0 & - & - & - & - & - & - & - & - & - & - \\
\hline Governmental & 2 & 1 & 5.3 & 1 & .5 .3 & 0 & .0 .0 & .0 & 0.0 & 0 & 0.0 \\
\hline TOTAL & .19 & 11 & 57.9 & 13 & 68.4 & .6 & 31.6 & 2 & 10.5 & 4 & 21.1 \\
\hline
\end{tabular}

*The total of "number of facilities" exceeds the total number of respondents due to waste being in several forms at some facilities. 
APPENDIX A

RADIOACTIVE MATERIAL LICENSEES

IN THE STATE OF WASHINGTON

$\because$

A-1 
Column 1:

Column 2:

Column 3:

Column 4:

Column 5:
Name and address as provided by the Washington Radioactive Materials Control Unit

$\mathrm{N}$ indicates questionnaire was not delivered as evidenced by package being returned by postal service

$Y$ indicates questionnaire was mailed and not returned by the postal service

$\mathrm{N}$ indicates that no response to the written questionnaire was received

I indicates the 1 icensee did respond and provided all approprịate information

2 indicates the licensee did respond but provided only information on type of facility, disposal method, and quantity of waste

3 indicates the licensee did respond but provided only information on type of facility and disposal method

$M=$ Medical

$E=$ Educational

$I=$ Inductrial

$\mathrm{P}=$ Power Reactor

$\dot{G}=$ Goverrimental

$\mathrm{U}=$ Unknown

$Y$ indicates the licensee ships wastes to a commercial disposal site

$\mathrm{N}$ indicates the 1 icensee does not ship wastes

- indicates information not available 


\begin{tabular}{|c|c|c|c|c|c|}
\hline \multirow{2}{*}{ Liconseo Name and Address } & \multicolumn{2}{|c|}{ Questionnaire } & \multirow{2}{*}{ 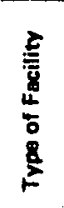 } & \multirow[b]{2}{*}{ 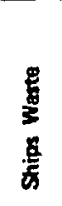 } & \multirow{2}{*}{ Comments } \\
\hline & $\frac{8}{\overline{8}}$ & $\frac{8}{8}$ & & & \\
\hline $\begin{array}{l}\text { ABAM Engineers, Inc. } \\
\text { Attn: Donald C. Casad } \\
1127 \text { Port of Tacoma Road } \\
\text { Tacoma, } \Psi \text { A } 98421\end{array}$ & $Y$ & 2 & I & $\dot{\mathrm{N}}$ & \\
\hline $\begin{array}{l}\text { Max J. Allen, M. D. } \\
230 \text { Medical Center Building } \\
\text { Spokane, WA } 98202\end{array}$ & Y & 2 & $M$ & $N$ & \\
\hline $\begin{array}{l}\text { Allenmore Community Hospital } \\
\text { Attn: - Kenneth E. Gross, M.D } \\
\text { S. 19th and Union } \\
\text { Tacoma, WA } 98405\end{array}$ & $\mathbf{Y}$ & 2 & $M$ & $\mathbf{N}$ & . \\
\hline $\begin{array}{l}\text { Altinay and Associates, Inc. } \\
\text { Attn: Mr. S. S. Altinay } \\
5241 \text { South Graham } \\
\text { Soattlo, WA } 98118 \\
\end{array}$ & $\mathrm{Y}$ & 2 & I & $\mathbf{N}$ & No waste. Consultants. \\
\hline $\begin{array}{l}\text { AMFAC Foods } \\
\text { Attn: W. R. Huaber } \\
\text { West Industrial Tract } \\
\text { Quincy, WA } 98848 \\
\end{array}$ & $Y$ & N & 1 & - & . \\
\hline $\begin{array}{l}\text { Am Test, Inc. } \\
\text { Attn: Arthur D. Olsen } \\
1450-114 \text { th Avenue S.E., Suite } 120 \\
\text { Bellevue, WA } 98004\end{array}$ & $Y$ & 2 & 1 & $\mathbf{N}$ & Source in gauges. \\
\hline $\begin{array}{l}\text { Anvil Chemical \& Biological } \\
\text { Testing Lab. } \\
\text { Attn: George Griffith } \\
1675 \text { w. Bakerview Road } \\
\text { Bellinglam.WA g8225 }\end{array}$ & $Y$ & $\mathbf{N}$ & I & - & \\
\hline $\begin{array}{l}\text { Anvil Chemir a! Blological } \\
\text { Testing Lab. } \\
\text { Attn: Wallace L. Rankin } \\
\text { I675 W. Bakerview Road } \\
\text { Bellingham.WA 98225 }\end{array}$ & $Y$ & $N$ & 1 & - & \\
\hline $\begin{array}{l}\text { Wm. G. Applctun, J! , M.U } \\
355 \text { N.W. Beach Roar } \\
\text { Seattle, WA } 98177\end{array}$ & $y$ & 2 & $M$ & $N$ & . \\
\hline $\begin{array}{l}\text { Arvid Grant \& Assoc, inc. } \\
\text { Attn: W. Roger Johnson } \\
702 \text { W. Lewis } \\
\text { Pasco, WA } 99301\end{array}$ & $N$ & - & 1 & - & . \\
\hline $\begin{array}{l}\text { Assoclated Sand \& Gravel } \\
\text { Attn: John Lilly } \\
6300 \text { Glenwood Avenue } \\
\text { Everelt, WA } 98203\end{array}$ & $Y$ & 2 & 1 & $\mathbf{N}$ & \\
\hline $\begin{array}{l}\text { Atlantic Richfield Company } \\
\text { Attn: W. R. Powell } \\
\text { P.O. Box } 1127 \\
\text { Cherry Point Refinary } \\
\text { Ferndale, WA 98248 } \\
\end{array}$ & $Y$ & $N$ & 1 & - & \\
\hline $\begin{array}{l}\text { Atlas Foundry and Machine Co. } \\
\text { Attn: Warren Engle } \\
\text { 3021 S. Wikeson Street } \\
\text { Tacoma, WA } 98411\end{array}$ & $\mathbf{Y}$ & 2 & 1 & $\mathrm{~N}$ & \\
\hline $\begin{array}{l}\text { Auburn General Hnspital } \\
\text { Attn: Michael J. Spiger, M.D. } \\
\text { 20 Second St., N.E. } \\
\text { Auburn, WA } 98002\end{array}$ & $Y$ & 2 & $M$ & $N$ & . \\
\hline
\end{tabular}




\begin{tabular}{|c|c|c|c|c|c|c|}
\hline \multirow[b]{2}{*}{ Licenseo Name and Addreas } & \multirow[b]{2}{*}{. } & \multicolumn{2}{|c|}{ Questionnaire } & \multirow{2}{*}{ 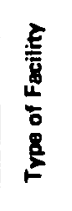 } & \multirow[b]{2}{*}{$\begin{array}{l}\frac{8}{6} \\
\frac{6}{5} \\
\frac{6}{6}\end{array}$} & \multirow[b]{2}{*}{ Comments } \\
\hline & & $\frac{8}{8}$ & 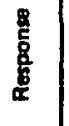 & & & \\
\hline $\begin{array}{l}\text { John D. Bagdade, M.D. } \\
\text { Providence Hospital } \\
500 \text { 17th Ave., Rm } 664 \\
\text { Seattle, WA } 98122\end{array}$ & & $\dot{y}$ & 3 & $M$ & $\mathbf{Y}$ & $\begin{array}{l}\text { Waste collected through } \\
\text { University of Washington. }\end{array}$ \\
\hline $\begin{array}{l}\text { John L. Bakke, M,D. } \\
910 \text { Boylston } \\
\text { Seattle, WA } 98104\end{array}$ & & $Y$ & 2 & $M$ & $N$ & . \\
\hline $\begin{array}{l}\text { Ballard Community Hospital } \\
\text { Attn: George J. Stead, M.D } \\
5409 \text { Barnes Ave., N.W. } \\
\text { Seattle. WA } 98107\end{array}$ & . & $Y$ & $N$ & M & - & . \\
\hline $\begin{array}{l}\text { Ralph Baltzo } \\
3841 \text { N.E. 87th Street } \\
\text { Seattle, WA } 98115\end{array}$ & & $Y$ & 2 & I & $Y$ & Waste broker. \\
\hline $\begin{array}{l}\text { L. H. Bates Voc-Technical } \\
\text { Attn: B. L. Rrainard } \\
\text { 110I South Yakima Avenue } \\
\text { Tacoma, WA } 98405\end{array}$ & & Y & 2 & $E$ & $N$ & $\cdot$ \\
\hline $\begin{array}{l}\text { Battelle Pacific N.W. Laboratories } \\
\text { Attn: T. W. Ambrose, Director } \\
\text { Sequim Research Lab., } \\
\text { Rt. S, Box } 10000 \\
\text { Sequim WA } 98382 \\
\end{array}$ & & $Y$ & 1 & 1 & $Y$ & . \\
\hline $\begin{array}{l}\text { Bellevue Radiology Consultants, Inc. } \\
\text { Attn: Harry A. Grant, M.D. } \\
1201 \text { 16th Avenue East } \\
\text { Bellevue, WA } 98004\end{array}$ & . & $Y$ & $\mathbf{N}$ & M & - & \\
\hline $\begin{array}{l}\text { Bellevue-Redmond Medical Lab } \\
\text { Attn: Raymon Suen, M.D, } \\
\text { 15690 N.E. 21st Street } \\
\text { Bellevue, WA y8uus }\end{array}$ & & $Y$ & 1 & $\mathbf{M}$ & $N$ & \\
\hline $\begin{array}{l}\text { Bendix-Skagit Corporation } \\
\text { Attn: Herb Reichert } \\
500 \text { Metcalf Street } \\
\text { Sedro Woolley, WA } 98284\end{array}$ & & $Y$ & 1 & 1 & $N$ & \\
\hline $\begin{array}{l}\text { Benton County Engineer } \\
\text { Attn: Dale E. Bean, County Engineer } \\
\text { Courthouse Annex } \\
\text { Prusste, WA } 99350\end{array}$ & . & $Y$ & $N$ & G & - & 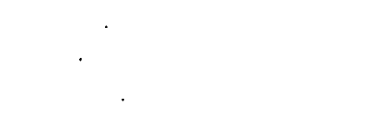 \\
\hline $\begin{array}{l}\text { B.G.C., Inc. } \\
5709-80 \text { th N.E. } \\
\text { Mercer Is., WA } 9.6040\end{array}$ & & 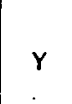 & $N$ & 1 & - & ' \\
\hline $\begin{array}{l}\text { Birchfield, Inc. } \\
\text { Attn: Soren R. Johanson } \\
1515 \text { I28th Place N.E } \\
\text { Bellevue, WA } 98009\end{array}$ & & $Y$ & $\mathbf{N}$ & 1 & - & \\
\hline $\begin{array}{l}\text { Skagit Valley Laboratories } \\
\text { Attn: Ian Black, M.D. } \\
1310 \text { East Divigion Stroot } \\
\text { Mt. Vernon, WA } 98273\end{array}$ & & $Y$ & 1 & 1 & $\mathbf{N}$ & \\
\hline $\begin{array}{l}\text { The Boeing Company } \\
\text { Attn: W, E. Morgan } \\
\text { Chief-Radiation Health Protection } \\
\text { P.O. Box } 3707 \\
\text { Seattle, WA } 98124\end{array}$ & & $Y$ & 1 & 1 & $Y$ & \\
\hline
\end{tabular}




\begin{tabular}{|c|c|c|c|c|c|}
\hline \multirow[b]{2}{*}{ Licensee Name and Address } & & Questionnaire & \multirow{2}{*}{ 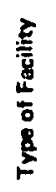 } & \multirow[b]{2}{*}{$\begin{array}{l}\frac{9}{6} \\
\frac{5}{5} \\
\frac{5}{5}\end{array}$} & \multirow[b]{2}{*}{ Comments } \\
\hline & $\frac{5}{5}$ & $\frac{8}{8}$ & & & \\
\hline $\begin{array}{l}\text { Boise-Cascade Corporation } \\
\text { Attn: Donald Robinson } \\
\text { Chambers Creek Road, P.O. Box W } \\
\text { Steilacoom, WA } 98358\end{array}$ & . & $\mathbf{N}$ & 1 & - & . \\
\hline $\begin{array}{l}\text { Boise-Cascade Papers } \\
\text { Attn: Ernest G Paradis } \\
\text { P.O. Box } 500 \\
\text { Wallula, WA } 99363\end{array}$ & $\mathbf{Y}$ & 2 & ! & $N$ & \\
\hline $\begin{array}{l}\text { Bovay Engineers } \\
808 \text { East Sprague Avenue } \\
\text { Spokane, WA } 99202\end{array}$ & $\gamma$ & $\begin{array}{l}\mathbf{N} \\
\ddots\end{array}$ & 1 & - & \\
\hline $\begin{array}{l}\text { Budinger Geotechnical Engineering } \\
408 \text { N. Pines Road } \\
\text { Spokane, WA } 99206\end{array}$ & $Y$ & 2 & 1 & N & $\cdot$ \\
\hline $\begin{array}{l}\text { Builders Concrete, Inc. } \\
\text { Attn: Wesley Sluys } \\
C \text { and Maple Streets } \\
\text { Bellingham, WA } 98225\end{array}$ & $\mathbf{Y}$ & 2 & I & $\mathbf{N}$ & . \\
\hline $\begin{array}{l}\text { Burien Medical Lab. } \\
\text { I } 50018 \text { th Avenue S.W. } \\
\text { Seattle, WA } 98166\end{array}$ & $\mathbf{Y}$ & 1 & $\mathbf{M}$ & $\mathbf{Y}$ & $\begin{array}{l}\text { Since } 1978 \text { waste disposed via } \\
\text { Ralph Baltzo. }\end{array}$ \\
\hline $\begin{array}{l}\text { Cam Industries } \\
\text { Attn: R. Clay Meyers } \\
1825068 \text { th Avenue South } \\
\text { Kent, WA } 98031\end{array}$ & $Y$ & $N$ & 1 & - & \\
\hline $\begin{array}{l}\text { Canadian Arctic Survey Systems } \\
\text { Attn: George S. Samchuck } \\
108 \text { S. Tower Avenue, Box } 388 \\
\text { Centralia, WA } 98531\end{array}$ & $Y$ & $\mathbf{N}$ & 1 & - & \\
\hline $\begin{array}{l}\text { Çarborundum rompany } \\
\text { Attn: William Leiner } \\
\text { 2ssu N.W. Lower River Road, } \\
\text { P O. Box } 291 \\
\text { Yancouver. WA } 98660\end{array}$ & $y$ & 2 & 1 & iv & No wiasle. \\
\hline $\begin{array}{l}\text { Carnation Company } \\
\text { Processed Potato Div. } \\
\text { P.O. Box } 587 \\
\text { Oilleliv. WA yy } 344\end{array}$ & $Y$ & 2 & 1 & $\mathbf{N}$ & Sources in gauges. \\
\hline $\begin{array}{l}\text { Carnation Company } \\
\text { Attn: John H. Walsh } \\
\text { R.1. 2, Box 60C } \\
\text { Moses Lake, WA } 98837\end{array}$ & $\mathbf{Y}$ & 2 & 1 & $N$ & No waste. \\
\hline $\begin{array}{l}\text { Cascade Testing Lab., Inc. } \\
14120 \text { N.E. } 21 \text { st Street } \\
\text { Bellevue, WA } 98007\end{array}$ & $\mathbf{Y}$ & 2 & 1 & $\mathbf{N}$ & No waste. . \\
\hline $\begin{array}{l}\text { Central Washington State College } \\
\text { Attn: Bernard L. Martin } \\
\text { School of Natura! Science/Mathematics } \\
\text { Ellensburg, WA } 98926\end{array}$ & $\mathbf{Y}$ & 3 & $\mathbf{E}$ & $\mathrm{Y}$ & \\
\hline $\begin{array}{l}\text { Chef-Reddy Fooda Corporation } \\
\text { North Broadway and Lee Roads } \\
\text { P.O. Box } 607 \\
\text { Othello, WA } 99344\end{array}$ & Y. & 2 & 1 & $\mathbf{N}$ & Sources in gauges. \\
\hline
\end{tabular}




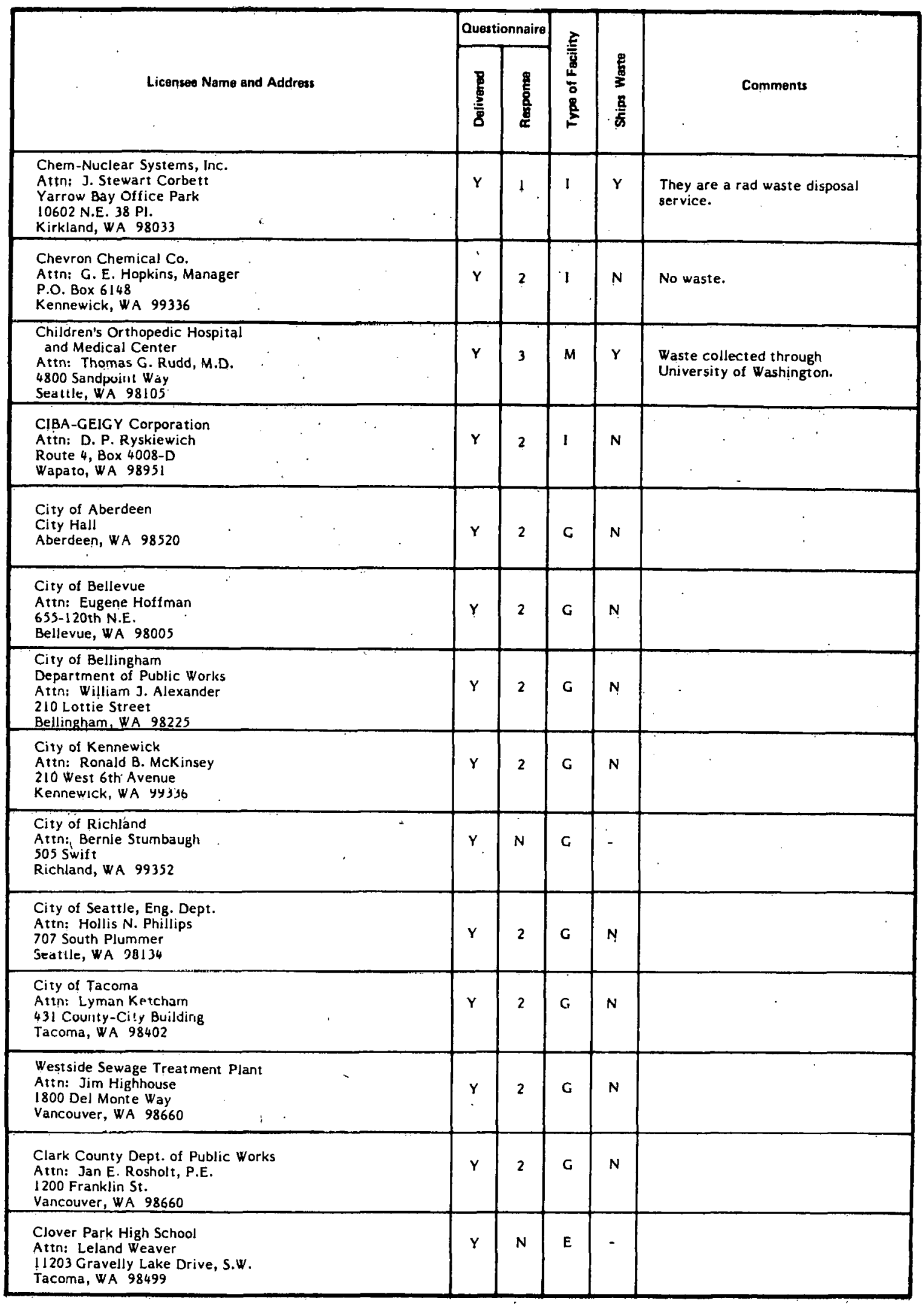




\begin{tabular}{|c|c|c|c|c|c|c|}
\hline \multirow[b]{2}{*}{ Licenseo Namo and Address } & \multicolumn{2}{|c|}{ Questionnaire } & \multirow{2}{*}{ 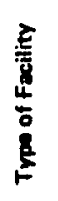 } & \multirow{2}{*}{$\begin{array}{l}\frac{9}{0} \\
\frac{1}{3} \\
\frac{0}{5}\end{array}$} & \multirow{2}{*}{\multicolumn{2}{|c|}{ Comments }} \\
\hline & $\frac{8}{8}$ & $\frac{8}{8}$ & & & & \\
\hline $\begin{array}{l}\text { Columbia Radiation Therapy Clinic } \\
\text { Attn: Korth E. Bingham, M.D. } \\
203 \text { w. 8th Street } \\
\text { Kennewick, WA } 99336\end{array}$ & $\mathbf{Y}$ & 2 & $M$ & $\mathbf{N}$ & - & \\
\hline $\begin{array}{l}\text { Columbia River Red Cross Blood Ctr. } \\
\text { Attn: Anthony P. Fappiano, M.D. } \\
311 \text { East D Street } \\
\text { Yakima, WA } 98907\end{array}$ & $\mathbf{Y}$ & 2 & M & $N$ & . & $\sigma$ \\
\hline $\begin{array}{l}\text { Columbia Testing, Inc. } \\
\text { Attn: Michael J. Shelly } \\
\text { Port of Moses Lake Bldg. } 2321 \\
\text { Moses Lake, WA } \$ 8837\end{array}$ & $\gamma$ & 2 & 1 & $N$ & No waste, consultants. & \\
\hline $\begin{array}{l}\text { Component Concepts, Inc. } \\
\text { Attn: Howard Mc:Mahan } \\
3229 \text { Pine Street } \\
\text { Everett, WA } 98201 \\
\end{array}$ & $Y$ & 3 & 1 & $\mathbf{N}$ & & \\
\hline $\begin{array}{l}\text { Converse, Davis and Assoc., Inc. } \\
\text { Attn: Eugene R. McMaster } \\
100 \text { West Harrison } \\
\text { Seattle, WA } 98199\end{array}$ & $\mathbf{Y}$ & $\mathbf{N}$ & 1 & - & & \\
\hline $\begin{array}{l}\text { Cornell, Howland, Hayes \& Merryfield } \\
777 \text { 106th Avenue N.E. } \\
\text { Bellevue, WA } 98004\end{array}$ & Y & $\mathbf{N}$ & I & - & & . \\
\hline $\begin{array}{l}\text { Cowlitz County Puhlic Works } \\
\text { Attn: James F. Thom } \\
305 \text { Church Street } \\
\text { Kelso, WA } 98626\end{array}$ & $Y$ & $N$ & G & - & & \\
\hline $\begin{array}{l}\text { Richard Croghan. M.D. } \\
803 \text { South ISth } \\
\text { Mt. Vernon, WA } 98273\end{array}$ & $Y$ & $\mathbf{N}$ & $M$ & - & & \\
\hline $\begin{array}{l}\text { Crown Zellerbach Corporation } \\
\text { Atri: J.U. Kendall } \\
\text { Pt. Angeles Mill-Ediz Hook } \\
\text { Pt. Angeles, WA } 98362\end{array}$ & $Y$ & $N$ & 1 & - & . & \\
\hline $\begin{array}{l}\text { Crown Zellerbach Corporation } \\
\text { Attn: Ronald E. Nowak } \\
\text { Port Townsend Mill } \\
\text { Pt. Townsend, WA } 98368 \\
\end{array}$ & $Y$ & $\mathbf{N}$ & $\mathbf{I}$ & - & - & \\
\hline $\begin{array}{l}\text { Crown Zellerbac'. Corporation } \\
\text { Central Research Division } \\
\text { Camias, WA } 98607\end{array}$ & $Y$ & 3 & $\mathbf{I}$ & $\mathbf{N}$ & & \\
\hline $\begin{array}{l}\text { Dames and Moore } \\
\text { Attn: K. H. Larson } \\
\text { Sulte joo Northgare texec. bldg̈. } \\
\text { Seattle, WA } 97125\end{array}$ & $Y$ & 3 & $!$ & $N$ & No waste, concultante. & \\
\hline $\begin{array}{l}\text { Dancontrol, Inc. } \\
\text { Attn: D. A. Danielson } \\
17 \text { N.W. Alder } \\
\text { lssaquah, WA } 98027\end{array}$ & $\mathbf{N}$ & $\cdot$ & 1 & $\cdot$ & . & \\
\hline $\begin{array}{l}\text { Davis-Sameh Laboratories, P.S. } \\
\text { Attn: Stephen C. Erfurth, Ph.D. } \\
120 \text { East Birch Street, Suite } 14 \\
\text { Walla Walla, WA } 99362\end{array}$ & $Y$ & $\mathbf{N}$ & $M$ & - & & \\
\hline
\end{tabular}




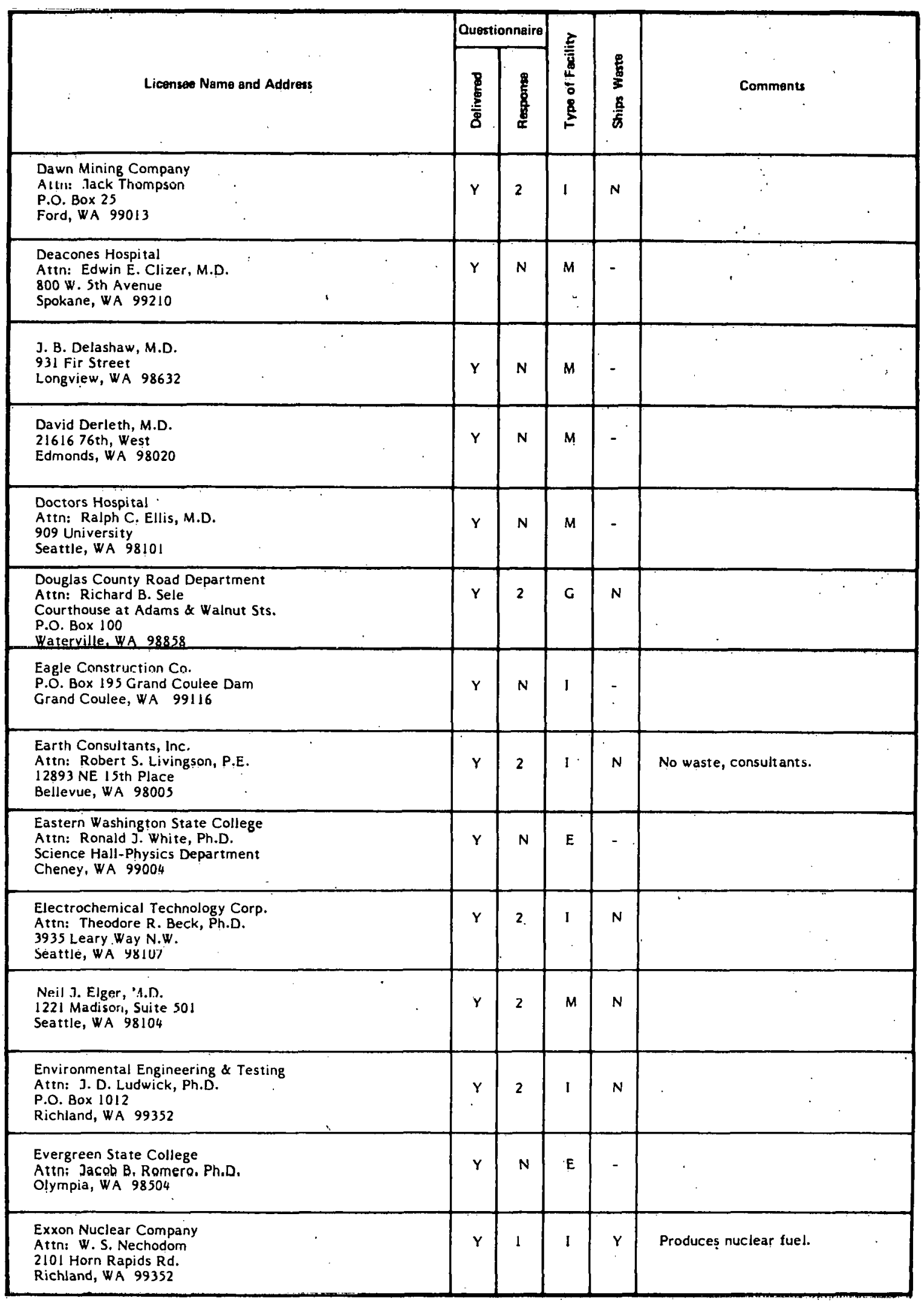




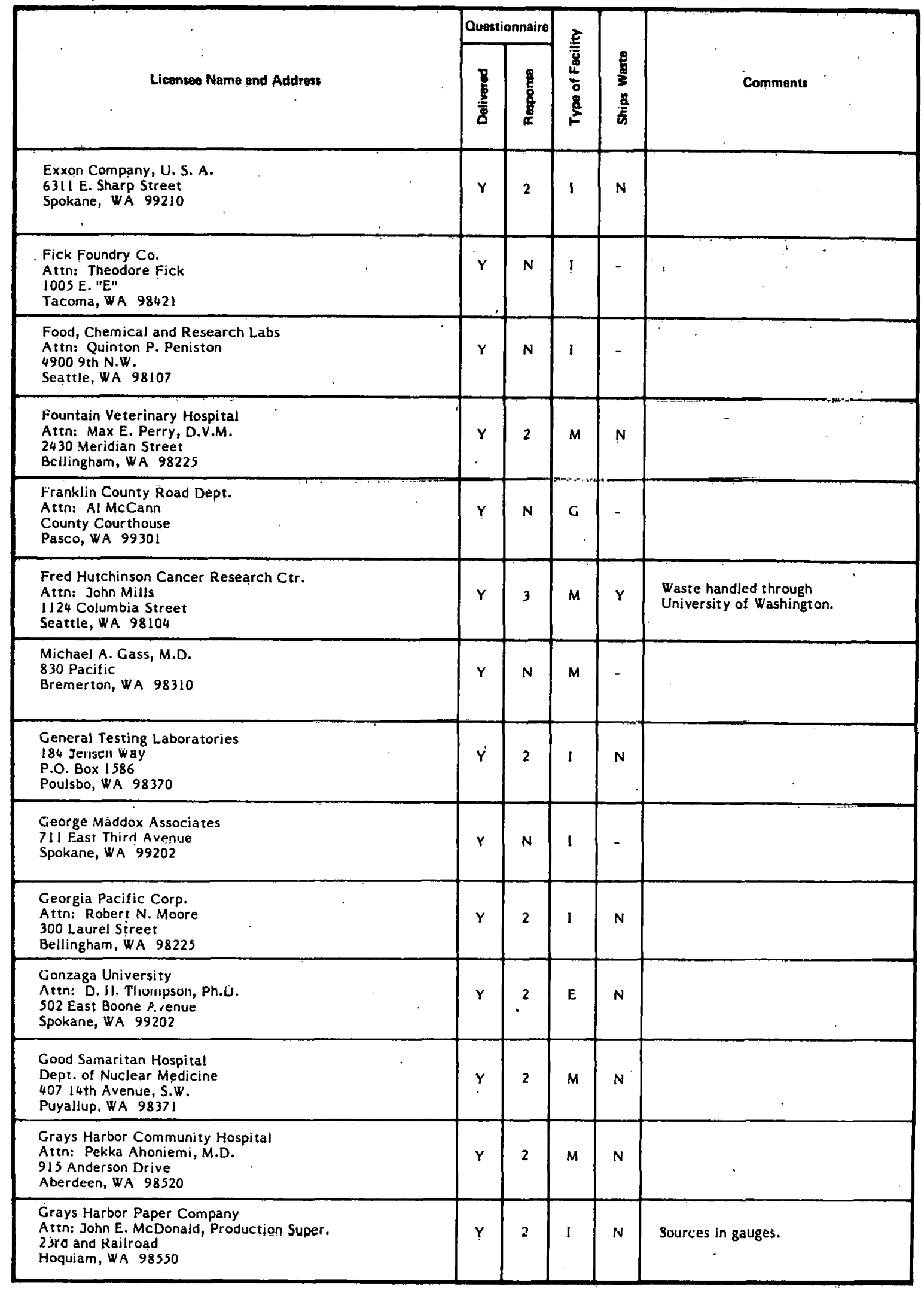




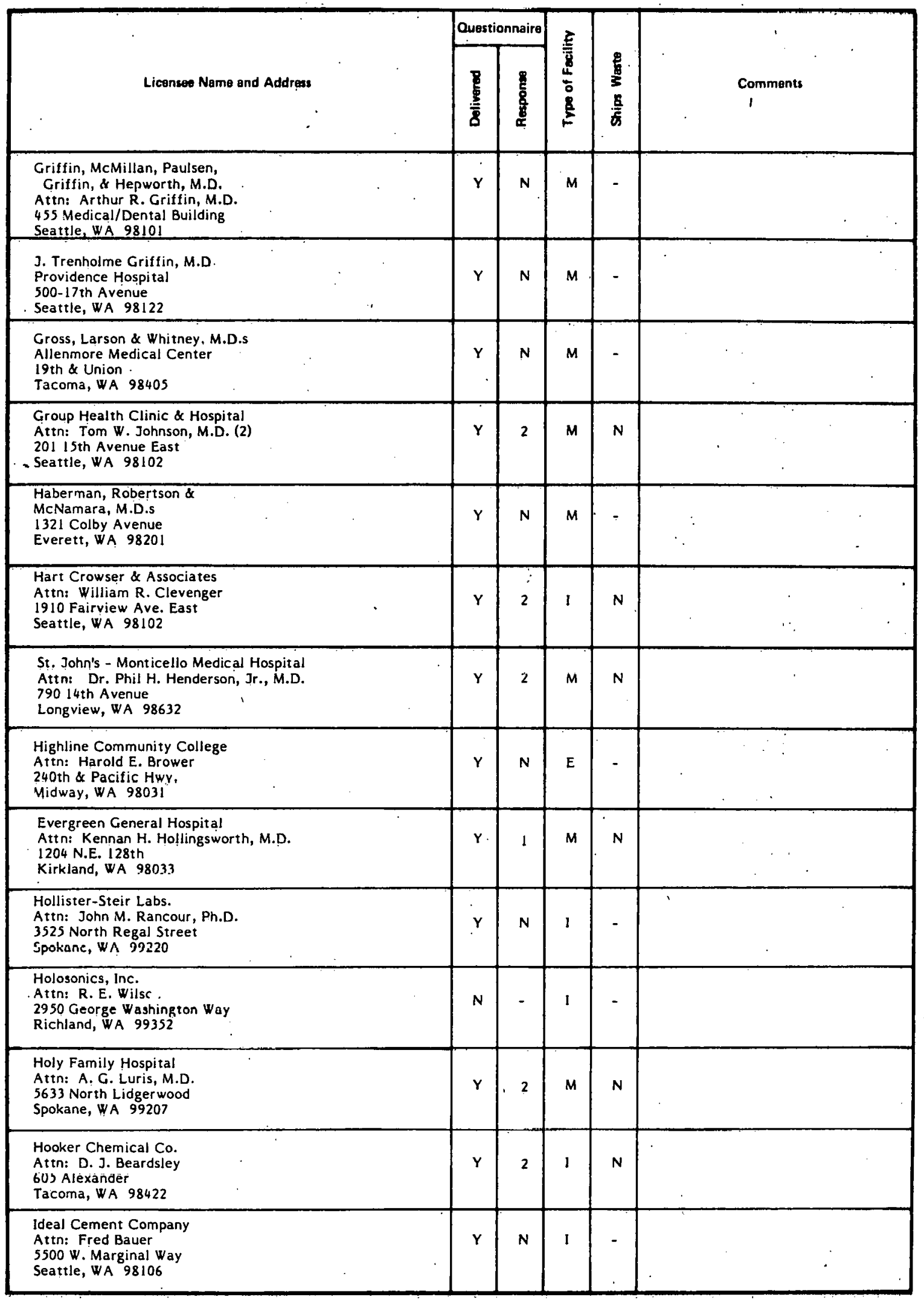




\begin{tabular}{|c|c|c|c|c|c|}
\hline \multirow[b]{2}{*}{ Licenses Name and Address } & \multicolumn{2}{|c|}{ Questionnaire } & \multirow{2}{*}{ 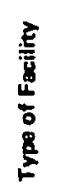 } & \multirow[b]{2}{*}{$\frac{5}{3}$} & \multirow[b]{2}{*}{ Comments } \\
\hline & $\frac{8}{8}$ & $\frac{8}{8}$ & & & \\
\hline $\begin{array}{l}\text { Inco United States, Inc. } \\
\text { Attn: Allen R. Foster } \\
300120 \text { th Ave., N.E., } \\
\text { Bldg. 7, Suite } 200 \\
\text { Bellevue, WA } 98005 \\
\end{array}$ & $Y$ & $\mathbf{N}$ & ! & - & . \\
\hline $\begin{array}{l}\text { Interstate Industrial Laundry } \\
\text { Attn: Waldo Garcia } \\
\text { 1100 Perry Avenue } \\
\text { Bremerton, WA } 98310 \\
\end{array}$ & $\dot{Y}$ & $\mathbf{N}$ & 1 & - & \\
\hline $\begin{array}{l}\text { Island Hospital } \\
\text { 24th and M Streets } \\
\text { Anacortes, WA } 98221\end{array}$ & $Y$ & 2 & $\dot{M}$ & $\mathbf{N}$ & \\
\hline $\begin{array}{l}\text { Issaquah Group for Health and } \\
\text { Environ. Research } \\
\text { Attn: Ruth Shearer, Ph.D. } \\
\text { I } 595 \text { N.W. Gillman } \\
\text { Issaguah WA } 28027\end{array}$ & $\mathbf{Y}$ & 1 & $\mathbf{M}$ & $\mathbf{Y}$ & Ships waste via Ra!ph Baltzo. \\
\hline $\begin{array}{l}\text { ITT-Rayonier, Inc. } \\
\text { Attn: D. C. Robertson } \\
\text { Pt. Angeles Division } \\
\text { Pt. Angeles, WA } 98362\end{array}$ & $\mathbf{Y}$ & 2 & 1 & $\mathbf{N}$ & \\
\hline $\begin{array}{l}\text { I.T.T. Rayonier, Inc. } \\
\text { Grays Harbor Division } \\
\text { Attn: Dan Gatch } \\
\text { 23rd \& Railroad } \\
\text { Hoquiam, WA } 98550 \\
\end{array}$ & $\mathbf{Y}$ & $N$ & 1 & - & $\cdot$ \\
\hline $\begin{array}{l}\text { ITT-Rayonier, Incorporated } \\
\text { Attn: Richard J. Engen, Ph.D. } \\
\text { Olympia Research Division } \\
\text { Shelton, WA } 98584\end{array}$ & $Y$ & 1 & 1 & $\mathbf{Y}$ & \\
\hline $\begin{array}{l}\text { A. Jones Gonstrutetion rin, } \\
\text { Attn: L. R. Thompson } \\
801 \text { First Street } \\
\text { Richland, WA } 99352\end{array}$ & $\mathbf{Y}$ & 2 & 1 & $\mathbf{N}$ & . \\
\hline $\begin{array}{l}\text { Joint Center For Graduate Studies } \\
\text { Attn: Peter K. Shen, Ph.D. } \\
100 \text { Sprout Road } \\
\text { Richland, WA } 99352\end{array}$ & $\mathbf{Y}$ & 1 & $E$ & $\mathbf{Y}$ & \\
\hline $\begin{array}{l}\text { Kadlec Hospital } \\
\text { Attn: Thomas D. Mahony M.D. } \\
888 \text { Swift Boulevard } \\
\text { Richland, WA } 99352\end{array}$ & $Y$ & $\mathbf{N}$ & $\mathbf{M}$ & - & \\
\hline $\begin{array}{l}\text { Kaiser Aluminum and Chemical Corp. } \\
\text { Attn: Floyd Sode-strom } \\
\text { Trenton Works } \\
\text { Spokanc, WA } 92207\end{array}$ & $Y$ & $\mathbf{N}$ & 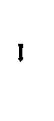 & - & · \\
\hline $\begin{array}{l}\text { Robert A. Kallsen, M.D. } \\
\text { "19L, South } \\
\text { Tacoma, WA } 98405\end{array}$ & $Y$ & $\mathbf{N}$ & $\mathbf{M}$ & - & \\
\hline $\begin{array}{l}\text { King County Central Blood Bank } \\
\text {-Attn: Sherril J. Slichter, M.D. } \\
\text { Terry at Madison } \\
\text { Seattle, WA } 98104\end{array}$ & $\mathbf{Y}$ & $\mathbf{N}$ & $\mathbf{M}$ & - & \\
\hline $\begin{array}{l}\text { King County Dept, of Public Works } \\
\text { Soils and Materidls Lab } \\
\text { Attn: Larry D. Bishop, Materials Engineer } \\
7735 \text { Leary Way N.E. } \\
\text { Seattle, WA } 98104\end{array}$ & $\mathbf{N}$ & - & $G$ & - & \\
\hline
\end{tabular}




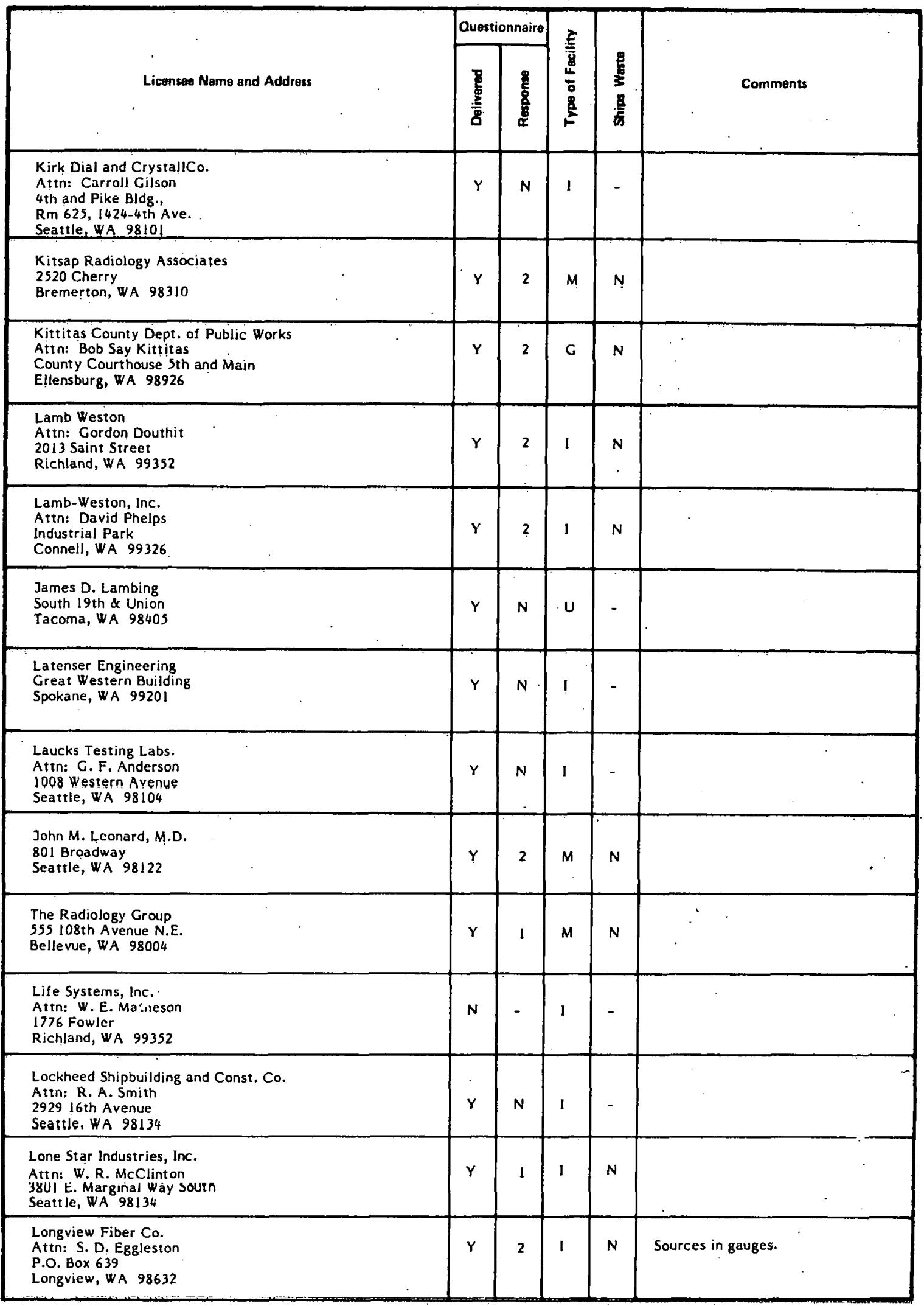




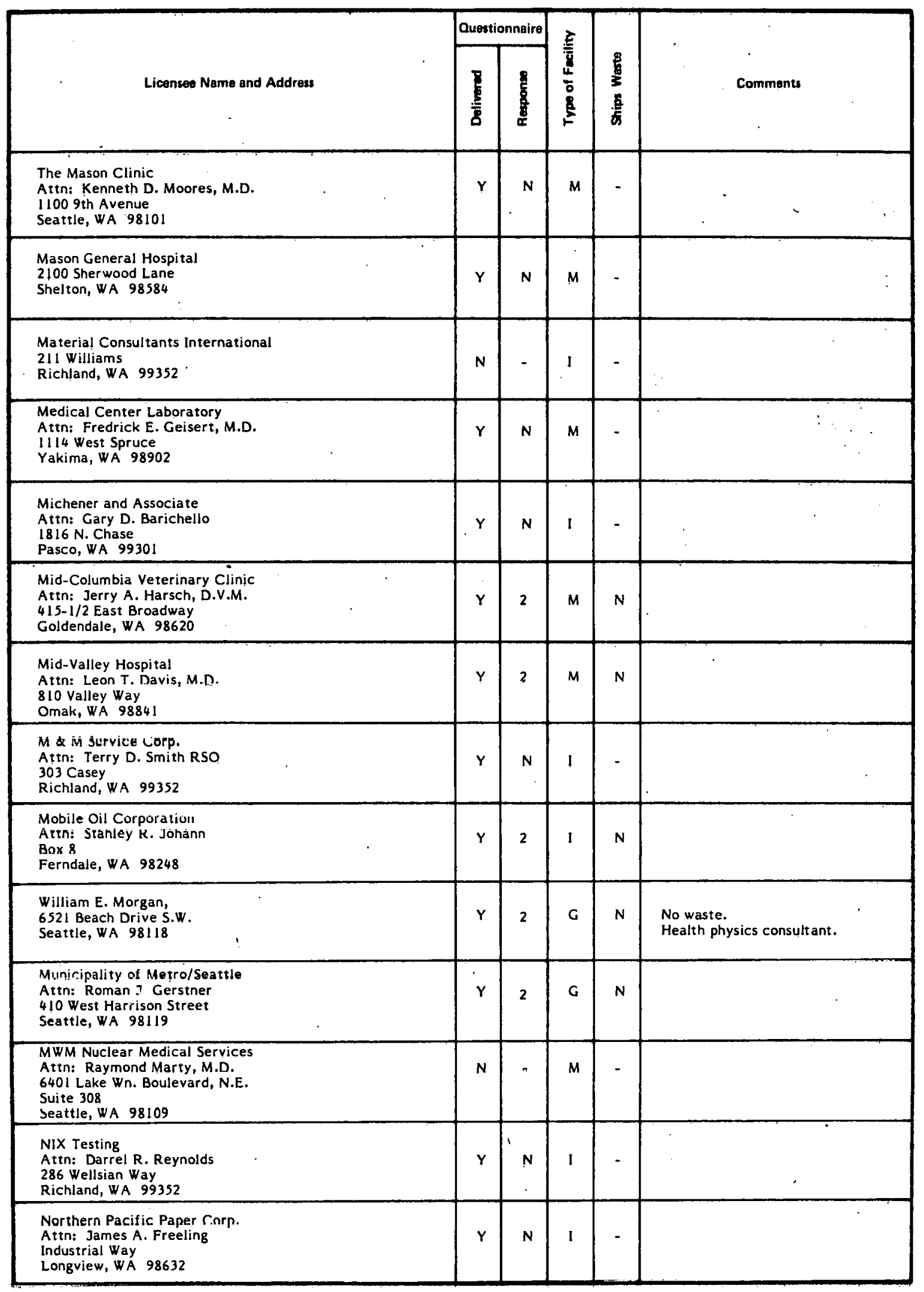




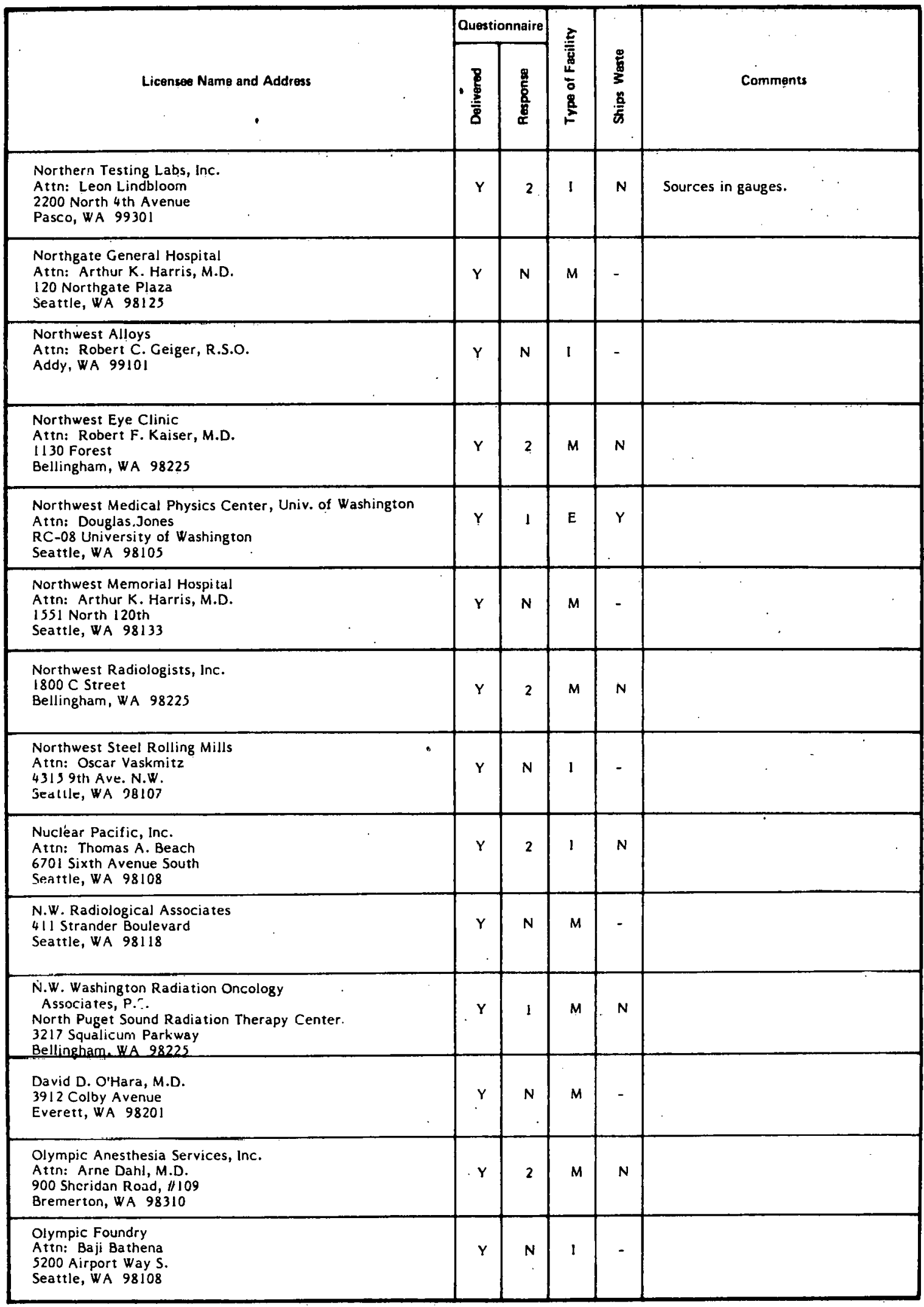




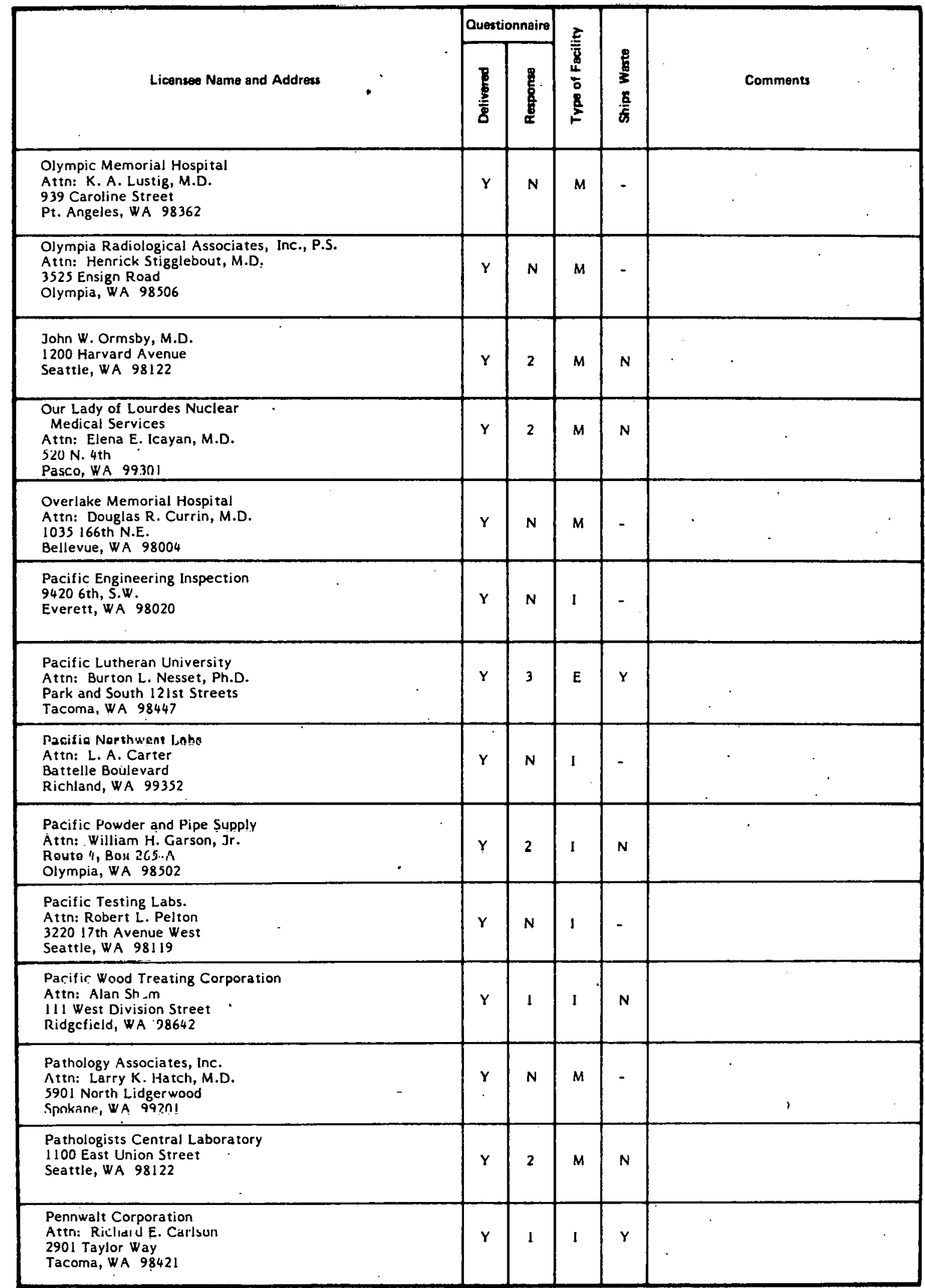




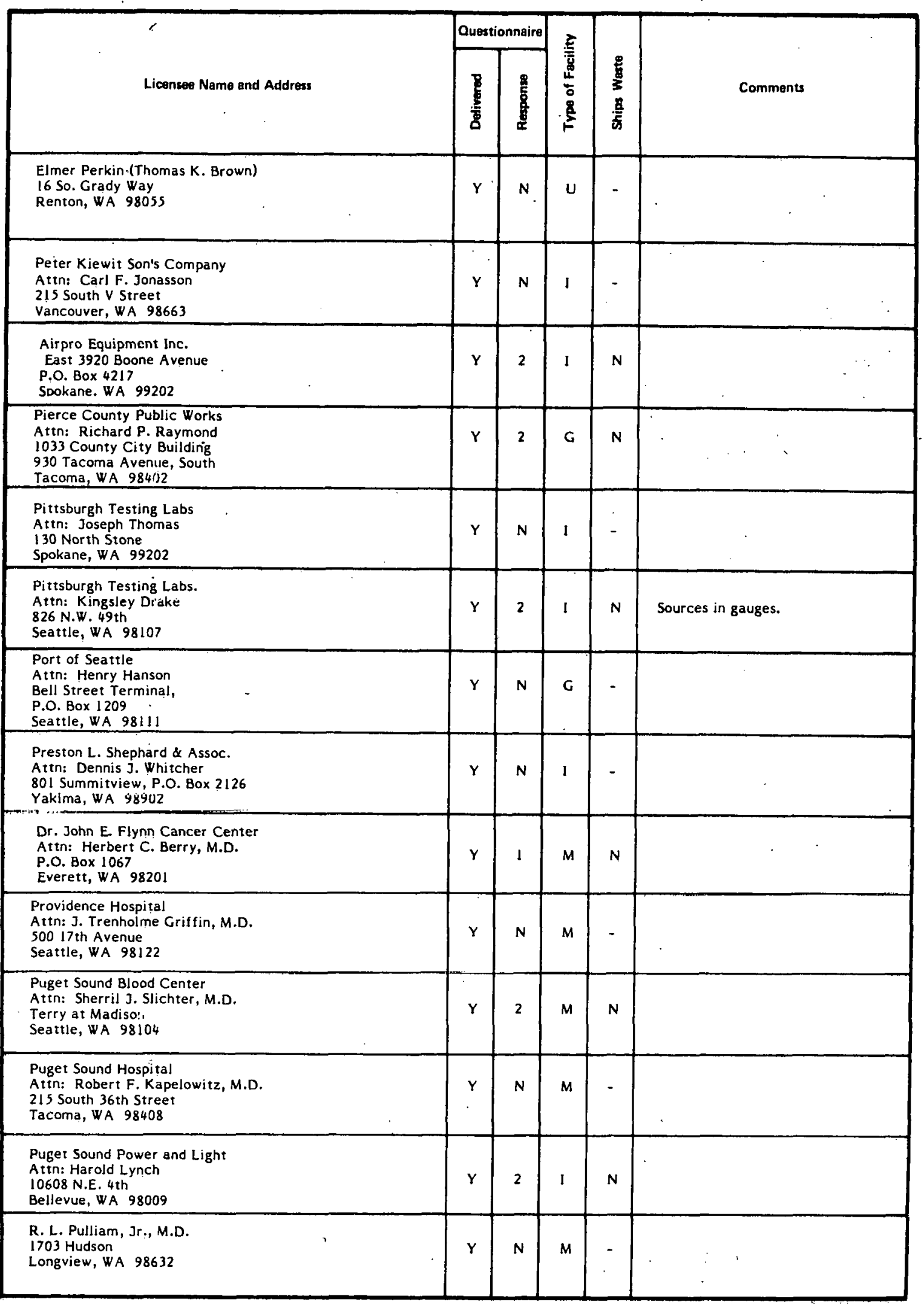




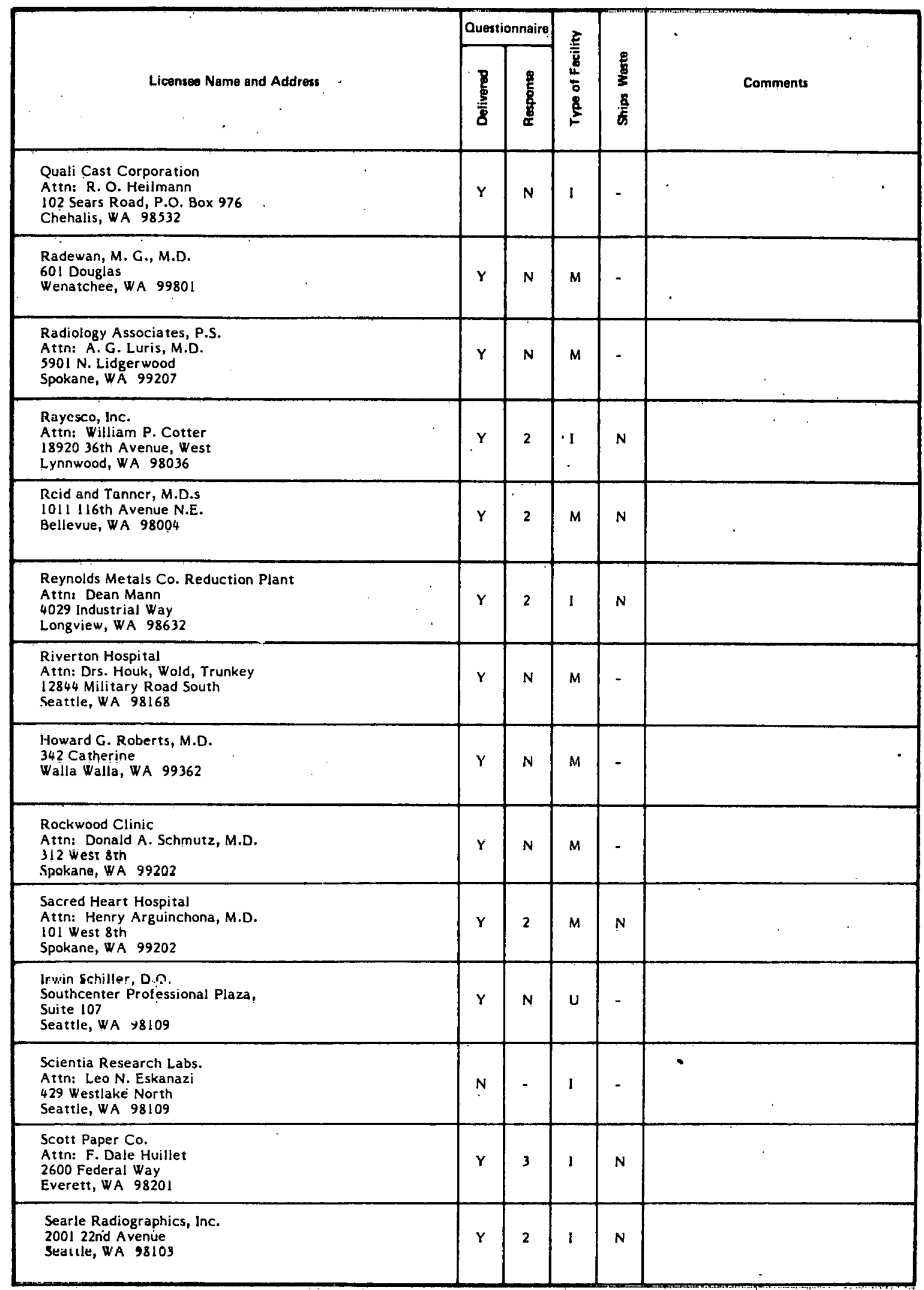




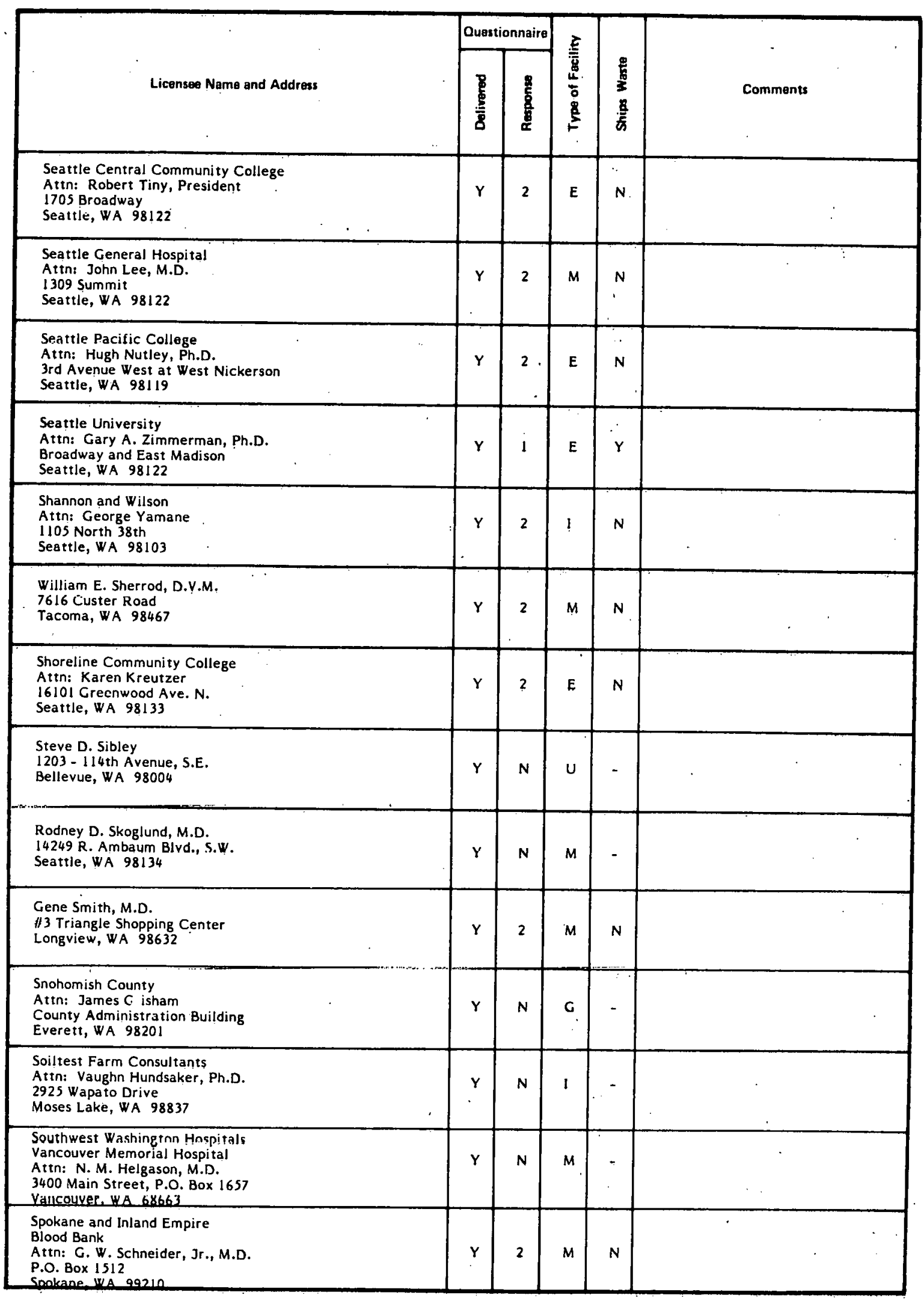




\begin{tabular}{|c|c|c|c|c|c|c|}
\hline \multirow{2}{*}{$\begin{array}{l}1 \\
\text { Licensee Name and Address }\end{array}$} & \multicolumn{2}{|c|}{ Questionnaire } & \multirow{2}{*}{ 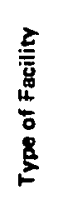 } & \multirow{2}{*}{$\begin{array}{l}\frac{8}{5} \\
\frac{5}{3} \\
\frac{\delta}{5}\end{array}$} & \multirow{2}{*}{\multicolumn{2}{|c|}{ Comments }} \\
\hline & $\frac{8}{\frac{8}{8}}$ & $\begin{array}{l}\frac{8}{6} \\
\frac{8}{6} \\
\frac{8}{6}\end{array}$ & & & & \\
\hline $\begin{array}{l}\text { Spokane County Engineering Dept. } \\
\text { Attn: Angelo Roman } \\
811 \text { North Jefferson } \\
\text { Spokane, WA } 99201\end{array}$ & $Y$ & 2 & G & $N$ & & \\
\hline $\begin{array}{l}\text { Spokane Falls Community College } \\
\text { Attn: W. T. Ardiss } \\
3410 \text { West Ft. George Wright Drive } \\
\text { Spokane, WA } 99201\end{array}$ & $Y$ & 2 & E & $N$ & & \\
\hline $\begin{array}{l}\text { Spokane Valley General Hospital } \\
\text { Attn: Joseph A. Tedesco, M.D. } \\
\text { 12606 East Mission Avenue } \\
\text { Spokane, WA } 99216\end{array}$ & $Y$ & $\mathbf{N}$ & $\mathbf{M}$ & - & . & \\
\hline $\begin{array}{l}\text { Square D. Company } \\
9840-40 \text { th Avenue South } \\
\text { Seattle, WA } 98124\end{array}$ & $Y$ & 2 & 1 & $N$ & $\cdot \quad:$ & \\
\hline $\begin{array}{l}\text { St. Elizabeth Hospital } \\
\text { Attn: Gayle F. Brewer, M.D. } \\
110 \text { South } 9 \text { th } \\
\text { Yakima, WA } 98901\end{array}$ & $Y$ & 2 & $M$ & $\mathbf{N}$ & $\cdot$ : & \\
\hline $\begin{array}{l}\text { St. Frances Xavier Cabrini Hospital } \\
\text { Attn: Gordon La Zerte, M.D. } \\
\text { Terry and Madison } \\
\text { Seattle, WA } 98104\end{array}$ & $Y$ & 3 & $M$ & $\mathrm{Y}$ & . & \\
\hline $\begin{array}{l}\text { St. John Hospital } \\
\text { Attn: William J. Elton, M.D. } \\
15 \text { th and Kessler } \\
\text { Longview, WA } 98632\end{array}$ & Y & 2 & $M$ & $N$ & . & $\cdot$ \\
\hline $\begin{array}{l}\text { St. Joseph Hospital } \\
\text { Attn: William B. Jackson, M.D. } \\
\text { 1718 South I } \\
\text { Tacoma, WA } 98401\end{array}$ & $Y$ & 2 & $M$ & $\mathbf{N}$ & . & \\
\hline $\begin{array}{l}\text { S1. Luke lluspilal } \\
\text { Attn: Peter J. Horn, M.D. } \\
711 \text { South Cowley Street } \\
\text { Spolionc, wa } 29210\end{array}$ & $Y$ & 2 & $M$ & $N$ & . & \\
\hline $\begin{array}{l}\text { St. Mary Community Hospital } \\
\text { Attn: Korth E. Bingham, M.D. } \\
\text { 401 W. Poplar } \\
\text { Walla Walla, WA } 99362\end{array}$ & $Y$ & $\mathbf{N}$ & $M$ & - & & \\
\hline $\begin{array}{l}\text { St. Mary Cornmunity Hospital } \\
\text { Attñ: Donäld M. Koser, M.D. } \\
401 \text { W. Poplar } \\
\text { Walla Walla, WA } 99362\end{array}$ & $Y$ & $N$ & $M$ & $\because$ & & \\
\hline $\begin{array}{l}\text { St. Mary Community Hospital } \\
\text { Attn: W. B. Howard, M.D. } \\
\text { 40I W. Poplar } \\
\text { Walla Walla, WA } 99362\end{array}$ & $\mathbf{Y}$ & $\mathbf{N}$ & $M$ & - & & \\
\hline $\begin{array}{l}\text { St. Peter Hospital } \\
\text { Attn: William J. Mikkelsen, M.D. } \\
413 \text { North Lilly Road } \\
\text { Olympia, WA } 98501\end{array}$ & $Y$ & $N$ & $M$ & - & & \\
\hline $\begin{array}{l}\text { St. Regis Paper Co. } \\
\text { Atth: H. R. Hack } \\
801 \text { Portland Avenue, North } \\
\text { Tacoma, WA } 98421\end{array}$ & $\gamma$ & $N$ & I & - & & \\
\hline
\end{tabular}




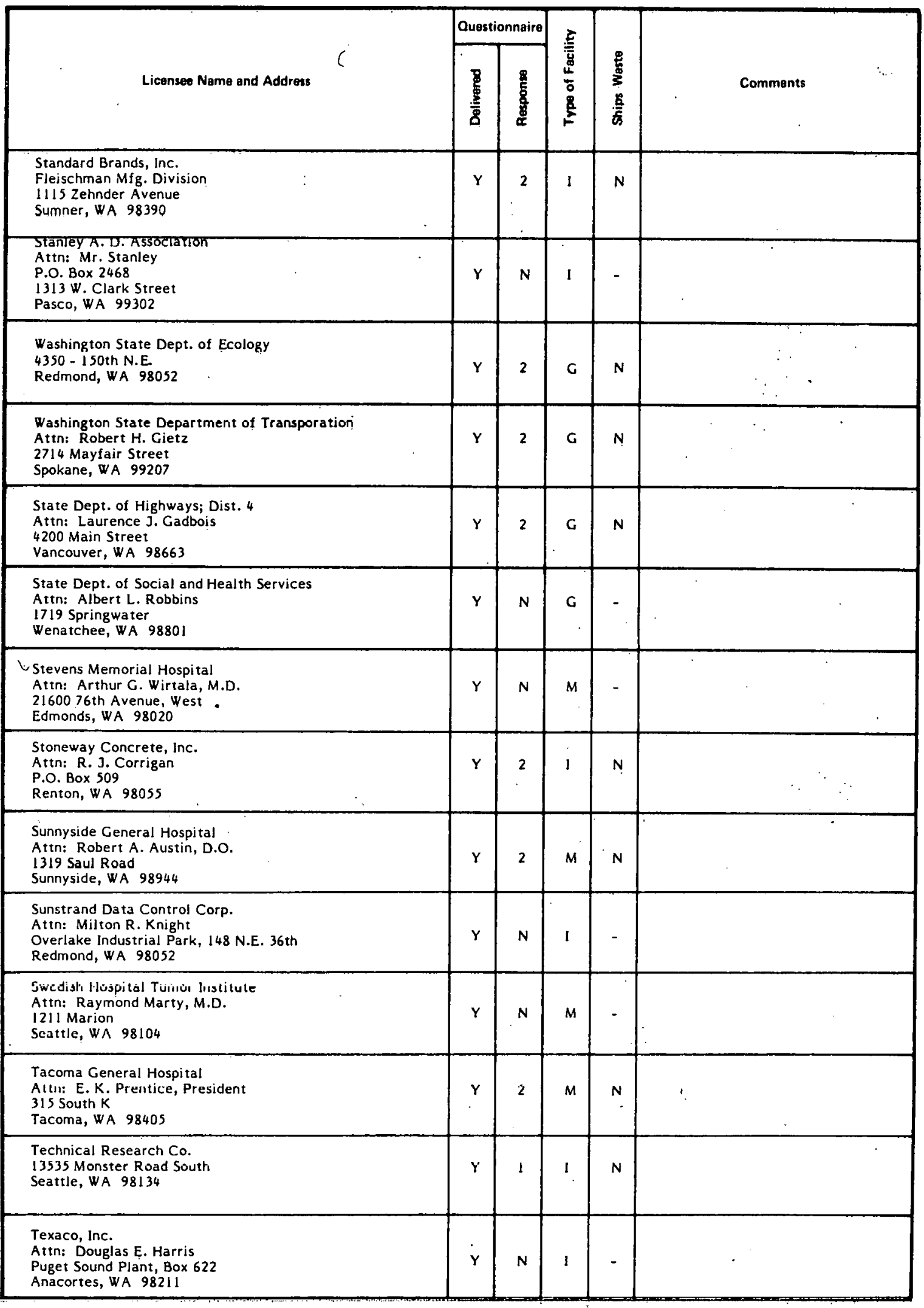




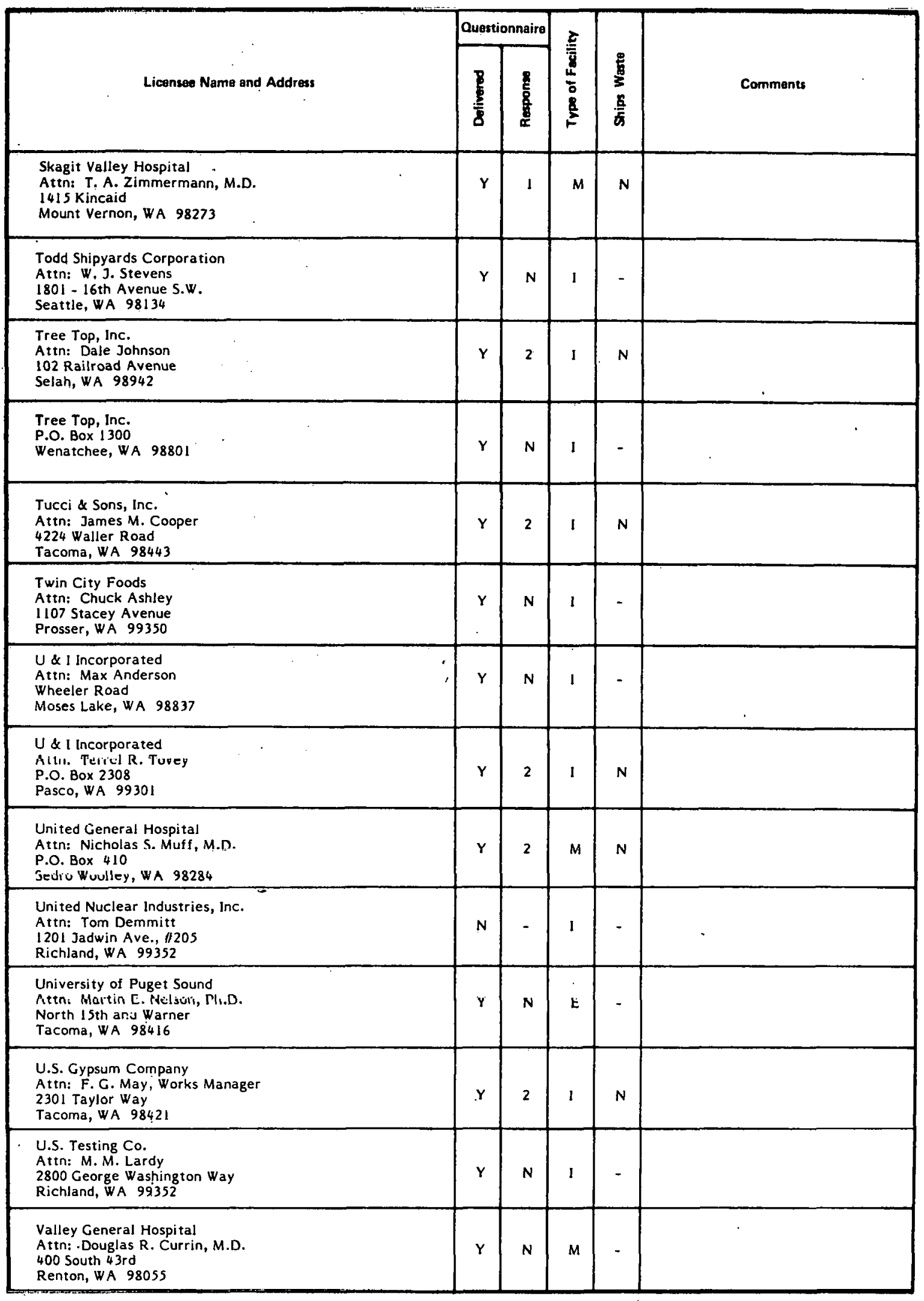




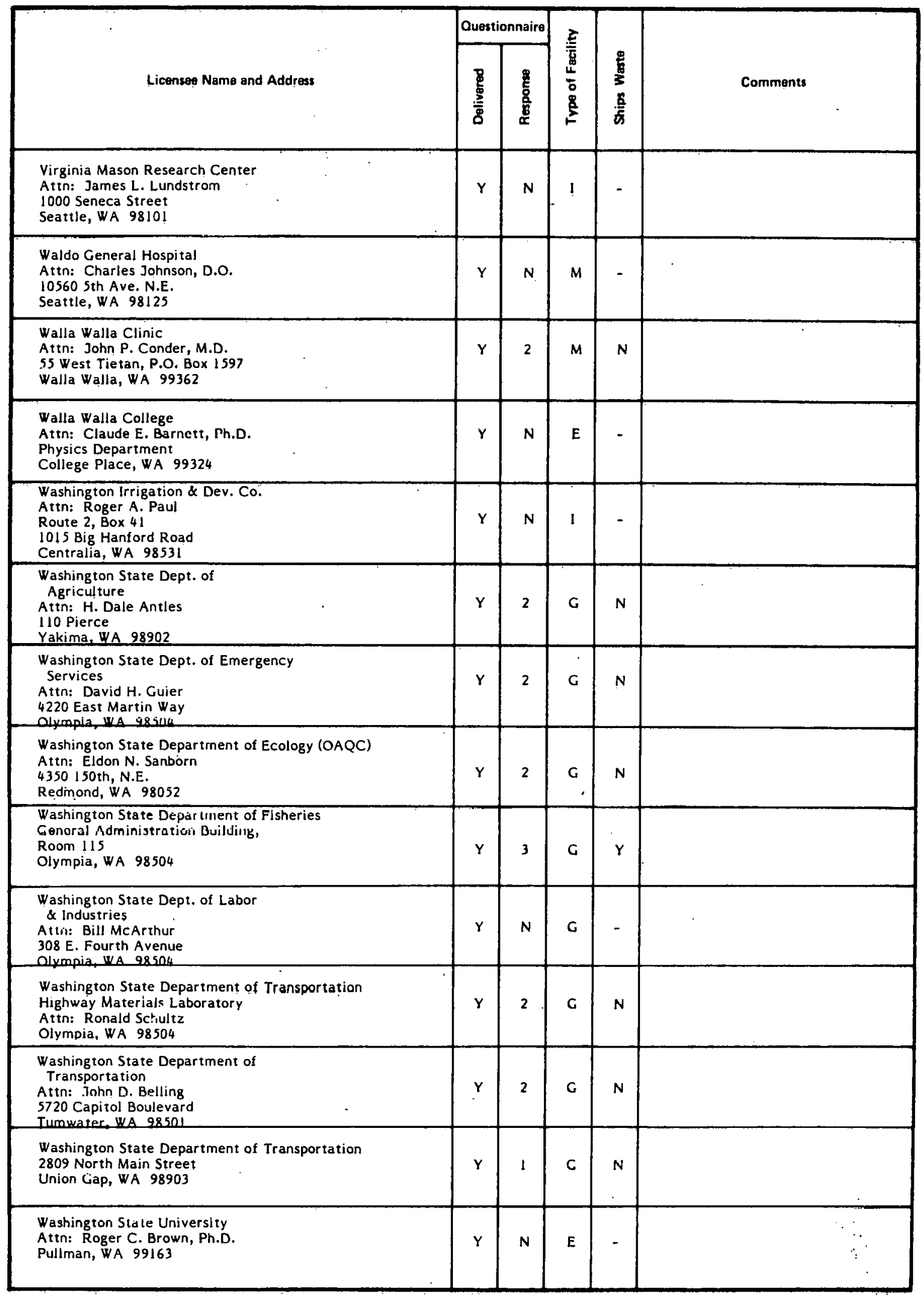




\begin{tabular}{|c|c|c|c|c|c|}
\hline \multirow[b]{2}{*}{ Licensee Name and Address } & \multicolumn{2}{|c|}{ Questionneire } & \multirow{2}{*}{ 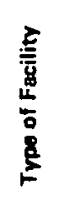 } & \multirow{2}{*}{$\frac{9}{5}$} & \multirow[b]{2}{*}{ Comments } \\
\hline & $\frac{8}{8}$ & $\frac{8}{8}$ & & & \\
\hline $\begin{array}{l}\text { WA State Highway Department } \\
\text { Attn: Ken Whalen } \\
450 \text { So. Spokane Street } \\
\text { Seattle, WA } 98105\end{array}$ & $\mathbf{Y}$ & $\mathbf{N}$ & $\mathbf{G}$ & - & \\
\hline $\begin{array}{l}\text { State of Washington Department of Transportation } \\
1551 \text { No. Wenatchee Avenue } \\
\text { Wenatchee, WA } 98801\end{array}$ & $\mathrm{Y}$ & 2 & G & $\mathbf{N}$ & \\
\hline $\begin{array}{l}\text { WA State Laboratory } \\
\text { Smith Tower } \\
\text { Seattle, WA } 98105\end{array}$ & $\mathbf{Y}$ & 2 & G & $\mathbf{N}$ & \\
\hline $\begin{array}{l}\text { WA State Radiation Control Program } \\
\text { Attn: Robert C. Will, Supervisor } \\
\text { Olympia, WA } 98504\end{array}$ & $\mathbf{Y}$ & 2 & G & $\mathbf{N}$ & \\
\hline $\begin{array}{l}\text { Charles R. Watts Co. } \\
\text { Attn: Michael R. Farrow } \\
4121-6 \text { th Avenue N.W. } \\
\text { Seattle, WA } 98107\end{array}$ & $\mathbf{Y}$ & $\mathbf{N}$ & I & - & . \\
\hline $\begin{array}{l}\text { Welk Bros. Metal Products, Inc. } \\
\text { Attn: Theodore L. Prater } \\
\text { P.O. Box } 19099 \\
25094 \text { South Hayford Rd. } \\
\text { Spokane. WA } 99219\end{array}$ & $\mathbf{Y}$ & 2 & I & $\mathbf{N}$ & \\
\hline $\begin{array}{l}\text { Wenatchee Valley Clinic } \\
\text { Attn: John T. Jenkins, M.D. } \\
820 \mathrm{~N} \text {. Chelan Ave. } \\
\text { Wenatchee, WA } 98801\end{array}$ & $Y$ & 2 & $M$ & $\mathbf{N}$ & \\
\hline $\begin{array}{l}\text { West Seattle General Hospital } \\
\text { Alth: Arthur K. Harris, M.y. } \\
2600 \text { S.W. Holden Street } \\
\text { Seatle, WA } 98134\end{array}$ & $Y$ & $\mathbf{N}$ & $M$ & - & : \\
\hline $\begin{array}{l}\text { Western Supply Co. } \\
\text { 506 2nd Avenue, Suite } 415 \\
\text { Seattle, WA } 98104\end{array}$ & $Y$ & 2 & 1 & $\mathbf{N}$ & \\
\hline $\begin{array}{l}\text { Western Nuclear, Inc. } \\
\text { Attn: George Meenech } \\
\text { P.O. Box } 392 \text {. } \\
\text { Wellpinjt, WA } 99040\end{array}$ & $\mathbf{Y}$ & 1 & 1 & $\mathbf{N}$ & \\
\hline $\begin{array}{l}\text { Western Washingtan llniversity } \\
\text { Attn: John Tuiner, Ph.D. } \\
\text { Physics Department } \\
\text { Bcllingham, WA } 98225\end{array}$ & $Y$ & $\mathbf{N}$ & $\mathbf{E}$ & - & \\
\hline $\begin{array}{l}\text { Weyerhaeuser Co. } \\
\text { Attn: J. H. Rediske } \\
\text { SOS North Pear! } \\
\text { Centralia, WA } 98531\end{array}$ & $\mathbf{Y}$ & $-N$ & 1 & - & . \\
\hline $\begin{array}{l}\text { Weyerhaeuser Co., Kraft Pulp Mill } \\
\text { Attn: N. T. Stration, Instr. Sup. } \\
\text { P.O. Box } 1228 \\
\text { Everett, WA } 98206\end{array}$ & $\mathbf{Y}$ & $\mathbf{N}$ & 1 & - & \\
\hline $\begin{array}{l}\text { Weyerhaeuser Co. } \\
\text { Attn: Bill Wade } \\
\text { Pulp \& Paperboard Division } \\
\text { Longview, WA } 98632\end{array}$ & $Y$ & 2 & 1 & $\mathbf{N}$ & . \\
\hline
\end{tabular}









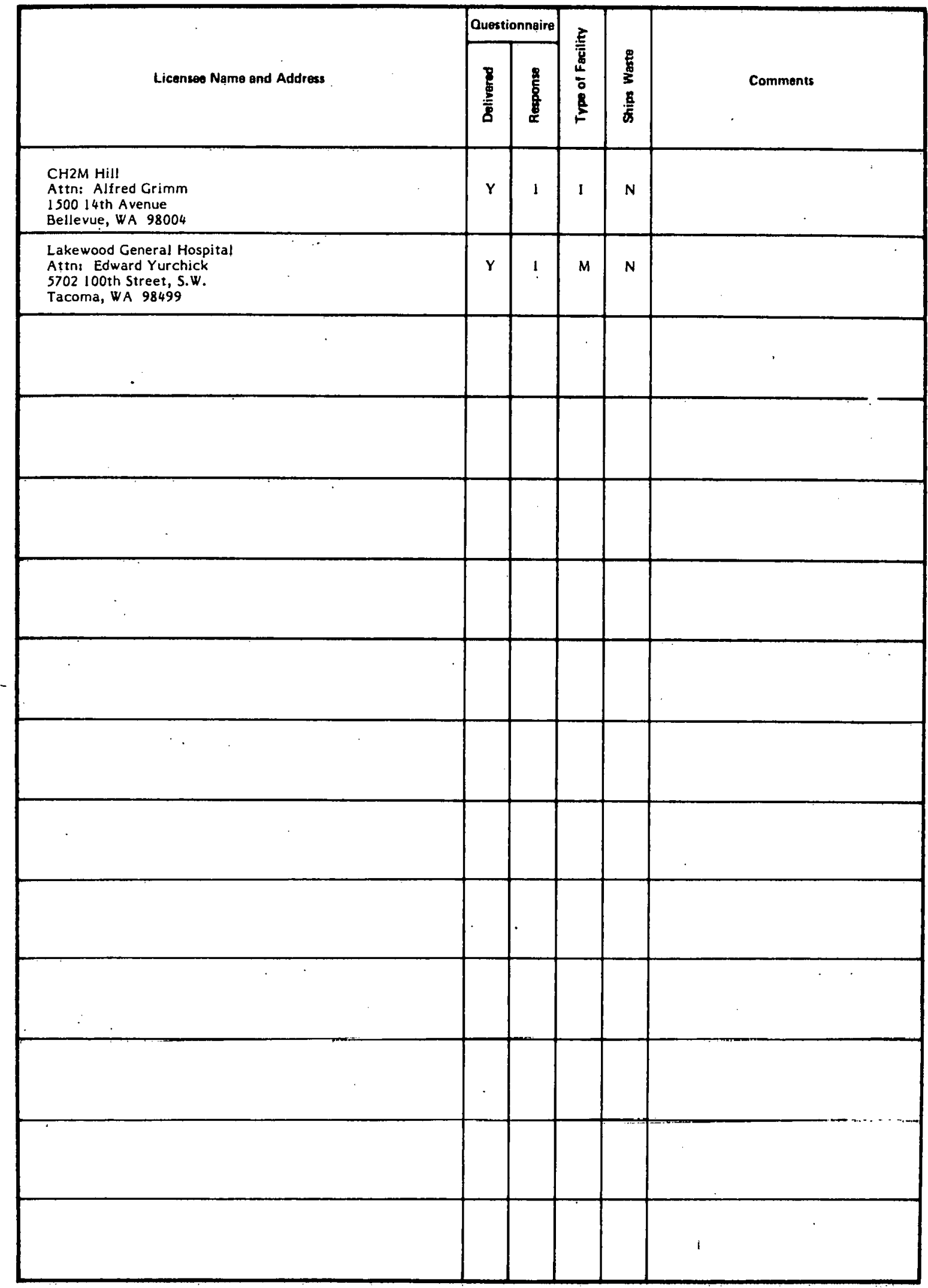


APPENDIX B

STATE LAWS AND REGULATIONS APPLYING

TO RADIOACTIVE WASTE MANAGEMENT IN WASHINGTON

B-1 
70. 98.010 DECLARATION OF POI.ICY. ' It is the policy of the state of Washington in furtherance of its responsibility to protect the public health and safety and to encourage, insofar as consistent with this responsibility, the industrial and economic growth of the state:

(1) To institute and maintain a regulatory program for sources of ionizing radiation so as to provide for (a) compatibility with the standards and regulatory programs of the federal government, (b) a single, effective system of regulation within the state, and (c) a system consonant insofar as possible with those of other states; and

(2) To institute and maintain a program to encourage widespread participation in the development and utilization of sources of ionizing radiation and atomic energy for peaceful purposes to the maximum extent consistent with the health and safety of the public.

70.98 .020 PURPOSE. It is the purpose of this chapter to effectuate the policies set forth in $R C W 70.98 .010$ by providing for:

(1) A program of effective regulation of sources of ionizing radiation for the protection of the occupational and public health and safety;

(2) A program to promote an orderly regulatory pattern within the state, among the states and between the federal government and the state and facilitate inter-governmental cooperation with respect to use and regulation of sources of ionizing radiation to the end that duplication of regulation may be minimized;

(3) A prngram to establish procedures for assumption and performance of certain regulatory responsibilities with respect to byproduct, source, and special nuclear materials;

(4) A program to permit maximurn utilization of sources of lonizing radiation consistent with the health and safety of the public.

70.98.030 DEFINITIONS. (1) "Byproduct material" means any radioactive material (except special nuclear material) yielded in or made radioactive by exposure to the radiation incident to the process of producing or utllizing special nuclear material. 
(2) "lonizing radiation" means gamma rays and $x$-rays, alpha and beta particles, high-speed electrons, neutrons, protons, and other nuclear particles; but not sound or radio waves, or visible, infrared, or ultraviolet light.

(3) (a) "General license" means a license effective pursuant to regulations promulgated by the state radiation control agency, without the filing of an application, to transfer, acquire, own, possess, or use quantlties of, or devices or equipment utilizing, byproduct, source, special nuclear materials, or other radioactive material occurring naturally or produced artificially.

(b) "Specific license" means a license, issued after application to use, manufacture, produce, transfer, receive, acquire, own, or possess quantities of, or devices or equipment utilizing byproduct, source, special nuclear materials, or other radioactive materials occurring naturally or produced artificially.

(4) "Person" means any individual, corporation, partnership, firm, association, trust, estate, publlic or private institution, group, agency, polltical subdivision of this state, any other state or political subdivision or agency thereof, and any legal successor, representative, agent, or agency of the foregoing, other than the United States Atomic Energy Commissionl, or any successor thereto, and other than federal government agencies licensed by the United States Atomic Energy Commission, or any successor thereto.

(5) "Source materlal" means (a) uranlum, thorium, or any other material which the governor declares by order to be source material after the United States. Atomic Energy Commission, or any successor thereto, has determined the material to be such; or (b) ores containing one or more of the foregoing materials, in such concentration as the governor declares by order to be source material after the United States Atomic Energy Commission, or any successor thereto, has determined the material in such concentration to be source material.

(6) "Special nuclear materlal" means (a) plutonium, uranlum 233. uranium enriched in the isotope 233 or in the isotope 235 , and any other material which the governor declares by order to be special nuclear material after the United States Atomic Energy Commission, or any successor theretn, has determined the material to be such, but does not include source material; or (b) any material artiflclally enriched by any of the foregoing, but does not include source material.

(7) "Registration" means registration with the state department of heal th ${ }^{2}$ by any person possessing a source of ionlzing radiation in accordance with rules, regulations and standards adopted by the depart* ment of health.

(8) "Radiation source" means any type of device or substance which is capable of producing or emitting ionizing radiation. 
70.98.040 NUCLEAR FNERGY PROMOTION AND DEVELOPMENT. The department of commerce and economic development through the division of nuclear energy development, known as the office of nuclear energy development, is hereby designated as the agency of state government for the promotion and development of nuclear energy in this state and shall, in addition to the powers and duties otherwise imposed by law, have the following general powers and duties:

(1) To advise the governor and the legislature with regard to the status of nuclear energy research, development, and education, and to make recommendations to the governor and the legislature designed to assure Increasing progress in this field within the state.

(2) To advise and assist the governor and the legislature in developing and promoting a state policy for nuclear energy research, development, and education.

(3) To sponsor or conduct studies, collect and di'sseminate information, and issue periodic reports with regard to nuclear energy research, development, and education and proposals for further progress in the field of nuclear energy, and the power to acquire land and faclilities for such purposes is specifically delegated to the department.

(4) To foster and support research and education relating to nuclear energy through contracts or other appropriate means of assistance.

(5) To gather, maintain, and disseminate avallable information concerning appropriate sites throughout the state and the advantages of locating nuclear energy industries within the state.

(6) To keep the public informed with respect to nuclear energy development within the state and the activities of the state relating thereto.

70.98.050 STATE RADIATION CONTROL AGENCY. (1) The department of soclal and health services is designated as the state radiation control agency, hereinafter referred to as the agency, and shall be the state agency having sole responsibility for administration of the regulatory, licensing and radiation control provisions of this chapter.

(2) The serretary of social and health services shall be director of the agency, hereinafter referred to as the secretary, who shall perform the functione vested in the agency pursuanit to the provisions of this chapter.

(3) The agency shall appoint a state radiological control officer, and in accordance with the laws of the state, fix his compensation and prescribe his powers and duties.

(4) The agency shall for the protection of the occupational and public health and safety: 
(a) Develop programs for evaluation of hazards associated with use of ionizing radiation;

(b) Develop programs with due regard for compatibility with federal programs for regulation of byproduct, source, and speclal nuclear materials;

(c) Formulate, adopt, promulgate, and repeal codes, rules and regulations relating to control of sources of ionizing radiation;

(d) Advise, consult, and cooperate with other agencies of the state, the federal government, other states and interstate agencies, political subdivisions, and with groups concerned with control of sources of ionizing radiation;

(e) Have the authority to accept and administer loans, grants, or other funds or glfts, conditional or otherwise, in. furtherance of its functions, from the federal government and from other sources, public or private;

(f) Encourage, particlpate in, or conduct studies, Investigations, training, research, and demonstrations relating to control of sources of ionizing radiation;

(g) Collect and disseminate information relating to control of sources of ionizing radiation; including:

(i) Maintenance of a file of all license applications, issuances, denials, amendments, transfers, renewals, modifications, suspensions and revocations;

(ii) Maintenance of a file of registrants possessing sources of ionizing radiation requiring registration under the provisions of this chapter and any administrative or judiclal action pertaining thereto; and

(iii) Maintenance of a file of all rules and regulations relating to regulation of sources of lonizing radiation, pending or promulgated, and proceedings thereon.

(h) In connection with any contested case as defined by RCW 34.04 .010 or any other administrative proceedings as provided for In this chapter, have the power to issue subpoenas in order to compel the attendance of necessary witnesses and/or the production of records or documents.

70.98.070 ADVISORY COUNCIL ON NUCLEAR ENERGY AND RADIATION. (1) There is created an advisory council on nuclear energy and radiation, here inafter referred to as the council, consisting of seven members appointed by the governor and serving at his pleasure. Membership on the advisory councll shall include, but not be limited to, represenatives from industry, labor, the healing arts, research and education. In addition 
the secretary of social and health services and the directors of the department of labor and industries, department of agriculture, department of commerce and economic development, and the chairman of the interagency committee for outdoor recreatlon, or their successors, shal! serve as ex officlo members of the councll. The governor shall designate from his appointees a member to serve as chairman of the council.

Members shall receive a compensatory per diem of twenty-five dollars for each day or portion thereof actually spent in attending their duties as members of the board and, in addition, they shall receive reimbursement for travel expenses as provided in RCW 43.03 .060 as now. or hereafter amended.

(2) The council shall:

(a) Review and evaluate policies and programs of the state relating to lonizing radiation.

(b) Make recommendations to the governor and furnish such advice as may be required on matters relating to development, utilization, and regulation of sources of ionizing radiation.

(c) Make an annual report to the governor.

(d) Review, after any agency, agencies, board or commission has held any public hearing required by this chapter or chapter 34.04 RCW prior to promulgation and filing with the code reviser, the proposed rules and regulations of the state radiation control agency and all other boards, agencies, and commissions of this state relating to use and control of sources of ionizing radiation to determine that such rules and regulations are consistent with rules and regulations of other agencies, boards, and commissions of the state. Proposed rules and regulations shall not be filed with the code reviser until sixty days after submission to the councll unless the council waives all or any part of such sixty day period.

(e) When the council determines that any proposed rules or regulations or parts thereof are inconsistent with rules and regulations of other agencies, boards, or commissions of the state, the councll will so advis: the governor and the appropriate agency, agencies, boards or commissions, and consult with them in an effort to resolve any such Inconsistencies.

(f) Have the power to employ, compensate, and prescrlbe the powers and duties of such individuals as may be necessary to properly carry out the duties of the councll from whatever funds which may be made available to the council for such purpose, including the power to employ an executive secretary to perform the administrative functions of the councll. 
70.98.080 RULES AND REGULATIONS - LICENSING REQUIREMENTS AND PROCEDURE - REGISTPATION OF SOURCES OF JONIZING RADIATION - EXEMUTIONS FROM REGISTRATION OR LICENSING. (1) The agency shall provide by rule or regulation for general or specific licensing of byproduct, source, special nuclear materials, or devices or equipment utilizing such materials, or other radioactive material occurring naturally or produced artificially. Such rule or regulation shall provide for amendment, suspension, or revocation of licenses. Such rule or regulation shall provide that:

(a) Each application for a specific license shall be in writing and shall state such information as the agency, by rule or regulaion, may determine to be necessary to decide the technical, insurance, and financial qualifications, or any other qualification of the applicant as the agency may deem reasonable and necessary to protect the occupational and public health and safety. The agency may at any time after the filing of the application, and before the expiration of the 1 icense, require further written statements and shall.make such inspections as the agency deems necessary in order to determine whether the license should be granted or denied or whether the license should be modifled, suspended, or revoked. In no event shall the agency grant a specific license to any applicant who has never mossessed a specific license issued by a recognized state or federal authority until the agency has conducted an inspection which insures that the appllicant can meet the rules, regulations and standards adopted pursuant to this chapter. All applications and statements shall be signed by the applicant or licensee. The agency may require any applications or statements to be made under oath or affirmation;

(b) Each license shall be in such form and contain such terms and conditions as the agency may by rule or regulation prescribe;

(c) No license issued under the authorlty of this chapter and no right to possess or utilize sources of ionizing radiation granted by any license shall be assigned or in any manner disposed of: and

(d) The terme and conditions of all licenses shall be subject to amendment, revision, or modification by rules, regulations or orders issued in accordance with the provisions of this chapter.

(2) The agency may require registration of all sources of lonizing radiation.

(3) The agency may exempt certain sources of ionizing radlation or kinds of uses or users from the registration or licensing requirements set forth in this section when the agency makes a finding after approval of the technical advisory board ${ }^{3}$ that the exemption of such sources of ionizing radiation or kinds of uses or users will not constitute a significant risk to the health and safety of the public.

(4) In promulgating rules and regulations pursuant to this chapter the agency shall, insofar as practical, strive to avoid requiring dual licensing, and shall provide for such recognition of other state or federal licenses as the agency shall deem desirable, subject to such registration requirements as the agency may prescribe. 
70.98.090 INSPECTION. The agency or its duly authorized representative shall have the power to enter at all reasonable times upon any private or public property for the purpose of determining whether or not there is compllance with or violation of the provisions of this chapter and rules and regulations issued thereunder, except that entry into areas under the exclusive jurisdiction of the federal government, or security areas under the direct or indirect jurisdiction of the federal government, shall be effected only with the concurrence of the federal government or its duly designated representative.

70.98.100 RECORDS. (1) The agency shall require each person who possesses or uses a source of ionizing radiation to malntain necessary records relating to its recelpt, use, storage, transfer, or disposal and such other records as the agency may require which will permlt the determination of the extent of occupational and public exposure from the radiation source. Copies of these records shall ibe submitted to the agency on request. These requirements are subject to such exemptions as may be provided by rules.

(2) The agency may by rule and regulation establish standards requiring that personnel monitoring be provided for any employee potentially exposed to ionizing radiation and may provide for the reporting to any employee of his radiation exposure record.

70.98.110 FEDERAL-STATE AGREEMENTS - AUTHORIZED - EFFECT AS TO FEDERAL LICENSES. (1) The governor, on behalf of this state, is authorized to enter into agreements with the federal government providing for discontinuance of certain of the federal government's responsibilities with respect to sources of ionizing radiation and the assumption thereof by this state pursuant to this chapter.

(2) Any person who, on the effective date of an agreement under subsection (1) above, possesses a license issued by the federal government shall be deemed to possess the same pursuant to a license issued under this chapter which shall expire either ninety days after the receipt from the state radiation control agency of a notice of expiration of such license or on the date of expiration specified in the federal license, whichever is earlier.

70.98.120 INSPECTION AGREEMENTS AND TRAINING PROGRAMS. (1) The agency is authorized to enter into an agreement or agreements with the federal government, other states, or interstate agencies, whereby this state will perform on a cooperative bas Is with the federal government, other states, or interstate agencies, inspections or other functlons relating to control of sources of ionizing radiation.

(2) The agency may institute training programs for the purpose of qualifying personnel to carry out the provisions of this chapter and may make said personnel available for participation in any program or programs of the federal government, other states, or interstate agencies in furtherance of the purposes of this chapter. 
70.98.130 ADMINISTRATIVE PROCEDURE. In any proceeding under this chapter for the issuance or modification or repeal of rules and regulations relating to control of sources of ionizing radiation, the agency shall comply with the requirements of $R C W \quad 34.04 .020$.

Notwithstanding any other provision of this chapter, whenever the agency finds that an emergency exists requiring immediate action to protect the public health; safety, or general welfare, the agency may, in accordance with $R C W \quad 34.04 .030$ without notice or hearing, issue a regulation or order reciting the existence of such emergency and require that such action be taken as is necesisary to meet the emergency. As specified in RCW 34.04.030, such regulations or orders! shall be effective immediately.

70.98.140 INJUNCTION PROCEEDINGS. Notwithstanding the existence or use of any other remedy, whenever any person has engaged in, or is about to engage in, any acts or practices which constitute or will constitute a violation of any provision of this chapter, or any rule. regulation, or order issued thereunder, the attorney general upon the request of the agency, after notice to such person and opportunity to comply, may make application to the appropriate court for an order enjoining such acts or practices, or for an order directing compliance, and upon a showing by the agency that such person has engaged in, or is about to engage in, any such acts or practices, a permanent or temporary injunction, restraining order, or other order may be granted.

70.98.150 PROHIBITED USES. It shall be unlawful for any person to use, manufacture, produce, transport, transfer, receive, acquire, own, or possess any source of ionizing radiation unless licensed by or registered with, or exempted by the agency in accordance with the provisions of this chapter.

70.98.160 IMPOUNDING OF MATERIALS. The agency shall have the authority in the event of an emergency to impound or order the impounding of sources of ionizing radiation in the possession of any person who is not equipped to observe or falls to observe the provisions of this chapter or any rules or regulations issued thereunder.

70.98.170 PROI'IBITION - FLUOROSCOPIC X-RAY SHOEFITTING DEVICES. The operation or malntenance of any $x$-ray, fluoroscopic, or other equipment or apparatus employing roentgen rays, in the fitting of shoes or other footwear or in the viewing of bones in the feet is prohlblted. This prohibition. does not apply to any licensed physician, surgeon, podiatrist, or any persnn practicing a licenscd healing alt, ur any technician working under the direct and immediate supervision of such persons. 
70.98.180 EXEMPTIONS. This chapter shall not apply to the following sources or conditions:

(1) Radiation machines during process of manufacture, or in storage or Iransit: PROVIDI:D. That this exclusion shall not apply to functional testing of such machines.

(2) Any radioactive material while being transported in conformity with regulations adopted by any federal agency having jurisdiction therein, and specifically applicable to the transportation of such radioactive materials.

(3) No exemptions under this section are granted for those quantities or types of activities which do not comply with the established rules and regulations promulgated by the Atomlc Energy Commission, or any successor thereto.

70.98.190 PROFESSIONAL USES. Nothing in this chapter shall be construed to limit the kind or amount of radiation that may be intentionally applied to a person for diagnostic or therapeutic purposes by or under the immediate direction of a licensed practitioner of the healing arts acting within the scope of his professional license.

70.98.200 PENALTIES. Any person who violates any of the provisions of this chapter or rules, regulations, or orders in effect pursuant thereto shall be guilty of a gross misdemeanor.

70.98.210 RECOMMENDED LEGISLATION. The agency and the councll shall study, formulate, and recommend to the legislature from time to time specific recommendations to further the purposes of this. chapter.

70.98.900 SEVERABJLITY - 1961 c 207. If any part, or parts, of this act shall be held unconstitutional, the remaining provisions shall be given full force and effect, as completely as if the part held unconstitutional had not been included herein, if any such remaining part or parts can then be administered for the declared purposes of this act.

711.98.910 EFFECTIVF DATE - $1961 \mathrm{C} 207$. The provisions of this act relating to the control of byproduct, source and special nuclear materials shall become effective on the effective date of the agreement between the federal government and this state as authorized in $R C W 70.98 .110$. All other provisions of this ar.t shall become effective on the 30 th day of June, 1961.

70.98.920 SECTION HEADINGS NOT PART OF LAW. Section headings as used in this chapter do not constitute any part of the law. 


\begin{abstract}
$J$
APPENDIX C

REPRESENTATIVE LOCAL NEWSEAPER ARTICLES RELATED TO RADIATION ISSUES AND RADIOACTIVE WASTE MANAGEMENT
\end{abstract}

C-1 
The Seattle Times

Seattle, Washington

October 12, 1979

\section{$\mathbf{N}$-plant advisory ballot is illegal, says utility suit}

\section{by BOB LANE \\ Timos stoff reporter}

Skagit County commissioners acted Hlegally in placing an advisory measure on nuclear-power plants on the November 6 generalelection ballot, Puget Sound Power \& Light Co. said yegtarday.

The company, which wants to build two nuclear-power plants near Sedro Woolley, asked the Skagit County Superior Court to remove the proposition from the ballot.

If that cannot be done, the company said, the results of the voting should not be revealed until after the county's Boand of Commisstoners has acted on a company petition to renew a eoung contract for the site.

The only effect of such a ballot proposition would be to give opportunity for more legal delays of the (nuclear) project," sald John! Ellis, Puget Power president.

"We have adready spent almost six years at the process. The ait was fled to protect all of our customers. Each additional day this vitally needed resource is delayed means $\$ 1$ million to cantumers for the cost of replacement power."

In documents flled with the court yesterday, the company sald the commissioners' action in scheduling the advisory vote was illegal because the commissioners have no authority to call an advisory election.

The company also said that taking an advisory vote at a time when commissioners are required to judge the nuclear project "could prejudice their decision."

And. Puget Power said, "certain baard actions constitute procedural irregularities and improprieties which viulale the constlutional guarantee of due process."

stapte County nearly five years. ago approved a rezone constract for the muclear-power plants. It required the company to hein construction before the five-year contract expired at the at of this year.

- Puget Power has not begun work. It has sald 12 hopes to geiye a limited work authoriation from the Nuclear Regulato.

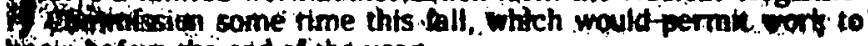
begin before que end of the yoar.

The regulatory commlssion's Atomic Safety and Ltceiving board will reconvene a hdaring on the Plget Power license requist later this topth. The setrion is expected to fo prolonged.

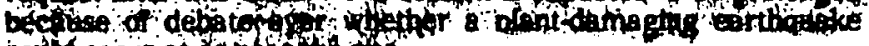

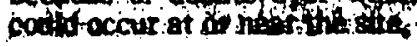


The Spokesman-Review Spokane, Nashington October 12, 1979

\section{Legislators hear $\mathbf{N}$-waste views}

BY ROEERT BAßUPT

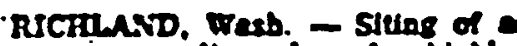
perrocoent rerites place for htghly recloscive occles wiskes will be a micb a pallical dectsten as a seleolll. te cone.

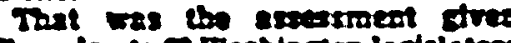
Thuradsy to 62 Festegion legtsletor by Dr. Jeto Brétesoeft J.S. Geolog.

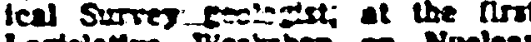
Leptsabro Wo-yasop on Noelen

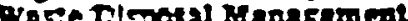

Bredehoer ras cos of is nettona axd refoad experts to cometime desacreed chappls to the cortatios cessiass of the Jout center to Gracusto Stodles about national wo clear waste palles.

Frille selestille resenreh hal-atteapied to exaroloe the meng quev thons aboot the losg tem disposal of mdiesclive wartes. Bricheboen said

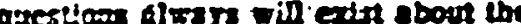
beat distoanl procens.

The mile of ine polthies 1 ortem then Thil be to weigh the that and select will be to wetch the rtate and select
But Dr. Peter Mootarve, an emtronmental aculat and fellow at the Princeton Undveraily Center lor Ener. Princeton Univetaily Center lor ciser. o and corror cuer the lederal coveraracal corle pera live neclee.

Current federal olars isollcsto cas. crection of a permanerd hica lave auclese thite storage slle, which minarily could rore extremely redioscume auclear porrer plent fuel

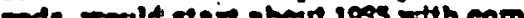

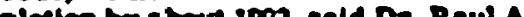
Defo, arector or en Rockingl Han. tord operalon. too Progrex.

Hanford curreoty tones dish level cuelear warte resultas brom the res. errallog's mediturs weapone producIoo and nuelcar power plant opera-

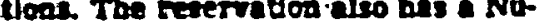
clear Endireestas Co. Ine. commen clel melent 7 nre dirpoes site, Dor cleated Thtrb hendes parardous but

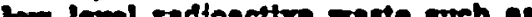
Low Level rablosctive was

poper, raga and clorhing.

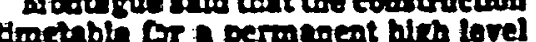

meclear wate storage ste has been atd dow before the U.S. Nuclear Rerulntor Commingion has establishd the radiation enfety standerdo to rodlatlos caloty stasdords. He real a to complato that che tederal goverameat to rubmil a leaslbillty report on a posdble permaneat hish ovel auclear wante storage alte in besalt benesth the Hanlord Reserva. Uca by 1001.

These deadilnes do "not retm jus. thed to the larce gaps of lonowledze

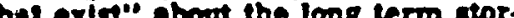
age of tuling

Tiont gre avered ithe timetables rem to represent an atrempt to repond to the Calteral hev requiring demonstration of ebe muclear waste disposal ojorem before a new nuclent pomer plunt can be licensed in Caufornile.

Gese Cramer, Southern Callforni Ecison muclesr engineer, suggested that Washington leglalators employ chels own consultant to analyze the

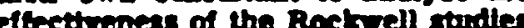
cor the feastulu of for the reasibint of a haniord 
The Spokesman-Review

Spokane, Washington

October 13, 1979

\section{Another N-waste leak found in truck cargo}

\section{BY ROBERT RARPER}

RICHLAND. Wash. - Another small leak of Iow level ridioactive waste cargo destined for disposal at. Hanford bas been defected by state tospectors at the Interstate $s 0$ eatry. polnt deat Spotane.

The disclosure came an state agencles com mented Friday a their responablillies for nu. clear waste managemeat 1078 legislators attending the final day of the first Legislative Workshop on Nuclear Waste Diposal Management.

Fashingtos state Patrol trocpare have maaned the Spokane and Plymouth, Wasb., entry polnts to Inspect all truckloads of Jow level radioactive waste dentined for Hanlor for disposal after three trucks arrived at Hanford's commerclal puclear waste site earlier this month with defective equipment or leaking radionctive shipments.

The discovery of the three shipments prompted Gov. Dixy Lee Ray to indefinitely close the Nuclenr Englneering Co. Inc. commercial low level nuclear waste ste at Hanford and order inevoctlons of all truch entering the state with low level ante to be stored at the NECO site. Cap lort HSP.
Spotane entry point found a defective barrel Wednesday in a truckload of low level waste en route from ilinols to the NECO dump.

Inspection determined a liquid from the barInspection determined a liquid from the barrel had leaked out of the truck but had dried by the time the truck was examined at the Interstate 90 chechpoint just west of the WashingtonIdaho border, sald Terry Strong, bead of the Department of Socinl and Health Services radiation and occupation health section.

Strong said the material in the defective radtonctive pharmaceutical supplies but added that the dry salt left by the

\section{N-waste}

(Continued from page 1)

leaking liquid had such a low radiation level that state officials could not measure it.

The liquid "had apparently dried across the country" en route to Washington said Strong.

"We sent it on to Hanford and we buried it."

Hart said that 18 of the Hart said that 18 of the low level radioactive waste low level radioactive waste the NECO site closed had the NECO site c

Eleven of these 18 trucks had defective equipment primarily defective. brakes, he said.

Hart also said that the TriState Motor Transit Co. Joplin, Mo., one of the main haulers of low level radioactive waste, had halted a few ghipments in Idaho to repair their trucks before they enter Washington and are inspected.
Some lawmakers on a tour of the NECO site Friday also sharply questioned the present handling of transuranics, nuclear waste which has very small concentrations of material which may remain in a radioactive state for thousands of years.

Rep. Dick Nelson, D. Seattle, asked NECO officials why such transuranics are not placed in the dump so that they could be retrieved to be reprocesscd or placed in a more secure storage site.

Thomas Baer, NECO vice president and chief safety officer, replied that the federal government had failed to supply requested information about the procedure and cost to retrieve transuranic nuclear waste, which federal officials ultimately want to store in a manner like high level waste resulting from weapons production and spent nuclear power plant fuel rods.

Alex G. Fremling, manager of the U.S. Department of Energy's. Department of Energy's Richland oversees
Reservation, added that state officials were concerned that it would not be ade quately paid to establish a retrievable process for transuranics at the NECO site.

Bacr said the federal government has established no official policy on how to handle storage of transuranic waste or its possible cost. In an earlier workshop discussion Friday on possi-

ble additional state legislation to control nuclear waste shipments and storage, Sen. R. Ted Bottiger, D-Tacoma, Senate Energy Committee chairman, said he wants his panel to examine the costs of waste storage and the.decommissioning of nuclear power plants.

Rep. John Martinis, D Everett, House Transportation Committee co chairman, said he wanted his committee to conside again a proposal to extend State Utilities and Transportation Commission regulations to private truck carriers which do not offer their services to all poten tial shippers. 


\section{Nwaste at Hanford: The future may be now}

The Seattle Times Seattle, Washington

October 14, 1979

\section{Sint muring?

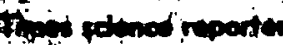

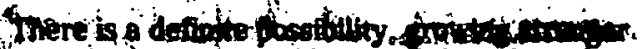
aud sonth, that a Henford ste wil heselected as one of several permanent repositorles for the no tion's high-level nuclear waste.

If that happened, it would completely change within about 20 years the role Hanford plays in helping dispose of the ration's radioactive waste.

Today. Hanford is one of three sites in the Today, Hanford is one of three sites in the
tion for low-level waste. This material, typically large in volume but low in radicactivity, is buried in shollow trenches at Hanford. (The site was closed by Gov. Dixy Lee Ray because of violations in packagting and shipping regulations, but presumably will reopen eventually.)

But if hanford becolimes a permanent roosto for hith-level commercial waste, those low-lowi A for inghils would be supplemented by shipineints of comparatively smal volumes of materia of comparatively smal volume

The waste would be formed into longtintm

The waste would be formed into longtatumg
or coramic material, sealed in statnless stee and caritied by rail in massive, shielded easks.

There could be thousands of shiprnents a year. And the Hantord area's economy would conttnue to. boon with the resulting new jobs.

WITh THAT bactdrop, 74 members of the Legislature attended a workshop in Richland Thursday and Friday for intersive briefings to Thursday and Friday for intensive briefings to prepare them

It was described as an effort unprecodented by aby Legislature to gather information on such technical problems so far down the road.

When else has a legisiative body baced decistons on a project that must be so long-lasting that another ice age must be considered likely? Or that a new geological episode of mountain building, or a

Yet, on the other hand, if Hanford finally pasees all the tests now under way and is selected for a waste repository, the Legistature would be dealing with federal agencies with such an erratic and self-contradictory record in nuclear fower over the past 20 years that is is difficult to find a five year period that didn't see a major policy switch.
In general, the legislators listened carefully and asked penetrating questions. Only occasionally cid frustration with the technicalities show.

During one exchange involving such terms as ranocuries and millirems (measures of radiation), the biosphere and background radiation, one legislator complained: "Does anyone here speak English?"

Material presented at the workshop generally ras a rehash of a dispute that has split the nation over nuclear waste for a decade:

Has the federal government finally decided where it is going and does it know what it is doing in the difficult waste-management field? Or, stung by criticism that is has failed in $\mathbf{4 0}$ years to solve the nuclear-waste dilemma, is it merely on another z:B of its zigzag path of past years?

TUNNELS mined out of solid rock in Gable Mountain near the center of the Hanford reservation have been completed, and testing will begin next spring to study the effects of heat and radiation on the rock.

The Department of Energy plans to decide by late 1881 whether it would be possible to bury wastes permanently in similit rock thousands of feet underground at Hainford. If the answer is yes,

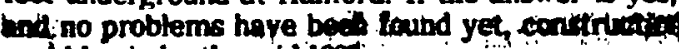
could berin by the michle it

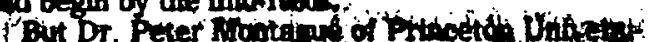

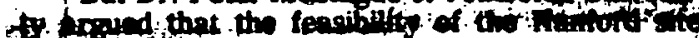
could not possibly be determined by 1981

"I am worried that the Hanford pro from in ditven by scientiftc investigation bet by in tis ditven by scientific investi

Califomia law prohibits hirtier tifing id power reactors in that state until the mucleanits. problem is solved.

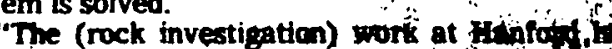
good, but just starting," Montapue sald.

But most legislators, particularly thoee intei technical backorounds, seemed imporaed with what they heard and saw of the rock studtes. They were bused to Gable Mountain and walled doyn a lon stoping mine shaft to a hollowed-out room which echoed with their voices but will soon Filled with instruments for testing.

A FREQUENT question by kegslators "How would a repository at Hand aftectititi constituents?"

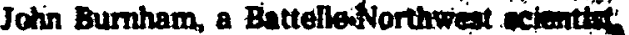
gave theru some mumbors to chew on.

The biggest impact on the conming the bitst. would be during construction. Statistroi the thits that 38 workers would low thatir tives, the ofits. surface and 37 during mithing.

Traffic accidents, mainily autotinoblles hit by waste shipments at railroed crostings, coudd b. expected to kill five persons in the first 1,000 years of operation, Bumham said. The risk from radiae tion to the public from repository operations would $x 5$ to 10 times smaller than the traffic risk.

The real impact, he said, would be on city. services to the new people and businewes that moved in. Another would be the dust involved in removing huge quantities of earth and rock trom the mine.

"More dust is the last thing we need over bere," Burnham said.

Despite the dust, Burnham said, he thought Richland residents, if convinced that adequate plan. aing had been done, would accept a repository. He added that repository effects would be almost zero tor persons - voters - more than 50 miles away.

MONTAGUE WARNED that considering nation-wide political opposition, "if the government succeeds in siting a deep repository, it would be come the only one. I think there would be great difficulty in siting four or so repositories."

Todd LaPort, a political scientist from Berke ley, warred the legislators to think about the thind or fourth generation down the road.

"If experience with a repository has been good for generations, it will be hard for people to realize the importance of being careful," he said. "Human follow-through is a big imponderable."

But federal planners say a repository, once filted and sealed, would require no care or mainte nance, only measures to keep people from drilling irto it inadvertently

Critics of federal nuclear programs are not ahways flat-out opponents of nuclear power. Mo ntague told legislators his interest in nuclear waste tems from his wife's cure from cancer.

To make sure that the disease has not re curred, he said, she must periodically take radioac tive material so strong that the law requires that her excrement be collected, packaged and disposed of in special sites.

"I am not against nuclear technology:" Mo ntague said sottly. "I am against its careless devel opment." 


\section{Mitch Miller, flat tops, \\ bologna}

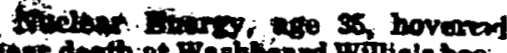

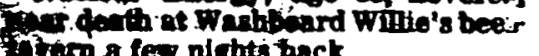

Nukes' recovery room in Washing ton state has taten on the look of a terminal ward

forn a few nights back. And nowhere was the fever more 7) filcads, the conce robust source of symbolic than at Washboard Willie's Amertcan teinological pride was this week. It seems Out-of-Fashion Arliten of the tavein with an often Fever had trickled down to even the Alti bug Out-af-Fashion Fever.

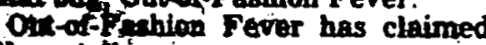
tor viction.

iltch viller, nat bops, bologns and

a nomichel succumbed to the

o thinent as of coirre, did the viet nitu Par.

Iftil, Uie fever's appearance at Pashbind Fintie's in Spokane atr- Cised Nuryes' filends.

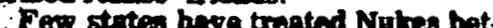
* thin Fie ingen. Nutus brought

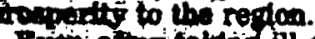

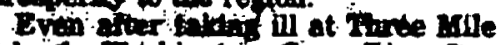

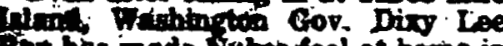
ing hes mede Nutes feel ot boute in Giscinston - intil now

If the last fer monthe grassruots cotiters of and Nuke fever have tivil trated dpea nuric Ray's Eactorn

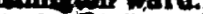

Walla Tape' Huclear Awareness Group recently picieted the Hanford atomic waste repository.

Protesters from Stuidents Against Nuclear Energy demonstrated against the governor herself in Spakane. tavern-goers and cowboys.

A bana called Wet Paint played Wilie's. They sang some good tunes but only one brought the crowd to its feet. The song was "No Nukes is Good Nukes." It goes like this:

No Nukes is good nukes, We do

Now it's spoiled for the human race; Hershey's chocolate glows in the ark,

Radiation will find its mark;

Dixy Lee says its $\mathrm{OK}$

But don't forget her last name is Ray:

There are two other verses along the same line but you zet the idea. It was rock ' $n$ ' roll politics like the days of the 1960 s and the "Fixin' To Die Rag" by Country Joe and the Fish

When rock ' $n$ ' roll bands start talking no Nukes it's not science, it's culture.

Rock ' $n$ ' roll songs about nuclear energy means Out-of-Fashion Fever has grabbed people who have no ide of the difference between fission and fishin'. The arrival of "No Nukes is

Good Nukes" signals that people in
A formal debate on the pros and Whitwarth Callege dorm only a few days ago. even smaller cities have begun looking around and seeing who is for Nukes, who is against Nukes and lining up accordinglv.

The lines are forming an around the country.

Missoula, Mont., last fall approved an ordinance banning any nuclear power plant from ever being built.

Golden, Colo., had a little proTuelear demonstration and voters in Texas said they didn't mind nuclear that much in 1978 .

Rock musicians James Taylor, Car. ly Simon and Jackson Brown raised $\$ 500,000$ this September in what they called Concerts for a Non-Nuclear Puture. Rolling Stone, Newsweek, Time and every paper in the country carried stories recently on the no-nulse work of Jane Fonda and Tom Enyden. Thoy are names from People magazine and America can relate to that.

The frantic footwork of politicians. from Jerry Brown on down wanting to lead the non-nuclear parade also illustrates how widespread the fever has become.

Washington House Co-speaker John Bagnariol is a prime example.

His office took a poll in June that suggested residents in the Evergreen State were becoming increasingly concerned about nuclear wastes accumulating at Hanford.

Once the poll showed which way the wind was blowing, Bagnariol called for a ban on further nuclear waste shipments into the state.
Out-of-Fashion Fever works fast and somewhat illogically. It gains legions who haven't studied the point being debated yet still join a side bered on the perceptions of what their heroes and cuitural leaders are doing.

Prul Rein of Wet Paint wrote ands intes is Good Nules" in 10 mimutes. But that song bas polltieized more peopio than any. 10, speeches by 8 olitucian.

In this regard, science is no mentch for Out-of-Fashion Fever. If the choic is rock stars or melear physiclets, if il be no conteat: Poople will rocl on. This irrationd herding fratrates the pro-nuke crowt. They see OuterFashion Fever as a hyped-ap frenty rought on by medin. But the germ reall bering win iriendly enviromment

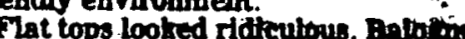
and banana sandwiches tasted The Vietnam War was poorly epAnd nuclear power woulitn's: be. tricken by Outaf-Fashton Feve if Three alle Island had not happeried and if the promises of low-cot aucied and if the promises of low-cout bucter energy could be fulfilled.

The fever is rising now, carried of a cultural momentum that the support of nucleat Nukes, ol' boy, do you have any bast wonds? 
The Spokesman-Review

Spokane, Washington

October 15,1979

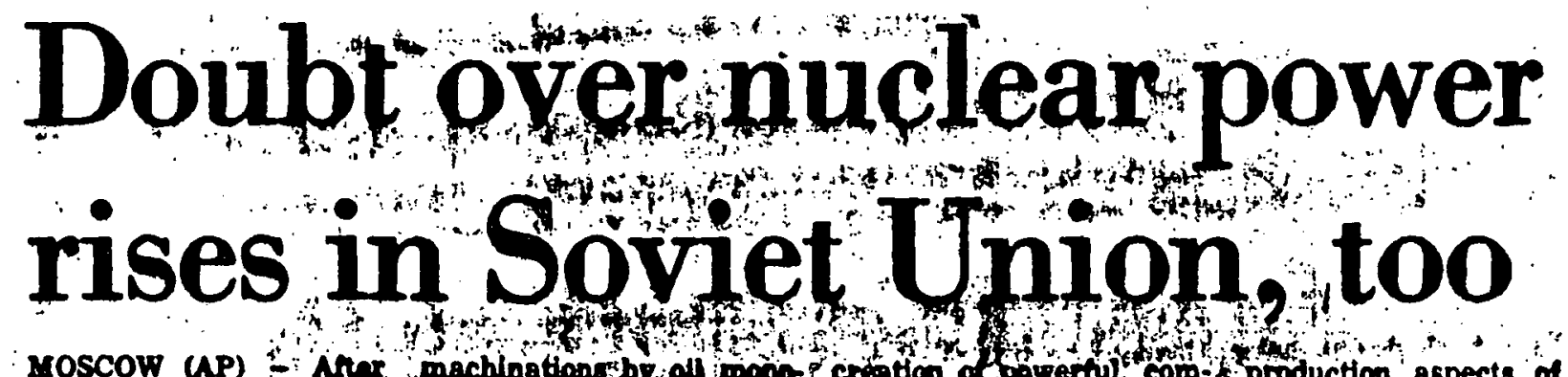

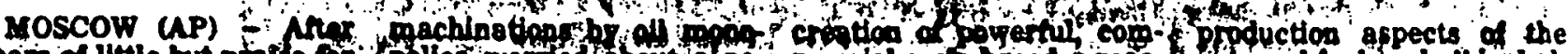

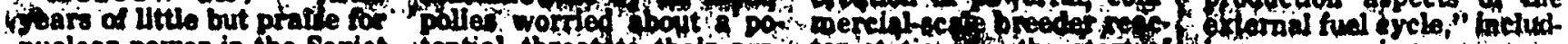

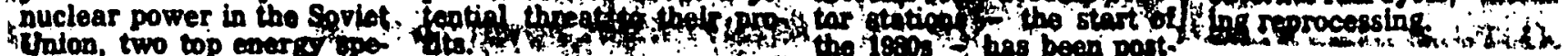

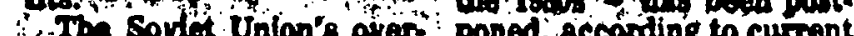

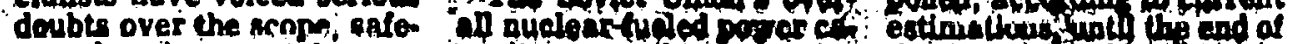

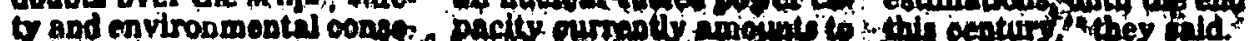

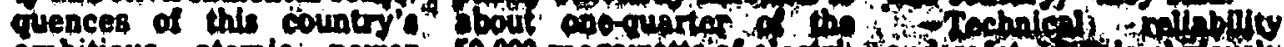

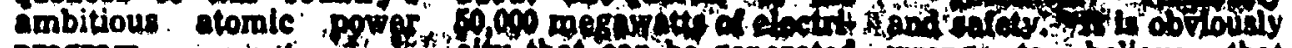
prosram.

Unless the program in radically altered, they $\mathbf{s w}$ more densely. populated arear of Evropean Rúsid

1 maj 800 n roseb the limits of

"their "ecological capacity"

Aff that can be generated wrong" to "belleve that

by atomic power stations in guaranteed, F reliable, ecothe United States:- in nomical

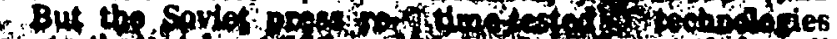

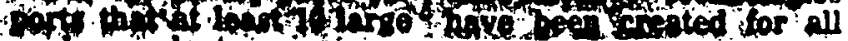
nuclear a plants an ; now to cope with now nuclear, profocted oppelts a pore s ponper stations. They also caution th would Upoa completion. hy the

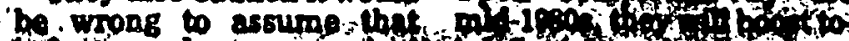

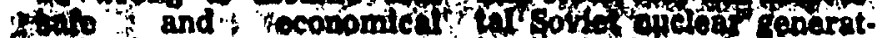
Ftechnologies have been de ing cppaclt pove 35,000

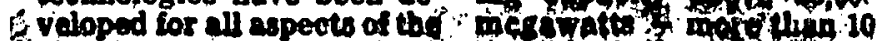

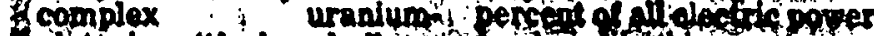

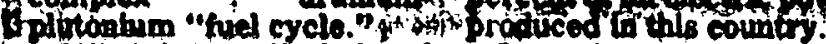
Mikolai A. Dollezhal and

Yurt Kotyatin sounded the

- waming in an authoritative

$\therefore$ article published in last

week's edition of Kommun.

ist, the Soviet Communist

r Party's leading theoretical

- journal. Koryakin is an

cconomist and Dollerhal 1

- chiaf of a department of the

Sovlet Academy of Science.

- that deals with enerry pro

rduction.

In U.S tarms thet is

pouph eloctriclit to pouper

about 00 cites Dhe 8 ise of

Boston ar St Lovil s?

In their detalled a, 000 word article, Korgatin and

Dallezhal 'balapced' both pralse and critician of ou. clear powar ofs of on

They sald modern atomic otation can prodicios power mor ecoponilcall o than conventionalls dred thots. Western . scientilic reduce the appendpetrons

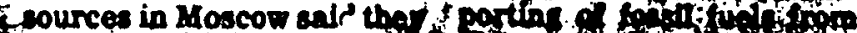

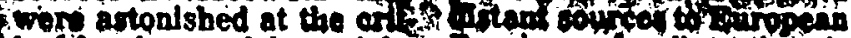
Aical frankmess of the articla, iusia, and pollut the air - which contrasted sharply less than plents burning co-

is with the upbeat tone typled al or ofl And they asserted

of most nuclear power that in viow of declining fos-

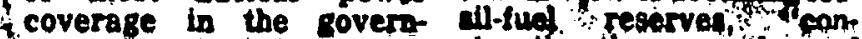
ment-controlled news tructing the eqerpiche of imedia.

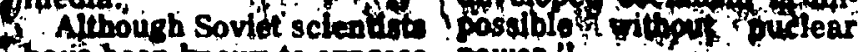

Thave been known to express - personal misgivings over atomic. power privately. thers is nothing in this coup-

try resembling an organ'lled, public anti-nuclear Lobby.

power." ? At the same theng, powov.

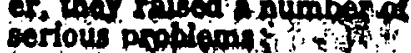

- Delay in th devalop ment of "foth preeder"

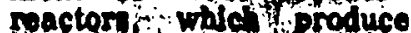

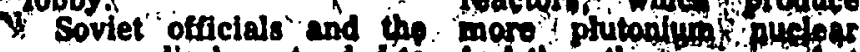
new media have tended to . fud thon the conping but Sascribe the anti-nuclear requir camplen hal repro-movement in the Weat to cossing faclitiog on the pro-

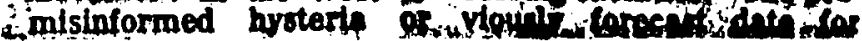


The Seattle Times

Seattle, Washington

October 17, 1979

\section{More Trojan N-plant opponents arrested}

SALEM, Ore. - Five more members of the Trojan Decommissioning Alliance didn't have any more luck yesterday trying to get the Trojan nuclear power dant shut down permanently than did four of their cohorts the day betore.

And all nine of them ended up in jail for their trouble.

The latest arrests came as the members again retused to leave a state office (the governor's) when . business hours ended.

Four other members of the Trojan Decommissioning Alliance were arrested Monday when they refused to leave the offices of the state's Department of Energy. 


\section{Hanford site closed till at least Nov. 6 - Ray}

\section{bY LYLE BURT}

Times Olympio burnou

OLYMPIA - Despite a federal offer to step up safety inspections of nuclear-waste shipments, the Hanford disposal site will not be reopened at least until November 6, Gov. Dixy Lee Ray said yester. day.

The closure will continue to apply to both out-of-state shipments and radioactive waste generated within the state, she said.

"I don't think it would be appropriate to open the site piecemeal," the governor said.

Her statements came after a two ficur meeting with ullicials of the Nuclear Regulatory Commission, the federal Department of Transportation and the University of Washington.

One of the principal problems, Goveriur Ray sald, is that in about half of the states, the N.R.C. does not have jurisdiction over the handling of nuclear waste.

She said a procedure is being developed with Govs. Richard $\mathrm{Ri}$ ley of South Carolina and Robert List of Nevada $b_{\text {; }}$ which the three states, which have the only low level waste-disposal facilities in the nation, could exercise contro of waste shipments from those states.

The procedure, expected to bc worked out within a few days, would require those states to sign certificates of compliance guaranteeing that their shipments meet federal safety regulations.

It will be discussed when the three governors meet with N.R.C. officials in Washington, D.C., No vember 6, Governor Ray said.

William Dirks, director of nu. clear material, safety and safeguards for the N.R.C., said his agency recently had expanded its authority.

"We are prepared to step up our inspections for proper packaging," he said.

"We talked about the governor providing us with definite inforination on where violations are uccurring, and then we'll take action," he said of yesterday's meeting.

"We have enough authnrity to take action against states with N.R.C. agieements."

Governor Ray shut down the privately operated Hanford site October 4 because three trucks carrying out-of-state nuclear waste were found to have either defective equipment or leaking containers.

Governor Ray said yesterday's discussions centered on how. waste shipments are packaged and made, where entorcement authorIty lies and what the various agencies can do to assure proper packaging and shipment. The officials also discussed the new contract the state is negotiating with Nu clear Engineering Co., operator of the Hanford site.

We received assurance from

N.R.C. of assistance."

Asked about the radioactive waste that is accumulating at the University of Washington Hospital, the Hutchinson Cancer $R$ e search Center and other facilities in the state, the chief executive replied:

"I understand there is same inconvenience, but I believe the sit. uation is not truly critical. Most places where they use radioactive materials have some facilities for keeping the waste on sito."

She said the field of medicine is most seriously affected by the Hanford closure.

Dr. WII B. Nelp, head it the division of nuelear medrcinte of this U.W. agid that the Hutehinson Center has a storiege problam.

"But, I think ht is of no danjor to health." Dr. Netp said.

"I think the medical commantty is supportive of the governar's po. stion," Dr. Netp cald, odding tot the profession can live wh the November 6 date.

Dr. Nelp said the divcusolion: were preliminary and wo firm ean. clusions were reeched.

"We talked about what the lod. eral agencles can do and what the state can do to help with the (waste) transportation problem," he said.

(Eartiar stary, D 7) 


\section{Cream, sugar, nuclear power}

By RICL BONWNO

This Thursday evening. Judy Long and about 20 of wer friends and neighbors wame home drink somo coffabe home, drink somo cofpower.

That's hardly a typical topic for a coffee klatch. But the scene will be repeated thousands of times across the country as Nuclear Energy Women sponsor their first Nuclear Energy Education Day.

The day's scbeduled Thents range from a mass events rango from a mass Washington, D.C., luncheon or congressional wives at which Margaret MrCormack, wife of Eastern Washington Democrat Mike McCormeck, will hosteas.

Stlll, most of the nctrt sions will consist of infor. mal discuscinns in prisate homes such as Mis l.meng And ifrs lonk it Wiathing. ton Water Power Co. public it was very impressive."
relations person, expects Mrs. Long said of her visit relations person, expects her gathering will be the only one this aide of McCormack's home in Richland. Wash.

It seems a lot of people don't care one way or the other about nuclear power. While she': worked for WWP for three years, Mrs. Long hasn't paid that much attention to it herself unitil

just recently.

I'm atil very, very, very new at this," she said Tuesday. "Now, I almost feel like a sponge, soaking up information wherever I can."

She soaked up a lot last month at the annual confer ence of Nuclear Energy Women in Richland, where she first contacted the worr.

en's group and then toured the

Scuing tou much power could be gencrated, the simount of haste produced compared to other sources. to the Hantord reservarion. 'Sometimes, doesn't just seem like everything is hopeless?" she continued. "It seemed like here was some hope."

Ever since, she's been climbing higher on the nuclear power bandwagon. joking that her family is "bored stiff" with her dis coveries.

But Mrs. Long thinks the nation's energy future is nothing to yawn about. I like 10 go to the light be based on lacts, not bys-

switch, turn it on and have teria," Mrs. Long said. the light 80 on," she said.

National NEW Chairwo

Nan Ruth Paulker puts the problem in a perspective provem in a persective one Mrs. Long heartily supports.

"The use of electricity in the home has been one of the principal factors in liberat ing women, allowing them to develop their own interests and lifestyles," Ms. aulkoner said.

There'll be at least one man at Mrs. Long's home Thurgday, a former Hanord employee named Bob Mansfield who now works at wWP. She said Manslield will provide some be provion. 


\section{Test-ban treaty could close Nevada nuclear test site}

LAS VEOAS - (AP) - From a paring car, clues are tew. Craters gape here and there. An occastongl sigm, prominently posted on a fence, warns of radioactivity.

It is the desolate Nevada Test Stre a scant twohour drive from the bustling Las Vegas Sirip and the scene of some of the world's most awesome displays of mili. most awesom

Sprawled over 1,350 square miles of arid, sagedotted deser and rugged mountains - an a rea roughly the size of Rhode Island - the test site since 1951 has been jarred, shatoen and battered by 54 of the 670 nuclear tests anrounced by the government. Not all tests are anounced.

The powrer unleashed in 28 The power unleashed in 28 years of nuclear tests is beyond comprehension. At least four of the warheads have been in the a million tons of high explosive.

The total high-explosive yield from the rest of the shots is be tween 11 million tons and $30 \mathrm{mil}$ lion tons. The exact figure :s classified. When the Department of Energy announces a test now, it usually says prily that the wartead had a yield of 20150 kilotons.

BY COMPARISON, a single So vitet atmospheric test on October 30 , 1801, had a yield of 58 megatons - 58 million tons o: high explostive; the largest nuclear test ever conducted.

Nuclear blasts here would come to a halt if accord is reached in the ongoing lest-ban negotiations among the United States, the So- vie: Union and Brite in. But Mah lon Gates - the former Army brigadier general wo heads the test site - says it will be kep ready.

The Department of Energy would bave "to maintain a capa bility for retuming to urderground tests" even if a camorehensive tests even if a comprehensive said.

"We would be required to re tum just as a precaution if the other side, for example. violated the treaty and retumed to test ing," he said. "And I presume that there are other scenarics that on could develop that might cause the United States, for its uwn best interests, to retum (i) nuclear testing."

Gates believes chances of approval of a test ban will improve if the embattled strategic-armslimitation treaty is ralified.

"I think the prospezts of reach ing an agreement wit? Pussia are relatively high if the Senate rat lies SALT II. he said "Fallure of ratifeation of SALT "F. T would say, would cast some dount on the probability of reachirg an accor on a comprehensive Iest-ban Ireaty.

The test shots are conducted for - vartety of reasons, Gates said in an interview. While "tremendous amount of work" is done in daboratories to perfect nuclear devices. "es the perfect nuclea devices, carried uut in ine still the actual teat 0 me dus nut have che actual test. dine des not have sufficient confidence son in simulated testing to preclade the ne-

All the tests are expensive, he said ranging from a low of 11.5 million to as much as 850 mill on. "There is no average," he added. "There is no average," he added. Gates administers a $\$ 225$ million budget and heads a work force of more than 5,000 persons, ranging Irom nuclear physicists to the vel drillers and hard-rock miners who bury the warheads deep anderground.

Gates said that if nuclear testing is banned it would cost 800 to 200 jobs.

Gates said the job gaps left by a test ban might be filled by other projects, such as the "nuclearmarbage dump" for lo garbage dump" tor low-level raDed at the site by the Energy Department. The waste, from varicus govermment facilities, is buried in renches.

THE TEST STTE also is under consideration as a site for dispasing of high-level radioactive waste ing of high-level radioactive waste plants. A research project aimed at determining the best metho-1s of storing the rods is now under way at the gite.

Since 1962, all tests have been conducted underground. Earlier atmospheric tests, chiefly those conducted in the mid-1950s, sent radioactive fallout drifting across Scuthern Nevada, Southem Utah ard Northem Arizona. About 600 claims have been filed by families of persons stricken with various. forms of cancer possibly linked to the fallout

The underground tests boast a relatively clean safety record However, 21 shots have accidentally "vented" radioactivity. One lederal lawsuit, reporting two test-site workers died of cancer dure to radiation from one such incident, was tried earlier this year and has been taken under submission by a judge.

Gates said a "containment evaluation panel" considers all upcom. ing underground tests to gauge the chences for tests to gauge the tive une wouldn't detonate unless that ... panel recommends that: we do detonate," he said. 


\section{Ray keeps N-waste site closed}

\section{D) ROBERT EARPER}

OLYAPLA - Finford's low level commercial nuclear waste 'dlsposal
site Utely will remalu closed unul at site Itrely will remala closed unill at Tuesday.

Ray made the comment after talking privately tor about two boure with federal ofticials about stricter enIorcement of the transportation and packaging of low-level nuclers. pastes.
Ray said there was no possibility that the Hanford disposal site, which Is operated under state license by the Nuclear Englneertig Co. Inc., could reopen before ber Nov. 6 Washington. D.C., meeting with the U.S. Nuclear Regulatory Commission.

Thls November meeting also will Include the governors of South Caroli. na and Neveds, where the nation's two other commerclal low level nuclear waste sites are located.

"We are moutos as cuterly as can l" ald Ray of (atate) proposals to can,I said hay of (state) proposals to improve inspections of low-level nuclear wasto shipments.

Thy guees is that wo should ture the (state's) certifleation plan (lor low level uuclear waste shlpments) pretty well worked out in the mext few days," the covernor cald.
She added that she did not consider it appropriate to open the Banford crmmercial nuclear disposal site on a "precemeal" basis to allow Washington State producers of nuclear paste to use the Hanford sito before ont-ofstate producers could do 80 .

Dr.Wil Nelt, head of the Untversity of Washington nuclear medicine division, sald the fanford commercia divislon, sald te Faniord commercia eace but that Nov. 6 would be "an ideal date" lor its reopening.

He sald that a long term clocring of the Fanfard disposal site would present a problem of the stornge of auclear wastes at a facility acb os Seattle's Fred Butchloson Cancer Bo search Centor.

(Contioued w inger) defective truck equipment.

\section{Hanford}

But he added that a number of per. conis to the medical flold in the state "are very supportlve" of the governor's effort to obtain stricter enforcement of nuclear waste transportation ond packaging.

William Diris, NRC director of auclear mnteriall safety and safecuards, said the agency had expronded its regulntary power recently by assuming foint authortty with. the U.S. Department of Transportation for enDreme niviear warte corcement of Don

Dirts gald the the ageney hed add Dirks sald that the ageecy bad adda II persons to its enloreement seccon to bring it wotn aumber or NRC ouclear waste. shipment inspoctore to about 70. Hore infpecturs aro roquested in next year's federal budget.

Whillo these binpetors murt overses bout 8,000 entrties licuted to pererge and chlp low level nuclear waste, Dirks saild there are only about 200 to 300 major nuclear vaste packerers and shippers.

He ald the sovercor presinted to NRC and DOT officlals Tuesday a plan calling for state enforcemeat and inpection of low level nuclear. wente shipments and for a waiver of a thipper's federnl rohts to permil tato enforrement to be cruded out byend Teahington boundaries. Weahington boundaries.
But Dirls poloted out thet it wonid be difo cult for tho lodernl sovornment to try lo enforce Washington cltation and transportation outslde of the tate.

NRC, bowevar, plans to itep up ita

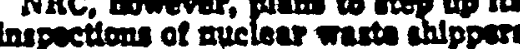

page 1) 1)

and producen whow palan das of mo clear waste had been fourd defletent by Washlngton oflletuls, to sald.

A nuclear waste shipper-producer cound in violation of leceral regula. tions by Whashington offictals would be "high on tho list of (NRC) inpece lons," gald Dirks.

Ho sald the NRC already can mato enforcement change th the 25 state wher the commission direcely super.

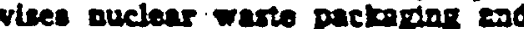
chipplng.

But Dirlo acted that NRC otheinl. nlan to present a propasal at es . No . 6 in Washington, D.C. to tlentwecelor in Washington, -D.C., to traten cupervaton or auclear waste pacwhe and shpplas la lus 25 exaces.

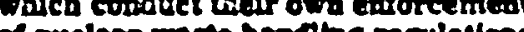
of puclear wasts brocibas reculations under lesteral agrimanta. 
The Spokesman-Review

Spckane, Washington

actober 17, 1979

\section{$N$-sabotage brings conviction}

SURRY, Va (AP) - Two selfSURR, Va. LAP) - Two selfprofessed saboteurs were convict-j Tuesday ol damaging a nucleas wer plant in whin was believed De the first trian in the nation colving the r facility.

The jury returoed guilty verdicts against the former Surry nuclear plant employees after deinerating lor abolt three hours. The two men had admitted pouring a caustic chemi cal on fuel rods a: the plant. saying they wanted to dzaw atteation to what they said a:e lax safety standards.
Virgtnia Electric \& Power Co. has estimated damage to the plant at $\$ 1$ million.

Convicted on single felony counts of damaging a public utility were William Kuykendall, 26, of Newport News, and James Merrill, 24, of Hampton.

The jury recommended the minimum sentence - two years in prison - but the judge need not accept the jury recommendation. The maximum sentence for the offense is to years in prison.

Kuykrndall and Merrill, former control room operator trainees at the nuclear plant, admitted they

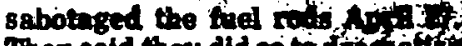

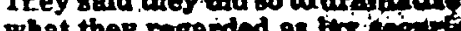
tyat thes regarded as ix at the plent. plant.

The trial befare Jude iliven Jones began Thursday the this ri: al Virginia community.

Earlier, Ligon disnd ind other charges agatort buf tewden. and Merrill: He. olso . miled. tha they could tomtify as to chorr the of mind at the time af the wabiage, but satd they could ant the cuss safety conditions at the wo. clear plant. 
The Seattle Times

Seattle, Washington

october 19,1979

\section{Power rationing in 2 to 3 years?}

\section{- bY LYLE BURT}

Timos Olympio bureau

OLYMPIA - Electric energy will have to be rationed in Wash. ington two to three years if the demand for it continues at the present rate, Jack Wood, state energy direcior, predicted yesterday.

"We haven't brought enough new power, plants on line and we haven't done anything to dampen the demand," Wood sajd.

Contending that conservation still is the key to the electricity problem, Wood said:

"For the long range we have to look at other energy forms for space and water-ineating. perhaps for pumps used to drive irrigation systems and other uses.

If Washington's growth rate continues at the present 3.9 per cent a year, "in 18 years avery source of generating electricity will have to be doubled," he said.

Even if construction of the Washington Public Power Supply System's nuclear plants proceeds with no further problems, Wood said, "by the time the plants are built the total electric-power supply will be inadequate to nieet the increased demand."

Wood's statements came on the heels of a reyus.st from the Puget Power and Light Co. for the State Utilities and Transportation Commission to provide guidelines for rationing electricity.

John Ellis, Puget Power's president, said his company faces an electricity shortage in the next decade. He said the state should begin making decisions on how 10 curtail use of energy, or ration it.

THE UTILITIES and Transpor tation Commission issued a direc- tive to Puget Power yesterday to produce justification within 60 days for its request for public hearings on the predicted electricenergy crunch.

Commission Chairman Robert Bailey said by the time that justification is received and public notice of hearings is given, it will be close to the end of the year or after before hearings can be scheduled.

Although Wood said it is not yei "time to panic" over a possible electricity shortage next year, be cause of inadequate rainfall, he warned Wednesday that the state could face shortages next year.

A SIMILAR, but evén stronger wirming, was issued at Portland jesterday by Herschel Jones Seattle economist and president of a consulting firm.

"There is not gning to be enough power in the Pacific Northwest to serve all the custom ers in the region," Jones told the Portland chapter of the National Association of Business Economists.

"There may not be enough power to serve all of the loads next month, next year and possibly never again," Jones said, as United Press International reported.

Wond said scme of the problems plaguing this area include the inability of Washington to purchase surplus nower any longer from Califonita in periods of low demand in that state, and the tendency of home builders in suburban or rural areas to install electricity for all home utilities.

The latter probiem, he said, stenis from the rapidly increasing price of fuel vil and the lack of natural-gas dist ribution systems in many suburban and rural areas.
bY SUSAN GILMORE

Times staft reporter

Against the backdrop of a needed upward tum in a key presidential-popularity poll, Rosalynn Carter told supporters here yesterday that her husband intends to run for reelection and intends to win.

It was the same message, in many of the same words, that she carried to Democrats in Portland and Spokane.

The Seattle visit, hastily planned over a three-week period. ended a two-day Northwest fundraising swing for the First Lady. She returned to Washington D.C., this morning.

Evan Dobelle, chairman of the Carter-Mondale reelection committee; commented on a poll by Associated Press and NBC-TV. disclosed last night, showing the President gaining in popularity. "Things are going the other way ... there's a dramatic change in the polls." he told some 75 Carrer supporters at a dinner at the Olympic Hotel.

Mrs. Carter's remarks were concise - she is stumping for the President, is not concemed about the low public-opinion polls and is confident her husbend can defeal any Democratic challenger for the nomination.

JUST FOUR days ago, several prominent area Democratic politicians and labor and minority leaders announced a Senator Edward Kennedy for President campaign.

Mrs. Carter said the timing of that announcement had nothing to do with her trip. "It's immaterial to me ... who else runs," she said. "If (Kennedy) chooses to. rul, we'll beat him."

She said challengers have helped "coalesce" the Carter campaign, and that more excitement has been generated "since Kennedy made his move. Every. body is ready to go out and fight."

When asked whether cerrain congressmen may need to ride Kennedy's coattails to victory next year, she said they had "better stick with the President. 


\section{N-waste disposal 'frustrating'}

SEATTLE (AP) - The disposal of nuclear wastes appears to be "readily solvable" but at the moment "is a matter of considerable Irustration to much of the scientific community," an energy expert and University of Washington physics protessor said Thursday.

Dr. David Bodansky, an internationally noted expert on eaergy, said it's up to the federal government to devise a clear program for atomic waste disposal. But he also said it would be "particular folly" to abandon nuclear power when, despite problems, it shows "great promise as a safe. clean, and economical energy source."

Bodansky said that until the goverament makes a decision as to which of several acceptable nuclear disposal paths to pursue. "it is fair to say that we have no plan for the disposal of wastes."

Politics should be removed trom the equatlou, be said.

Nuclear waste disposal "should be addressed with greater administrative vigor and with a wlllingaess to have our program be de. termined by sound technical and scientific judgment, rather than by political expediency." he said.

Washington Goy Dixy Lee Ray recently closed the private low-level nuclear waste disposal site at Han. ford becausetrucics were found to be carrying impro. perly packaged nuclear waste cargo.

Bodansky also noted that coal has its own wastedisposal problems, partiru. larly what to do with carbon dioxide which forms in the combustion of iosail fuels.

"The (carbon dioxide) problem bas raised a cloud over future heavy reliance on fossil fuels, and particu. lariy on coal because ther is so much of it," he said. "Thus, while the United States could embark on a substantial expansion of co al usage, such a policy could prove to be dengerous if emulated worldwide, or contipued for many decades," he said.

Bodansky said America should pursue all energy op. tions into the $218 t$ Century including conservation, renewable resources, synthetc fuels, coal and nuclear power.
He spoke to the Puget Sound Energy and Utillties Committee. An organization called Nuclear Energy Woman, representing number of women in nuclear industry, designated Thursday as "Nuclear Edu. cation Day" nation wide. 


\section{Councilmen differ over nuclear study}

\section{by ROB LANE \\ Tunes stoff reportin}

The City Council Energy Com. mittee divided yesterday over doing a study comparing the cost effectiveness of three nuclearpower plants with other energy sources.

The committee also could not agree whether environmental studies should continue for a proposed dam and powerhouse at Copper Creek on the Skagit River while geologists search for earthquake faults which could prevent the project.

The full Council will decide both questions, probably October 29.

Councilman Randy Revelle. committee chairman, and Councilman Michael Hildt, spent the long Eossion in disagreement.

Revelle, City Council President John Miller and Mayor Charies Royer last summer asked City Light Supt. Robert Murray to prepare a plan for an independent analysis of the cost effectiveness of three nuclear plants being built by the Washington Public Power Sipply System, and of alternate energy sources.

Members of the Light Brigade and other groups have said they hope the studies would lead Seattle to abandon participation in the nuclear projects.

Yesterday, Revelle said that for the study to be accepted by other utility officials in the region. it would have to involve the supply system and the Bonneville Pover Administration.

He proposed Murray be given two months to negotiate a study agreement: if he is unable to do that, the Council then would consider whether the city should do the work itself.

Revelle said there is no way for Seattle to withdraw individually from the construction project. If the plants are to be abandoned, it must be the decision of the utili. ties which make up the supply system, he said.

Hildt, critical of the "conventional wisdom which has brought us to this point," said that if Seattle did the study well, it could go the supply system board. "We would be in a good position to convince others," he said.

Hildt argued for a commitment to do the study now and said Murray should be given a month to arrange a cooperative research project.

Murray said the study would cost about $\$ 175,000$. Most of the work would be done by a consulting tirm.

The controversy over Copper Creek began a few weeks ago when City Light consultants said they had found that active ground faults may exist near the dam site, 10 miles upstream from Marblemount.

An active fault could cause an earthquake and probably would prevent construction of the dam.

The City Council then told City Light to do additional geologic work to determine if seismic conditjons would prevent construction. But it could not agree whether City Light should continue work on an environmental-impact statement for Copper Creek.

Revelle yesterday agreed with Mayor Royer and Tim Walsh of the City Council staff in recom. mending that environmental work continue. Hildt said "I vote no" because geologic information "strongly indicates that we will not build the dam." 
The Seattle Times

Seattle, Washington

October 20, 1979

\section{Training plan for N-plant inspectors OK'd}

MOSES LAKE - A new ap should not be the only craft trainprenticeship program for qualitycontrol inspectors, most of whon wark at nuclear projects, was afproved yesterday.

The Washington State Apprenticeship \& Training Council approved a program developed by Pasco Local 598, Plumbers Steamfitters, who recently have organized 400 inspectors into the oreanized son inspectors into the union at Hanford and Sotsop.

Before approval could be granted, however, other unions raired jurisdictional questions, contending that the plumbers' union should not be the only craft training inspectors. Boilermakers, clans unions all said they, too, represented inspectors.

Inspectors check work of all cratts at any one construction site.

Ray Mcknight, busines manager of Pasco Jocal 503, resolved the dispute by amending the apprenticeship-request 80 that other programs.

Members of the state agency said that was not the ptace to crafts also could request raining have jurisdictional argumants. In fact, Robert Dilger, ewecutive sec retary of the Washtzgton State Building \& Construction. Trades Council, asked the umions to quit. the dixpute before-the public agen? cy.

Nanied as employer represenpotives on the Jout tabor Mamament Anprenticeshto Committis ior the w o tor wey for

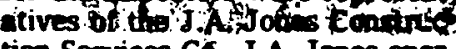
tion Services Co., J.A. Janes enerBy division and Bovee 2 -Erait, ell of Richland; and of the Boecon Corp. of Reviton.
McKnight told other unijonts to go ahead and organitte them. Oth or trades admitted McKnight gol the fump on trying to organive inepectors.

"We won't stand it your way.". he said. He called the argument a "phony jurtsdictional tsoue," canc" ting the tinspectors do not do cro work but document its quallty. the trainitis program to in cotors will be ceprinted from any of the other Local 508 apprentheship programs.and a separate on-the-job and classroom-training curriculum was outlined. 
G SUSAN GILAORE

Trime stefl reperter

Vestem Wushington restdents are concerned about nuclear motes being burled at Hanford, the proposed soa-bed prison near Puydlup, and the state's role in dediding whether an ofl port will built near Pon Angeles.

that was the mescage broadangt to Gov. Dtxy Lee Ray yeaterday as she fielded questions trom th public during a telephone callin how on KIRO Radio.

The radio conference was the int time this year Governor Ray his participated in a live call-in Otradcast.

Ouestions on auclear-waste disfotal and location of the new ptis. on dominated the hourtong show, an. Governot Ray said later that thit teaction was predictable.

Ceveral Puyallup residents were infered over Tuesday's announcement that a 200 -ncre tract of state owned land near Puyallup, known as Red Bluff, and a 560-acre parcel, also near Puyallup, had been selected as the top two choices for the site of a 500 bed medium-secu. rity prison.

The third cholce, selected by the Department of Social and Health Services, is a 320-acre site in Kitsap. County about it miles north of the Tacoma Narrows Bridge.

Construction of the $\$ 3$ million prison was authorized by the Legislature during the last session.

"I wasn't surprised 'we heard trom the people in Puyallup." Governor Ray said after the bradcast. "Wherever (the prison) is built, someone is going 10 object. But it has to be somewhere."

She told callers that they should demand their questions: about se curity and community impact be answered when D.S.H.S. holds public hearings at the three fthalist sites.

"There are no funds in the budget specifically identified as impact," Governor Ray told Gary Weber, a Puyallup resident. "That's a question that should be put toward officials at the hearing."

The criteria in selecting the new prison site rexuired that it be on state-owned land within 50 miles of a city of more than 50,000 west of the Cascade Mountains and east of Hood Canal.

She said a final decision on where the prison will be built should come in about six months.

Governor Ray also assured worried callers, who mentioned the recent disappearance of a patient at Western State Hospital at Stej. lacoom, that the new prison will be built "with safety and security in mind. We learned a great deal over the last year . . ind I know that con be a very deep community concern."

The majority of telephone calls concerned the disposal of nuclear wastes at Hanford, and Governor Ray repeated her support for nuclear energy and her determina. tion to keep Hanford closed to low-level shipments until at least November 6 .

She plans to meet then with the Nuclear Regulatory Commission to examine some of the government's criteria regulating the packaging and shipping of nuclear wastes.

Governor Ray said there is "no hope" the Hanford repository would be reopened before November 6, but she did not say when her closure order may be lifted.

The governor closed the Han. ford site October 4 after three outof-state trucks carrying wastes were found to be in violation of state and federal regulations.

In issuing the proclamation, Govemor Ray said that the site would be shut down until the state has assurance from the N.R.C. that redioactive material coming into the state for disposal is properly packaged and handled.

The state is renegotiating its lease with the Nuclear Engineer ing $\mathrm{Co}_{\text {., }}$ which manages the Hanford storage, and Governor Ray said the new lease will "probably be a little tougher."

Although she wouldn't disciose provisions, she said the lease wil! probably include an increase in the amount Nuclear Engineering pays for disposing the waste it accepts from hospitals, laborato ries and nuclear plants.

Only three areas in the country accept low-level waste - Har ford, Beatty, Nev., and Bamwell, S.C. - and Govemor Ray said Washington charges the lowest rates.

She said Hanford is not a money-making venture for the state, but the new lease will try to staridardize the rates at the three sites.

She said she supports pending congressional legislation that would create about 10 new waste disposal sitzs, and possibly lower the amount trucked into Washingtori State

Governor Ray told callers that Hanford receives about 8,000 tons of iow-level nuclear waste ench yenr from the University of Wash ington and its affiliated hospitals alone, and that 80 to 85 per cent of all low-level waste goes in South Carolina. Of the remaining amount, she said two thirds is buried at Henford.

"The amount of material (buried) is very slight," she said, adding tha! 89 per cent of atl rauliouc. tivity goes into the person and most of the remaining waste from hypodermic needles, bottles, rubber gloves and other surgical materials - will decay.

When asked whether there was any danger of radioactive waste leaking into the nearby Cclumbia River, the governor said that 80 per cent of all wastes decay within the first few months or years of burial, and studies of the migra. tion rate of radionctive materials show it would take 18,000 years before they would reach the $\mathrm{Co}$ lumbia or the water table.

In answer to uther questions:

- Governor Ray assured Nor ma Tumer, an opponent to an Olympic Peninsula oll port, that she would examine whether there is sufficient oil from Alaska to warrent construction of an oil terminal.

- The governor said the state probably won't cut payments to nursing homes. She said a final decision would be announced "in a lew days."

- She repeated her support for President Carter, but hinted she could be ready to support another nominee.

In her weekly television message, aired later yesierday on KIRO, Governor Ray said growth studies conducted by the Departments of Community and Economic Development and Labor and Industries show 17 businesses have made recent commitments to come to Washington State.

$$
\text { C- } 18
$$




\section{Hanford: Still at war, but with new enemy}

RICHLAND, Wash. (AP) - Paul Dunigan cawusto Han ford in 1943 to help make the atornic bombs whičb ended World War II.

He stayed through the Cold War ers of more nuclear plant construction and through the Cold War thaw, when all but one of Hanford's nine reaetors were closed.

Today Dunigan says he is figtiting a different sort of war - a war, he says, against power shortages. As the lingering national argument over nuclear powor continues with its own themes variations, Hanford officials feel that one battle in the energy war will be won when the $\$ 647$ million Fast Flux Test Facility star-s up in late January.

The white-domed Fast Flux is a progenltor of "fast breeder reactors," which produce more fuel than they consume. and produced is plutonium, whicis can be used tc make atomic bombs.

Unlfmited power: The breeder holds the possibllity of virtually unlimited nuclear power and would free the nuclear industry from use of urarium, which is growing more scarce and expensive.

It also attracts some of the fiercest opposition from anti-nuclear people. Not oniy does it present problems of controlling the spread of bomb-grade plutonium, eritics say it carries a potential for catastrophe and contamination much greater than conventional uranium reactors. Government and industry officials consider the Fast Flux the most sophisticated nuclear facility in the porld. They siay its safety systems are totally adequate and dependable.

The Department of Energy plans: to spend $\$ 250$ million in startup, construction and support expensés for the Fast Flux in 1980

$\Lambda$ few miles away from the Fast Flux, Washington Public Power Supply System is building $\$ 5$ billion worth of nuclear pouer plants with the capacity to serve the ncrds of a population five times the size of Seattle.

In another corner of the 570 square miles of sand and sagebrush at Hanforj. miners are toring into a mountain of basalt in scarch of an answer to another question mark which hangs over the nuclear power industry - what to which hangs over

But Ifanford does not have all its energy eges in the But lfanfort
nuclear basket.

I,aboritories: Dunigen, for example, is in charge of a complex of labnratories. He and other scientists are investigating solar. geoihermai, wind, wave and fusion power.

A iarge power piant, furnishing steam to the radioac. live :vaste-management area, burns wood chips in an experiment to see if forest waste can be an economical fuel.

"We re just gelting started," said Dunigan of Hanford's energy role. "The energy business is going to expand."

In cortrast to today's air. of scientific research, in Hanford's early days technicians plunged more or less hlindb into the nuciear age.

They were spurred on by fears that Hitler and the Cermans might develop atomic weapons first.

Dunigan recalls it took an army of about 50,000 construction workers less than two years and $\mathbf{8 3 5 0}$ million to buite the first three reactors - then called "piles" their associated chemical reprocessing plants and 4,000 homes for people disgorged by trainloads on the sleepy farming village which was then Richland.

Those early reactors, built with crossed fingers and incomplete plans, have about as much resemblance to Loday's power producers as a DC-3 has to a Boeing 747, officials say.

Looking back at those war-time reactors, Dunigen said, "If's amazing how well they did, considering how new' technalogy was."

Problems: Even so, the hasty methods of the early days have left a legacy of problems at Hanford.

The most troublesome has been management of radioantive wastes. Hanford has 75 percent of the nation's entire inventory of such waste.

The debate over the handling nuclear wastes flared up in an unrefated way early this month when Gov. Dixy Lee Ray closed a low-level radioactive waste dump operated by a ccmmercial firm at Hanford.

The governor said she took the action not because of faulty operation of the facility, but because arrivin wastes were improperly packaged on two trucks and mechanical defects were found on a third.

In the early days, the attitude was to produce plutonimum for bombs and worry about the wastes later - an attitude that carried through most of the Cold War years.

Highly radioactive wastes were poured into "tempora ry" single-walled storage tanks.

Billions of gallons of iow-radiation wastes were poured into open pools and treoches. Radioactive tritlum is

now leaking into the Columbia River, though

it is so diluted by river water it is not

measurable, officiols say.

And storage tanks have

lealod. The worst was

T106 Tank leak

of 1873 ,

which last 115,000 gallons of liquid waste over a 47 day period.

No one at Hanfond today defends the crude practices of the past, although officials maintain those practices have not, and will not, endanger the public

The Department of Energy is transferring wastes to double-walled tanks, a kind that has never leaked, and solidify ing them as the agency seeks a more permanent disposal solution.

Federal officials are spending more than $\$ 300$ million over the next six years to study Hanford basalts as a permaner

Part of that effort is the Gable Mountain drilling. When the shafts arc completed electric heaters will be installed to simulate effects the heat of decaying nucluar waste has on basalt.

Mooday: A look at attempts to attract more auclear plants to Fanford 


\section{Report says}

\section{Utility lacked}

\section{nuke expertise}

Mew Yort Vimes

WASHINGTON - The Prezident's Commission on the Accident at Three Mile Island bas concluded in its final draft report that the utility that operated the reactor 'did not have sufficient knowledge, expertise and personnel to operate the plant or maintain it adequately."

At the same time, it was learned from two commission members that, because of procedural rules adopted over the weekend, the presidential panel did not adopt a recommendation to halt the construction of new reactors even though the step won the support of a majority of those voting on the question.

The major findings and conclusions of the commission report, a version of which, dated Thursday, Oct. 17, has been obtained by The New York Times, also charged that the government agency responsible for regulating nuclear energy was preoccupled with licensing reactors, not assuring their safety, and lacked an overall system "to measure and Improve the quality of safety regulations."

The recmmendation for a moratorium, the two com. mission members said, was supported in a closed weekend meeting by six commlssioners and opposed by three or four. The same number supported a moratorium last wóek.

But the proposal did not become a formal recommendation because of a rule adopted last Saturday that such recommendations would require an absolute majority of seven of the 12 commissioners. The rule, the two commissioners said, was proposed by the chairmat of the commission, John G. Kemeny.

Barbara Jorgenson, the commission's director of publlc relatons, did not deny that the moratorium proposal had not been approved even though supported by a majority of those voting. But. she aaid that the debate within the commission had been highly complicated and "a serious injustice" might be done the commission and Individual commissioners if the story about the moratorlum vote was told without reading the full transcript of the commission debate.

The final meetings of the commission, which is scheduled to submit its report to President Carter early next week, have been closed to the public, and the transcripts will not be available for some time. 


\section{'Safe' radiation level defies consensus view}

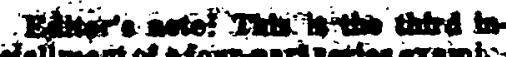

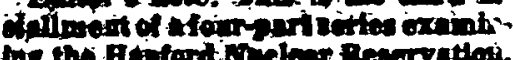
he end Adaford melem Peaprittog. Tho articles roce witteng Tricly

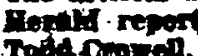

Rigitind; printip) - Gary Carto belleves Eanfond boulth regulatton in a so striet, cunburas are a Treat radiation probrian to Hanford Jreat r radiation probria to Hanfor re me matarials.

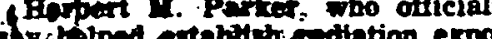

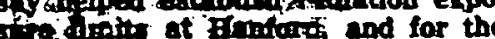
Het nureben hdintry, now ways th fo nits shonid be rediced tenald.

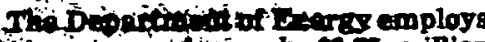

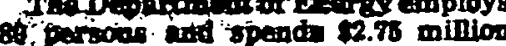
8. prilly to protoct tha keinth of Harcond ton proty

That - millian thit has been spent over the past 14 theat has been spent over the past 1 . years

Despite this expenditire, research ers can't agree whesher low-level ers can't agree wheher low-low
rediation barms nuclear wortkers.

rediation harms nuclear worters.

There is considerable debate among scientists whether there is any safe level of ebsorption - and over the cafety of repeated low doses of radja-
tion. Nuclear critics point so a 1976 Department of Energy stidy made by Thome Mancuso-which claimed to show Hanford workers suffered highe than normal cancer deaths. Other experts disputed his findings. Mancuso studied Hanford health statistics from 1884 to 1876.

A White House task force recently recommended that to improve crediblitty, future radiation bealth re search should be done by a government egency other than the Energy Departmeat.
Carter, a Battelle Northwest Labo ratories senibr technician. has been working ince 1962 with radiation a Ranford.

"We're prcbably overprotected because they're (Energy Department) trying to eliminate any possibility of to us or the public," Carter says.

Farker, a Battelle consu.tant, says that with a fe'w exceptions te favors a tenfold reduction in the amount of radiation a worber can receive annually.

The govermment limit, devised by Parker, is five rems annual y.

A rem is the standard unit of measurement of asjrbed radiation in living tissue, adjusted for differert kinds of radiation so that sne rem of any radiation will produce the same biologica ffeet.

A tenfold reiluction would establish limit of $0.5 \mathrm{rem}$

A person receives .02 to $.03 \mathrm{rem}$ in cormal chest $X$-ray.

Each American, on average, recelves 0.1 to 0.2 rem of radiation a cear from catural "baciground" sources such as cosmic rays and manmage dragostic $X$ rays.

Hanford contractors today roluntariy limit workers to a max mum of three rems.

A top Hanford orficial says a tenfold reduction would seriously hamper operations at Hanfued and would shut town many nuclear power reactors in the country, including the $N$ Reactor and many other plants at Hanford.

Parker says his old arbitrary for mula was estabished at a tine when be and others ware too ortimistic about the effects o: radiation.

"I'm not happy with that. If you us: a (National Academy of Sciences) standard with my formula you would have a 30 percent increase in a person's cancer risk.

"I would not want to recommend that to a worker."

Of the 6,928 emplcyees who worked in radiation areas, two received three and four rems, and none got more than four.

Of the rest, eight percent. or 527, received 1 to 2 rems. Three percent. or 231 , received two to threc rems. The rest (89 percent) received one rem or less.

Jerry Yesberger, a Hanford health hysicist, says Hanford's hea!th record is one of the finest in the indusreceived radiation injuries.

In 1965 a man losi the tips of two fingers after overexposure from an ? ray machine.

On Aug. 30, 1976, Harold MicCluskey was injured in a chemical explocion the $Z$ plant. It was considered the worst contamination accident in $\mathrm{L}$.S nuclear history.

Today, nearly three vears after the acciden: Mechliskey rarries radiation ceveral hundred limes what is usually "onsidered "safe."

HClustey's surviring such a mas sive dost: for so long without showing igns of sucil rommun radjation illnesses its cancer or loss of hair night be iutgrpreted as Gre indication that radiation is not as lethal as is popularly believed.

fit Mccluskey was b4 at the time of the acc:den!. and it may be he was ton wid tin chevilup cancers that some scientusts beicve are radialion Breitent vironmental Health Fcundation.

Yesherger says ordy 16 workers since 1944 have rereived radiation exposures above tinc three rem limit now imposed thmits were not as strict in earlier days).

An adritiona: :even have some small part ot thar budy expused to racistion above the limit.

The Hanford foundation russ the Emergency Decontamination Facility built alsout 10 zeai's ago in Richland When a workur with no previous expe rience in radiation conses to Itanford he receives a course in radiation pro tection

When he gees on the job, one radiation monitor is stalioned with every five workers.

Each worker must wear a dosime ter badge and a "self-reading" pencil both of wich monitor radiation.

The pencil records the amount re reived during the day. The amount is recorded in a daily log book

When workers go into high radiation zones, they take a large monitor that beeps when they've rzeeived thei mit.

Each worker must have a physical examination $b$ fore being employed a Hanford, and they must have annual Examinations.

When leaving radiation zones, workers must be "checked out" on machines which shrw radiation on feet and insends. In addition. the boay is surveyed hy a hind-ateld counter.

rrotertive ciotneng is worn appropriate to the level of radiation expectcu. In tigh radialisn zones a worker is covered teati-to-10ot with several layers of ciothing.

Wednesday: The non-nuclear side of Hanford. 
The Seattle Times

Seattle, Washington

October 24, 1979

\section{Nuclear dump in \\ Nevada} stays closed

CARSON CITY, Nev. - (UPI) - Gov. Robert List says he is going ahead with his order closing a nuclear dump in Nevada despite mounting pleas from hospitals and research centers across the nation to keep it open.

"Nevada is a gambiing state but I'm not taking a gamble with our citizens," List said yesterday.

The governor criticised President Carter, saying he was more interested in politics than in developing a national policy for the disposal of nuclear garbage.

George Kolbenschlag, assistant to the president for the Nuclear Engtneering $\mathrm{Co}$, which operates the dump, said the shutdown could limit such things as cancer research.

List, who is Western chairman of the American Cancer Society, said he knew the valuc of using radiation in treating the disease.

"The calls and letters coming in here are from legitimate organiza. tions who are legitimately concermed as to what it is going to do with cancer therapy and research," he said.

"What they are going to do is to turn their wrath on Washington to see that this proble:n is id. dressed." 
The Seattle Times

Seattle, Washington

October 24, 1979

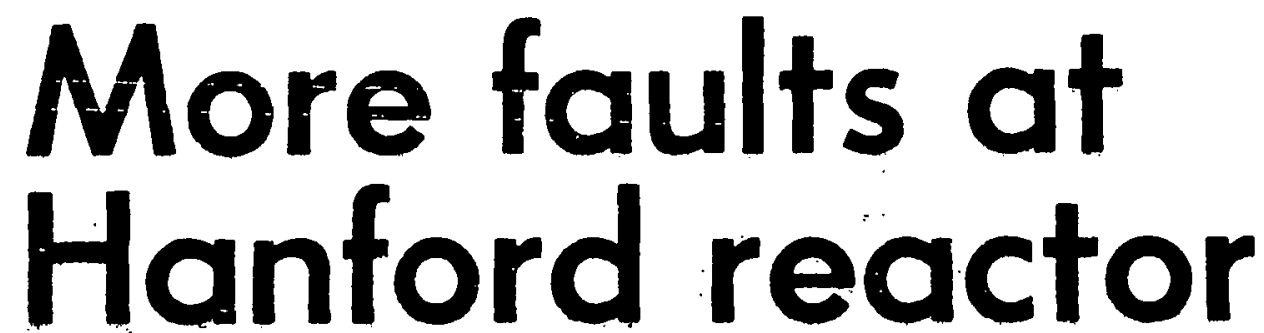

RICHLAND - (AP) - Be tween 10 per cent and 40 per cent of the welds on the 1,000-ton sacrificial shield around the reactor at the Hanford No. 2 nuclear power plant are "visually defective," the Nuclear Regulatory Commission says.

Some welds are missing on the reactor, which is under construction.

The defects were discovered five months ago and an inspection is still under way, but the extent of the problem was revealed this week.

Voids were found in what was supposed to be the 2-foot-thick solid concrete center of the shield, and water was found accumulat ing in the concrete, said R.F. Nowakowski, a spokesman for the Washington Public Power Supply System, which is building the plant.

Documentation is alco missing on the 2-inch steel which encases the concrete, he added.

It will take at least another month to complete the inspection, determine the type and cost of repairs and estimate delay time. Nowakowski said. The $\$ 8$ million sacrificial shield, built by the Leckenby Co. of Seattle, was com. pleted two years ago

The project manager, Art Kohler, said, "We anticipate the ourcome of the engineering review now under way will be that the flaws are tolerable; that they won't weaken the vessel."

But the N.R.C. would have to approve, and a commission inspector, Tom Bishop, said that as the reactor now sits it cmild not be licensed.

Kohler said it is possible that during startup instruments could be placed outside the sacrificial shield to see where voids might be allowing radiation through. Possibly leaks could be stopped with patches on the outside of the shield, he said.

The biggest problem will be adding the missing welds, Kohler said.

"I knew they were going to have trouble," a former Leckenby employe said.

He said he told officials "they weren't building a tank in the boondocks. That this iwas critical work."

The former employe said that when he rejected some welds the company tired him and "brought in someone to highball the job."

David Paup, Leckenby con. struction manager, sald. "We did precisely what the engineer, the owner and our contract indicated. We wouldn't highball a project like this."

The No. 2 site has been plagued by problems since construction started in 1972 . It will cost about \& million to repair incorrectly installed pipe hangers. Two years and $\$ 2.25$ million worth of mepairs are nearly complete on faulty welds on beams attached to the shield.

Although the power system has vowed to hold contractors liable for faulty work, much of the work was done by subcontractors to Bovee-Crail, whose contract on No. 2 was canceled by the system and with whom the utillty is now in multimiltion-dollar litigation. 
The Spokesman-Review

Spokane, Washington

October 24, 1979

\section{Hanford's shield defective}

RICHLAND, Wash. (AP) - Serious defects have been found in the massive con crete and steel shield around the reactor at the Hanford No. 2 nuclear power plant, Washington Public cials confirmed Tuesday.

Although the defects were discovered about flve months ago and an inspection has been under way since, the probable extent of the problem was not released until this week, ex. plained WPPSS spokesman B.F. Nowatowsti.

Between 10 and 40 percent of the wolds on the 1,000 ton socrificial shield are "visu. ally defective" and "vis reld are mising some wether the Nuclear al to gother, the Nuclear Regula ory Commission reported. Voids have been found in what was supposed to bethe two-coot thick solid coacrete center of the shield. Water was lound ponding in the concrote, Nowakowski confirmed.

In addition, documenta tion on the two-inch steel which encases the concrete is missing.

Nowakowshi said it will take another month to complete the inspection, detarmine the type and cost of repairs and estimate delay time.

The eacrificial shleld was completed two years ago, under an $\$ 8,384,000$ contract it could not be licensed.

with Leckenby Co. of Seat-

Kohler said it's possible

He said the welding was bad, but when he rejected

Repairs $\rightarrow$ ill be complicated because the reactor vessel now sits inside the that during startup, now som of the welds. the go ments could be placed out someone to hiphball the side the sacrificial shield to job." is in - see where voids might be side a containment vessel. There containment vessel. work David Paup, Leckenby construction manager co firm unas unare of any could then be could then be stopped with problems. We did precisereactor and shield. But A.rt Kohler, project side of the shield, he said. manager, said he doesn't mect the waid he project side or the to be the welds will have br The biggest problem will ly what the engineer, the owner and our cont ract indicated. We wouldn thighbal a project like this. We pride welds, Kohler said ves on being a compupate the outcome of the gineericg review now under One man tent contractor." way will be that the naws was built, said, "I knew are tolerable; that they they were going to have won't weaken the vessel." trouble." He claimed he told But tie NRC would have Leckenby officials, "that to approve of that, and NRC they weren't building a tank inspector Tom Bishop said in the boondocks. That this that as the reactor now bits, was critical work." 


\section{HANFORD}

\section{Unique energy role cited}

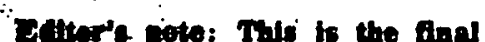
cotailneiat of a certes examinter Su Angiond Nuclear Reservation.

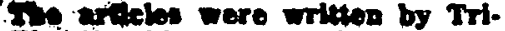
Qt Eerall veporters Jlm Dulleaty ind Ion Crovelu

TrohllaND Wash. (AP) - There 7 noo-aucloar stde to Hanford 4.î makes people like KIrk Prranlinar comedinos feed lits the A min out

Iis Eitiolto Ninthreet Laborato. sidentit is in charge of solor tresty moseareh at the 570-square info finnford nuclear reservation.

inniord lans cidres of selentiats riopidag os problems of nuclear toper, to bagure, but many also are A wort on alternative energy - Sicieen.

Int Aujunt Sen. Warren Magmu. on, D-Fill, sald be wants to see tonfiond become a regional energy cinter, not only for nuclear plants but for soler, wind, Bynthetic fuel, coal and gasohol production.

Hanford and the Tri-Cities "have a unlquely important role to play in our region's energy future," said Magnuson, chairman of the Senate Appropriations Committee, in speech to the Tri-City Nuclear Industrial Council.

"You have a combination of facillties and talent," Locluding experience with nuclear energy, semiisolation, broad public support and strong federal support, the senator said.

In all, the Department of Energy, which runs faniord, will spend about $\$ 70$ million there in fiscal 1880 on non-nuclear research. The total Henford budget is about $8666 \mathrm{mil}$. lion.

Drumbeller's 87.5 million budget includes research into renewal sources of energy such as wind, colar and forest wastes.

This figure may seem small, but only fow years aro it was a flat nothing, be said.

Hanford scientists are working on ways to improve solar collectors and on more efficient ways to produce energy from solar cells. which convert sunlight directly into electricity.

Scientists also are working on now ways to make syntbetic fuels from wood chips at costs they hope will be comparahie to foreign oil.

The Energy Department is experimenting with wood pellets, rather than conl, for Hanford boilers.

Hanford could be the largest industrial user of wood waste in the inland Pacific Northwest, officials say.

Hanford also is the site for a (Continued on page 8)

\section{Hanford}

proposed 890 million laboratory th test materials golng tnto future tudon power plants.

Drumbeller saye Hanford it a rocid place for research into alterandve fuels becauge of its abundant sulight, access to agricultural and loplist produrte and colleation of eneros expertis.

The ruy who is worldn on, eny, - hat taboler proputes in auclear Atrirgy is instantiy transierable to ifinllar lind of solar work," he said.

inher scientists investigating ponalble health pre blems of current energy practices.

Iin' Bettalle Isboratory, for exainple, is part of a network in the Uwitd Etates collocting and analyz ing date on "acte rinta", a form of ectuptiog caused by chemical reafont of sulfur and nitrogen oxides In the atomosphere.

s. Others have been studying the nological effects of large eleotrical t jhit on apimals, trying to dircover i) very high voltage power. Ines atrht be a health hazard

There are others at Hanford mare ooncerned with geese than getser oonnters, with plants rather than Flutonium and with saimon and teelhead rather than onielding homend suclenr reactors.

Whe reapers, of which only one - N Rentor, is in operation today the tis' comile-long Hanford
Rearh, a strotch of the Culumbla Rlver above Richland.

It is prized by environmentalists as the last free-lowing part of the Columbia - long closed for security reasons, it was recently opened to the public, though boaters are still pivlibited trom lending at Hanford - and 85 a unique wildife refuge.

This stretch supports one of the river's largest spawning grounds for steelhead and salmon.

It is also a protected breeding area for wild veese, ducks, eagles and mule deer.

Some scientists are studying the bebavior of the great blue heron which neats on the reservation, and the effects of potential radiation or pesticide contamination.

Mast of the animals hove access to swemps, ponds and trenches at Hanford where low-level radioac tive wastes have been disposed. Sclentists at Battelle regularly inte samples of all species.

In come cases, measurable amounts of radiation are found in the animals - although in quantities too low to harm man if the animals were lllled and eaten, the scientists say.

While hunting on the reservation is prohibited, several of the animals are game apecies and travel to other areas.

Hanford has been the subject of a stange-bedfellows alliance between the local Sierra Club and the strongly pro-nuclear Tri-City nuclear council.

Both have been fighting the proposed Ben Franklin Dam.

The Interior depertment says it would destroy much of Hanford's wildlife. The Army Corps of Bngineers and other proponents say a dam is needed to produce power.

The Sierra Club opposes the en. vironmental damage the dam would cause. The nuclear council fears that rising ground waters might make Hanford less desirable as a future energy park.

The dam would food the old Han. ford reactors and 60 radioactively contaminated areas of the reserva tion. This could result in increased radionativity in the Columbia, $B$ ultelle scientists said in a report prepared for the Energy Department.

Despite its support of the atom, the nuclear council has long been aware of Hanford's unhealthy re. lance an one industry and bas Bought ways to diversity the economy of the Tri-Cities of Richland, Kennewick and Pasco.

It was largely through the council's work that Hanford, unique among the operations created by the World War II atomic bomb project, today hosts a variety of private companies rather than a Bingle contractor. 


\section{States will be asked to provide nuclear waste dumps}

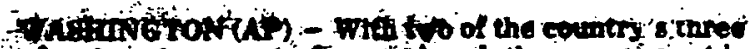
los Icvel nuclenr waste firmos toced, the govertiont is rinining to ask poiveors to provide temporary storace dives far radionctive waste produced in their own states. oficiale eald Thuredey.

Thut could mein etindishment of tomporory storase ates in at leat a dosen statis in hich renrly 70 percent of the country' low-level nuclear waste is produced.

af the country's low-lovel suclear waste is produced. the tareo U.S, sites for disposal of nuclear waste ware closed this month. A dump in Washington state was closed becance inproperty packaged wastes were betng delvered to the sich. Autother site, in Nevoda, was closed after radipactho wasto was discovered outside dump boundartes.

The third aite, in South Carolina, remcined open Thursday, but officiais sald none of the wastes that would normally so to Noverda or Washiogton could be sent there.
\end{abstract}

Government officials and spokesmen for the medical community have sald hospitals; research facilities and some sucbar-power plionts will face serious problems within weelo because they will have nowhere to ship their radiosctive wiastes.

In an attempt to bead that problem, the Nuclear Regulatory Commisaion and the Energy Department will urge governors in the states where the wastes are produced to facilities, administratton officials gaid.

Asked how hard the NRC would push the governors to adopt such a plan, NRC spokeeman Frank lìgram said:

To the extent that we can. We can't onder them to do it." Richard Cunningham, whose NRC office licenses oper ations that produce low-level nuclear wastes, said the proposal to get states to provide temporary storage was federal officials and others involved in the issue.

A spokesman for the National Governor's Assaciation, which also had a represenative at the neeting, said such a plan was sure to provoke controversy and that some governors and state legislators would oppose it.

"We recognize the wastes have to be put somewhere, but you can't leave it up to the 50 governors," said Joe McLaughlin of the governor's association.

Meanwhile Govs Dixy Lee Ray of Washington and Robert List of Nevada were described by federal officials as remaining adament in treeping the waste dumps in as remaining adament in keeping lhe waste dumps in

South Carolin Gov. Dick Riloy, who barred any of the

South Carolina Gov. Dick Riley, who barred any of the wastes from being diverted from Washington and Nevada to his state, said the amount of material now movid

Among those who attended Wednesday's meeting were Among those who attended Wednesday's meeting were representatives of the NRC, the Energy Department, the sociaton, the Society of Nuclear Medicine, and the goversociaton, the Societ

The group, according to Cunningham, also discussed the possibility of opening federal torage siter to numer cial use. But ore Energy Department sourc if id the department end the NRC prefer storage of the dates in the states where they are produced.

Low-level radioactive wastes are renen to inot every state, with the largest amounte anodin. nia, minois and the Northeast - where thet anteos trations of hospitals, research facilities and nuclear pow er stations.

A 1978 government survey. howed that 12 . produced nearly 70 percent of the byproducts from nuclear power. otations as inj

The 12 states producher the mat wistes an percentege of the produch the moyt wartes aft of York, Californis and nlinois 8 percen produces ar 1 . and Callornia and minois, 8 perceat ench; Peand honila and North Carolina, 7 percent each; South Cayolina, percent, Florida S percent; and Nes Jersey, Cann petsent 